Botanical Evidence of

Floods and Flood-Plain

Deposition

GEOLOGICAL SURVEY PROFESSIONAL PAPER 485-A

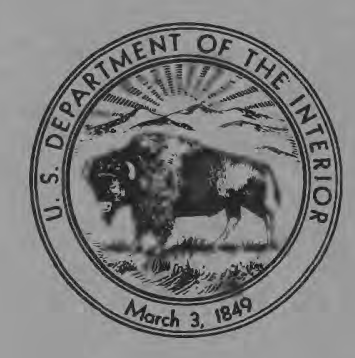




\section{Botanical Evidence of}

\section{Floods and Flood-Plain}

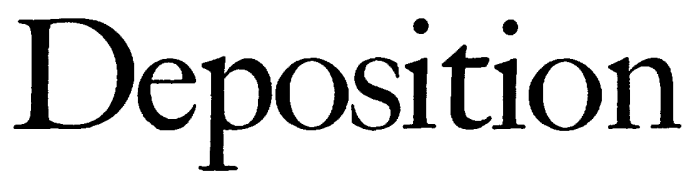

By ROBERT S. SIGAFOOS

VEGETATION A N D H Y D OLOGIC PHENOMENA

GEOLOGICAL SURVEY PROFESIONAL PAPER 485-A A description of botanical methods used to determine dates and occurrences of floods and deposition of sediment on modern flood plains

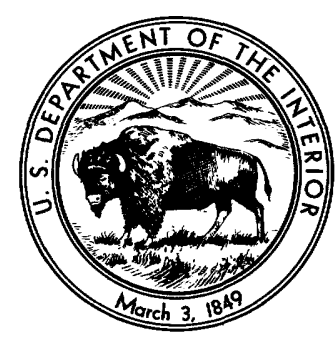


UNITED STATES DEPARTMENT OF THE INTERIOR

STEWART L. UDALL, Secretary

GEOLOGICAL SURVEY

Thomas B. Nolan, Director

The U.S. Geological Survey Library has cataloged this publication as follows :

Sigafoos, Robert Sumner, 1920-

Botanical evidence of floods and flood-plain deposition. Washington, U.S. Govt. Print. Off., 1964.

vi, 35 p. illus., map, diagrs. $30 \mathrm{~cm}$. (U.S. Geological Survey. Professional Paper 485-A.)

Vegetation and hydrologic phenomena.

Bibliography : p. 34-35.

1. Sedimentation and deposition. 2. Floods. I. Title. (Series)

For sale by the Superintendent of Documents, U.S. Government Printing Office Washington, D.C., 20402 - Price 35 cents 


\section{CONTENTS}

Glossary

Abstract. .

Introduction.

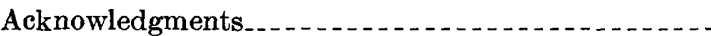

Mechanism of plant growth

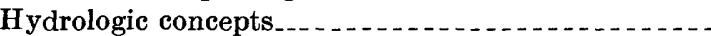

Collection of streamflow records

Comparison of floods.

Floodstage-discharge realtionship _...........

Effects of floods upon trees...........

Physical effects of high velocity and debris

Effects of inundation upon trees.

Growth of trees after flood damage..................

Circumferential growth around trunk scars........

Growth of sprouts from stumps and water-felled trees.

Growth of trees following burial by alluvium during

floods -

Analysis of structure of wood from buried trunk.
Page

V

A 1

1

2

2

4

4

6

9

8

20
Growth of trees after flood damage-Continued

Evidence of floods and deposition in trees along small streams.

Evidence of sequential deposition and erosion on the flood plain .

Botanical phenomena relating to the formation of the flood plain.

Relationship between flood-plain trees and low flow

Significance of old trees on banks.

Botanical evidence of current processes affecting the flood plain . Economic significance of botanical evidence of floods..- -

Value of botanical evidence of floods and flood-plain deposition. ...

List of plants.

References cited

Page A23

\section{ILLUSTRATIONS}

Figure 1. Map of Potomac River near Washington, D.C.

Sprouts that strated to grow from ash stem after

3. View of flood-plain forest showing form of trees

4. Floating ice overriding flood plain scars trees.

5. Ice jam on Potomac River, Washington, D.C., February 16, 1948

6. Potomac River, low flow, Washington, D.C. July 1956

7. Diagrams representing circumferential growth of trunk

8. Parts of a stem of an ash tree damaged by minor ice jam on January 15, 1958

9. Fragments of ice deposited on flood plain of Potomac River on January 15, 1958

10. Cross sections through stem of damaged ash tree shown in figure 8

11. Potomac River in flood on August 20, 1955

12. Potomac River at low flow, June 1956

13. Sprouts from stump cut off by an ice jam on February 16,1948

14. Vertical sprout growing from inclined trunk that was felled by 1948 ice jam.

15. Trunk of tree suggesting origin as a sprout which started to grow in 1861

16. Ash sprouts of four ages growing from a stump

17. Diagrams showing events that produced the form of the ash tree illustrated in figure 16

18. Diagram of tree bases postulated as result of different rates of deposition

19. Ash tree part_y uprooted prior to growing season of 1936 and subsequently buried.

20. Inclined buried ash tree.

21. Drawing showing basal sprout, location of samples, and approximate level of flood plain prior to 1936 . . . -

22. Photomicrograph of wood from buried trunk of ash tree

23. Ratio of difference between mean of early wood and late wood vessel diameters to the mean of early wood vessel diameters.

24. Scar on channel side of river birch on Difficult Run, Va

25. Alder sprout growing from parent stem knocked over in 1956, Scott Run, Va.

26. Ash sprout growing from inclined trunk knocked over prior to 1928, Scott Run, Va.

27. Ash from flood plain, Tripps Run, Va., showing flood-damage form

28. Drawing of buried part of ash tree in figure 19

29. Ash tree knocked over by one flood, partly buried by another, and exposed by a third......

30. Silver maple trees on bank flooded at least 60 times between 1931 and 1960

31. Diagrams representing establishment of trees on flood plain

32. Cut bank of Potomac River showing newly exposed roots and recently fallen trees.

Page 


\section{GLOSSARY}

Annual ring.-A layer of wood resulting from one season's growth of a tree; appears as a ring when seen in a cross section of a tree trunk.

Apical dominance. - The inhibiting effect of hormones produced in buds at the apex of a stem which, as long as this growing tip remains intact, prevents the development of buds farther down on the stem.

Bark.-A general term for the tissues outside the vascular cambium in tree trunks and stems.

Callus.-A tissue of thin-walled cells that grows over a scar.

Cambium.-A layer of meristematic cells which by dividing forms new tissues. Vascular cambium divides, producing xylem toward inside and phloem toward outside beneath bark in woody plants. Cork cambium lies outside the phloem and produces layers of cork that constitute most of the outer bark.

Coniferous trees.- Trees that produce naked seeds in cones, as opposed to fruits, and are typically needleleaved evergreens. Pine, hemlock, and Douglas-fir are examples.

Crest.-The highest elevation of a flood.

Deciduous trees.-Trees whose leaves turn brown and die or fall in the autumn. Baldcypress (Taxodium distichum) and larch (Larix laricina) are examples of deciduous coniferous trees.

Diff use porous.-Wood in which vessels are all about the same size across an annual ring, as in maple or birch.

Discharge.-In this report, discharge refers to the amount of flow in a stream or river. It is measured in cubic feet per second (cfs). One cfs is equivalent to 7.48 gallons per second, about 646,000 gallons per day, or 28.32 liters per second.

Evergreen trees.-Trees that retain green leaves all winter. Live oak (Quercus virginiana) and American holly (Ilex opaca) are examples of broad-leaved, evergreen trees. Most coniferous trees are evergreen.

Flood.-Any flow of a stream or river that overtops the banks of the channel and spreads across the flood plain.

Flood damage.-Generally considered to mean the economic loss resulting from floods. In this report, the physical effects of floods upon trees and other plants are also considered as flood damage.

Growth.-The process of adding new cells or cellular material by the conversion of organic and inorganic materials.

Growth increment.-The amount of new material added as a result of growth. One season's increment is the annual increment, which approaches the shape of a hollow cone in a tree trunk.

Hardwood trees.-A general term, used mostly in the lumber industry, referring to broad-leaved deciduous trees. Wood of some hardwood trees is softer than that of some softwood trees.

Hormone.-A substance, produced in a plant, that influences specific physiological processes and is often called a growth regulator.

Meristem.--Living tissue in which new cells form by division and grow by the addition of synthesized protoplasm. Vascular cambium is a lateral meristem.

Parenchyma.-Tissue composed of thin-walled, nearly spherical cells. Pith in the center of corn cobs is parenchyma.

Peak.-The highest discharge attained during a flood. Crest and peak stage are synonomous. Peak pertains also to the maximum discharge.

Phloem.-Food-conducting tissue of most plants; forms on outside of vascular cambium and constitutes most of inner bark.

Pith.-Tissue in the center of stems composed of a mass of parenchyma cells.

Rays.-A layer of cells extending radially in the wood and inner bark of tree trunks.

Ring-porous.-Wood in which vessels in earlywood are larger than those in latewood, as in a hickory or oak.

Root.-As used in this report, the underground parts of plants on which, as opposed to stems, there are no buds, leaves, or leaf scars. Most roots of woody plants do not have pith in the center. 
Sedimentation.-The complete series of processes that includes the removal of particles from bedrock, their transportation, deposition, and consolidation as another rock.

Softwood trees.-A general term used mostly in lumber industry referring to coniferous trees. Wood of some softwood trees is harder than that of some hardwood trees.

Stage.-The elevation of the surface of a body of water.

Stem.-Plant organ which has buds, leaves, or leaf scars. Most stems grow above ground, but some are subterranean.

Streamflow.-Flow of water, or discharge, in a natural channel.

Tissue.-Group of cells that have a similar structure or function or both.

Trunk.-A general term referring to a large, single, woody stem of a tree.

Vessels.-Specialized tissue in wood or xylem of plants, consisting of cells of different shape and size in different species. Vessel cells are alined vertically, and end walls are absent or are perforated by holes or slits. Water or sap flows in vessels.

Xylem.-Water-conducting tissue of most plants and supporting tissue (wood) of trees. Develops from cells formed toward inside of cambium. 


\title{
BOTANIGAL EVIDENCE OF FLOODS AND FLOOD-PLAIN DEPOSITION
}

\author{
By Robert S. Sigafoos
}

\begin{abstract}
Methods of identifying past floods have been developed from a study of the form and age of parts of trees growing on the flood plain of the Potomac River near Washington, D.C. The date of deposition of sediment can be learned from the study of the structure of wood in the buried part of twee trunks, and the approximate thickness of the deposit can be determined by measuring to the level of the original tree base. Anatomical characteristics of the wood of roots exposed by erosion of the banks and the flood plain provide data for ascertaining the year that the roots were first exposed. The methods can be used to determine the occurrence of floods and flood-plain deposition on streams draining areas at least as small as 4 square miles.

The establishment and maturation of trees on a flood plain are the result of an interrelated sequence in the timing of seed dissemination and germination, suitable environmental conditions, and the flow regime of the river. The channelward limit of perennial woody plants-tree species in the humid Eastern United States-represents either the level of the maximum discharge during extended periods of low flow or the edge of the channel that is encroaching on a flood plain as the result of lateral corrasion. This line, separating the flood-plain forest from the channel, can be regarded as the bank of the river or the channelward limit of the flood plain, because it is related to the complete range of river discharges and can be readily seen and mapped.

Erosion and deposition on densely tree-covered surfaces away from the bank are characteristic processes and thus are effective in the formation and modification of flood plains in the humid Eastern United States. Although evidence of lateral corrosion and accretion has been found along the Potomac River, the presence of many old trees on the vertical face of banks indicates that some banks have been stable for more than 100 years. The botanical evidence shows that on forested flood plains, certainly on those of rivers which are moving laterally only slowly, alluvium is interchanged rapidly by local erosion during overbank fiows and by subsequent deposition either during the same flood or during following floods. This process of vertical trading of flood-plain sediments without intervention of channel movement may affect large amounts of material.

In the absence of streamflow data, engineers must rely on indirect methods of analysis to determine the magnitude and frequency of floods. Like most hydrologic data, these analyses are strange to many who are directly concerned with floodplain phenomena. Evidence of floods and flood-plain deposition as seen in trees is easy to comprehend and presents an
\end{abstract}

irrefutable record of past floods. The methods can be used, therefore, along reaches for which no discharge records exist. Because the methods have proved to be valid on small streams for which streamflow data are inadequate or nonexistent, they can be of help in planning flood-plain use in expanding cities. The age and form of flood-damaged trees may provide the date of the minimum stage of a flood that occurred prior to the period of record. The botanical phenomena will, at least, indicate the year in which a severe flood occurred, thereby providing valuable assistance in a further search for other kinds of evidence.

\section{INTRODUCTION}

The growth and form of trees along rivers permit the dating of flood occurrences in the last 100 years and the dating of deposition of sediment on flood plains. Floods scar the bark, prune the tops and branches, or knock over or destroy most of the trees on the flood plain. Most trees, however, are not killed; new wood and bark grow over the scars, and sprouts grow from decapitated branches and inclined trunks. The trees continue to grow. The number of annual rings that have grown since scarring of the bark or the age of the sprouts is equal to the number of growing seasons that have elapsed since the trees were damaged. The year when the flood occurred, therefore, can be ascertained.

Some trees are partly buried by deposition of sediment, but only a few are killed. If a tree survives partial burial, the new wood formed in the buried part of the trunk is more like root wood than like stem wood; thus it is possible to date the year of burial. The surface upon which the trees were growing prior to burial can be identified by digging to the roots growing from the flared base of the trunk; thus the approximate depth of alluvium that has been deposited can be measured.

Floods are characteristic of nearly all rivers; and although severe floods have been recorded, measured, and mapped in recent years, they occur unnoticed or are soon forgotten by most people. A flood is any flow of a stream or river that overtops the banks of the channel and spreads across the flood plain. On the average, 
flows of this size or larger occur about once every 2 years (Hoyt and Langbein, 1955, p. 15). Flood-control problems are discussed in a recent comprehensive book by Leopold and Maddock (1954).

The purpose of this report is to demonstrate, by examples drawn principally from work in progress in the Potomac River basin, how botanical evidence can be used to deduce information on floods and flood-plain deposition. The examples used are important to this report only to the degree that they facilitate the illustration of methodology. The larger study, concerned with the relationship of vegetation to the hydrology of streams, has been confined largely to the Potomac River flood plain in the vicinity of Washington, D.C. (Fig. 1), primarily because of the long record of streamflow available for this reach. From a study of trees, the flood history of a reach can be extended in time prior to the period of the streamflow record, or a history can be reconstructed for reaches for which there are no records. The depth of fluvial sediment can be measured, and the period of time since deposition can be determined; consequently, the botanical evidence will aid in distinguishing between flood plains and terraces.

\section{ACKNOWLEDGMENTS}

During the course of this study, many of the author's colleagues visited the study areas and offered invaluable encouragement and suggestions. Thanks are given to personnel of Region 6, National Park Service-

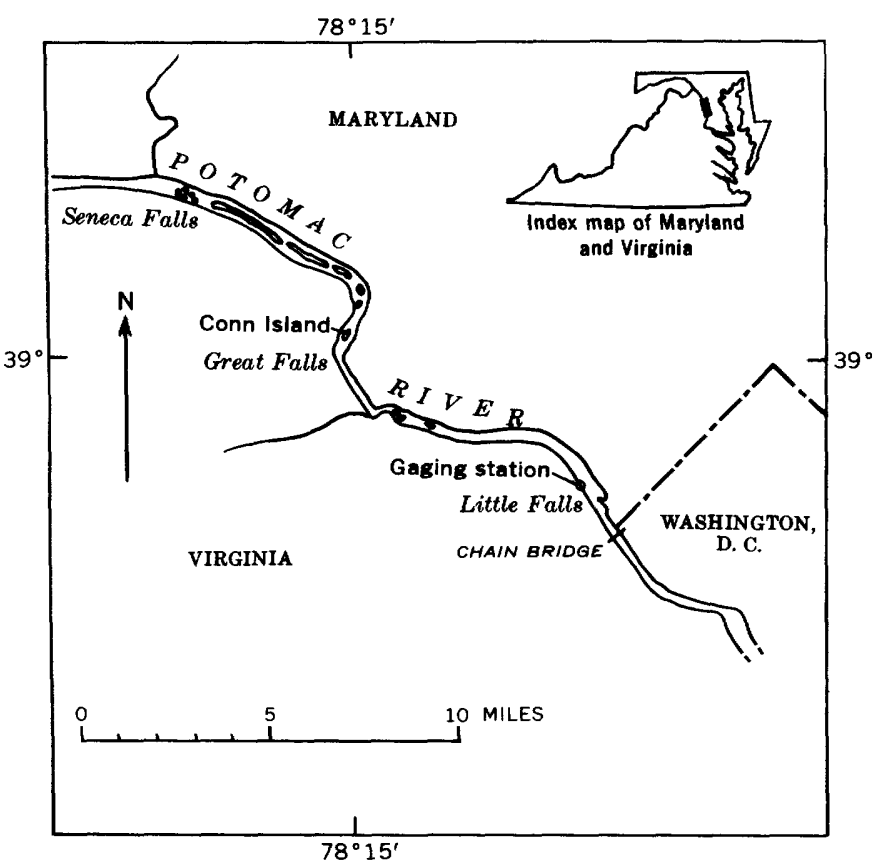

Froure 1.-Map of part of Potomac River near Washington, D.C., showing study area. Base from Washington and Baltimore $1: 250,000$ quadrangles. especially to W. Drew Chick, Jr., and T. Sutton Jettfor permission to make studies in the Chesapeake and Ohio Canal and Palisades Parks, and to Maurice Sullivan for help and suggestions resulting from visits to the field areas. Joe Brown and James Watt, Fairfax County Park Authority, were most helpful with phases of the study at Great Falls Park, Va., and they recently provided a canoe and other facilities at River View Park. Without the permission and enthusiastic interest of several persons who own land along the Potomac River, this study would not have been possible. These include S. P. Spalding, O. V. Carper, Misses Olga A. Larsgaard and Doris K. Stevenson, H. D. Weant, the staff of Madeira School, and E. B. Burling. The author also wishes to thank Ethel W. Coffay, W. J. Conover, and N. C. Matalas for help in making the statistical analysis of vessel diameters.

\section{MECHANISM OF PLANT GROWTH}

Trees grow in height as a result of the division of a few cells just below the tip of each twig. These cells retain the ability to divide, and the tissue is called the apical meristem. Toward the base of the tree, just below the expanding tip and essentially continuous with the apical meristem, is the vascular cambium, which extends as a cylinder down the trunk to near the tips of the roots. This tissue also is meristematic, having the ability to divide, whereby cells formed to the outside differentiate into phloem, or part of the bark; and cells formed inside the tissue differentiate into xylem, or wood.

Growth activity of the vascular cambium probably begins at about the time that apical growth starts in the spring, and the activity proceeds downward in the trunk and into the roots. Trees increase in diamater in a general way rather rapidly in early spring; their growth slows later in the season and ceases near the end of the summer. The wood formed early in the growing season is different structurally from that formed later in the summer. Because a different kind of wood, here called early wood, is produced outside the late wood formed at the end of the previous summer, a distinct line is formed between wood that marks the end of one growing season and wood that marks the start of another. The concentric cylinders of wood between successive lines are quite distinct in cross sections of most trees and are known as annual rings. Rings seen in the cross sections of small branches and twigs of some trees, on the other hand, are not formed annually (Glock and others, 1960).

Growth activity and anatomy are less well known for the tree roots than they are for aerial parts. A few studies, summarized by Kramer and Kozlowski (1960, 
p. 52-53), suggest that diameter growth of roots starts later in the spring than does diameter growth of the trunk; however, growth continues for a longer period in the summer in roots. Some evidence also suggests that root growth is rapid in the spring and again in the autumn. Rings are visible in cross sections of roots, but many of these rings are incomplete and may not represent annual growth (Brown and others, 1949, v. 1, p. 252).

The wood, or xylem, of stems and roots is composed of different kinds of cells; and because the size, number, and distribution of the cells are different in the two organs, stem and root wood will be described separately. Only the wood of trees belonging to the class Angiospermae, flowering plants, as opposed to that of trees belonging to the class Gymnospermae, cone-bearing plants, is described here because coniferous trees occur only rarely on flood plains in the latitude of Washington, D.C.

Wood of trees of flowering plants, the broad-leaved trees, is sometimes called porous because it contains cells in the shape of small tubes, called vessels, that appear as pores when viewed in cross section. Two kinds of porous woods have been defined on the basis of the size and distribution of vessels. In ring-porous woods the vessels formed early in spring are larger than those formed later in the growing season, and the change between them is abrupt. Viewed in cross section, a series of concentric rings are seen which are the rings of large vessels (figs. 10, 21). Oak used for furniture and ash and hickory used for small tool handles are examples of ring-porous woods. Vessels in diffuse-porous woods are about the same diameter and more or less evenly distributed across the annual rings. Some examples of diffuse-porous woods used in furniture manufacturing are cherry, maple, and birch.

Other cells that constitute wood of broad-leaved trees are tracheids, fibers, and parenchyma (Brown and others, 1949, v. 1, p. 193; Esau, 1953, p. 250). The size and arrangement of these kinds of cells distinguish root wood from stem wood. In root wood, fewer fibers are present; diameters of the cells are larger; and a larger volume of parenchymatous tissue, consisting of rays and cells, surrounds the vessels (Esau, 1953, p. 512-513). Brown and others (1949, v. 1, p. 251-255) concurred with these differences. They also stated that the specific gravity of root wood averages about 20 percent lower than that of stem wood, and that root wood tends to be diffuse-porous in ring porous species.

Physiological processes within the apical meristems play a major role in controlling the form of trees from which evidence of floods is discovered. Vegetative buds and flower buds start to form early in the growing season on the current year's twig-about the time that twig elongation stops. The buds mature well before the end of the summer. New twigs and leaves grow from the vegetative buds during the following spring. Plant scientists have known for nearly half a century that a growth hormone is produced in the growing tips of plants and is translocated to other areas where it affects physiological processes within the plant. Much of the following discussion is based on Leopold's (1955) review of the existing knowledge of hormones and their use in agriculture. The function of growth hormones which concerns the work reported here is the inhibitive effect upon lateral bud growth and, as a corollary, the effect of light and gravity upon hormone distribution in a trunk (Leopold, 1955, p. 96-102).

As a result of the inhibitive effect of growth hormones in lateral bud growth, plants possess an apical dominance as long as the terminal buds remain alive. Removal of growing terminal buds results in growth of lateral buds. Subsequent application of hormones to the abscised tip will inhibit growth of lateral buds, thus restoring apical dominance. Both the force of the water and the debris carried by the water during floods decapitate trees and shrubs in their path, thereby destroying the growing tips of the plants and, with them, the source of the growth hormones. The result is the initiation of growth of lateral buds (fig. 2) and the development of one or more sprouts.

In addition to lateral buds that start to grow upon loss of apical dominance, adventitious buds are stimulated, and their growth gives rise to new stems. Growth of some adventitious buds is initiated by spontaneous cell division in several tissues within the stem (Esau, 1960, p. 229), whereas growth of others is believed to arise from preexisting dormant bud cells (Eames and MacDaniels, 1947, p. 63; Kramer and Kozlowski, 1960, p. 387). Growth of sprouts starts from adventitious buds on mature parts of trunks that have been severely damaged by floods and that remain as stumps or as decapitated water-felled trees.

Gravity and light have been demonstrated to affect the movement of growth hormones in stems and thus affect the growth behavior of plants. Hormones become concentrated in the lower side of inclined stems because of gravity and migrate toward the shaded side of unilaterally lighted stems; thus the inhibiting effect of hormones on growth of buds on the lighted side is lost. For these reasons, stems normally grow almost vertically upward. Migration of hormones toward the shaded side of stems also explains the phenomenon, familiar to many, of the growth of branches on a previously clear tree trunk after it has been exposed by 


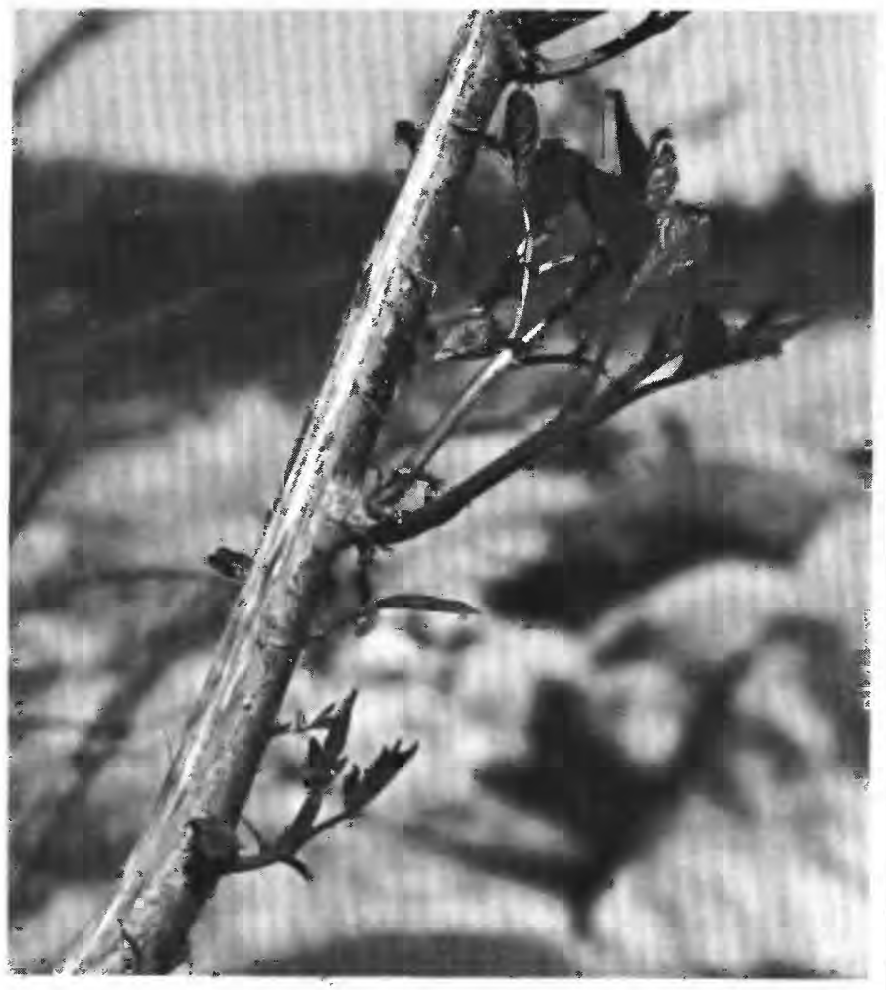

Figdre 2.- Sprouts that started to grow from ash stem after flood of May 1, 1958, damaged first growth of 1958 growing season. Photograph taken in vicinity of Chain Bridge, Washington, D.C., May 22, 1958.

the removal of surrounding trees. Even if some quantity of hormones is produced in water-felled trees, much of it will migrate to the lower, shaded side of an inclined tree; this results in a loss of the inhibiting effect upon adventitious buds on the upper surface.

\section{HYDROLOGIC CONCEPTS}

\section{COLLECT1ON OF STREAMFLOW RECORDS}

Although the methods used in the collection of streamflow records are well described in the literature (Corbett and others, 1945; Linsley and others, 1958; Johnstone and Cross, 1949), a brief summary of U.S. Geological Survey methods is presented here for those unfamiliar with hydrologic techniques. The U.S. Geological Survey is responsible for the collection and analysis of basic water facts and for research on hydrologic principles which will lead to a better understanding of water in its natural environment. Part of the basic data is collected at more than 7,000 gaging stations where continuous records of streamflow are obtained. In addition, partial records of lowflow or of floodflow are collected at many other points. At the gaging stations the elevation of the water surface, which is ordinarily called the stage, is recorded.

Periodically, generally about once a month, each gaging station is visited, the recording instrument is serviced, and a discharge or streamflow measurement is made. The discharge is computed from the mean velocity of the water, measured with a current meter at many points across the stream, and from the area of the cross section of the channel at the measuring section. Discharge measurements are made during low stages and flood stages as well as at times when the gage is regularly serviced; thus, data are accumulated that permit the development of a stage-discharge relation. The stage, as recorded on the gage, is plotted as the ordinate against the simultaneous measurement of discharge. The continuous record of stage, accordingly, can be transformed into a continuous record of discharge, or the amount of water flowing in the stream. The daily mean discharge, expressed in cubic feet per second for all gaging stations, is published annually in the U.S. Geological Survey Water-Supply Papers. A cubic foot per second (cfs) is defined as the discharge of water in a section 1 foot wide and 1 foot deep flowing at a velocity of 1 foot per second. More detailed information on streamflow, including peak flood discharges, is available at the U.S. Geological Survey district offices.

\section{COMPARISON OF FLOODS}

A record of the crest stage or of the instantaneous peak discharge of a flood is of limited value if the flood cannot be related to other floods. One method of comparing floods is based on their frequency of occurrence in time. The concept of frequency of events in time is familiar to all who have an interest in natural history, even if that interest is merely avocational. The vacation camper knows he should not camp overnight in an arroyo because of the danger of frequent floods. Picnickers often state, when a thunderstorm breaks just after the food is spread, that it always rains when they have a picnic, implying that such events are frequent. The analysis of floods that compares one with another is called flood-frequency analysis and tells the average interval between floods that exceed a given magnitude.

The frequency of floods and their relative magnitude, as one would expect, are inversely related. The smaller floods, which most people never recognize, are frequent; and such floods may recur once every year or two. The severe floods, the ones described by news media, are infrequent; and these may happen on the average only once in 50 or 100 years. If many classes of mean daily discharge, ranging from the minimum to the maximum, are chosen and the number of days on which each of these flows occurred is tabulated, then a plot of their frequency distribution would tend to be normal. Minimum and maximum flows would occur 
on the least number of days, and median and average flows would occur on a larger number of days.

Several methods of analyzing flood events have been used (Benson, 1962); the method of flood-frequency analysis based on peak discharge as used by the U.S. Geological Survey (Dalrymple, 1960, p. 5-21) will be outlined briefly. The annual flood, which is the highest peak discharge between October 1 of one year and September 30 of the following year (the water year), is listed, and the array is called the annual flood series. Another series, the partial-duration series, requires listing of all floods above a base dischargethat is, all independent peak discharges greater than a selected discharge. From either of these listings, the average recurrence interval can be calculated. A flood having a recurrence interval of 2 years, for example, has one chance out of two, or a 50 percent chance, of occurring in any one year. A flood having a recurrence interval of 50 years, the 50 -year flood, has a 2 percent chance of occurring in any one year.

Neither method was used in its entirety in this study, but floods having peak discharges above a base of $33,100 \mathrm{cfs}$ were listed. This discharge is the minimum flow for which evidence of damage to trees has been found along the Potomac River. Some difficulty was encountered in determining the independence of flood peaks in the lower range of discharges, and some of the floods listed might not have been independent of preceding floods. However, as suggested by Dalrymple $(1960$, p. 11-12), only those peaks were recorded that were separated by a trough that was 25 percent lower than the lower flood peak. The recurrence interval of only those floods above 82,100 cfs was calculated, using graphical methods outlined by Darling (1959). This base flow was chosen because it is the discharge of the flood that just cover the buried tree (discussed on p. 18-23) that was analyzed to develop a method of dating deposits on flood plains.

\section{FLOODSTAGE-DISCHARGE RELATIONSHIP}

At a gaging station the crests of floods, as well as the stages of all other flows, are recorded. Because in many studies, as in this one, the part of the flood plain involved is remote from the station, other techniques are used to record the elevation of flood crests. These employ visual reading of various types of gages, recording the crest on a crest-stage gage, and mapping of flood marks. In the present study, crests were determined by using crest-stage gages and by mapping flood marks.

A crest-stage gage (Ferguson, 1942) consists of a length of 2-inch pipe fastened to a tree near the bank of a river. The pipe, which has a vented cap at the top and a perforated cap at the bottom encloses a stick equal to the length of the pipe. A small amount of ground cork is placed in the bottom cap, so that when the river rises around the pipe, the holes in the bottom cap permit the water to rise in the pipe, thereby floating the cork. When the water recedes, the cork adheres to the stick at the highest level reached by the water, and the elevation of the ring of cork is readily determined.

Flood marks can be found on the flood plain after recession of the water, and these are variously mapped. In this study, bench marks were installed at many points along the river-study reach in connection with installation of the crest-stage gages and other instruments, so elevations of flood marks at any point in the reach can be determined readily by leveling. Also, flood marks on banks delimiting inundated areas of flood plain were mapped on aerial photographs.

The peak discharge of the various floods in question can be obtained from the gaging-station record and a correlation defined between stage at the various sites under study and the rate of flow at the reference gaging station. (In this study the station record is that of Potomac River near Washington, D.C., located near the Washington, D.C.-Maryland boundary [Fig. 1].) The complete gaging-station record is then $\mathbf{e x}$ amined, and the dates and quantities of all discharges that have equaled or exceeded the floods of interest are listed. The peak discharge of the flood, rather than stage, is used in listing flood events and in subsequent analyses. Separate floods on a given river having the same peak discharge do not attain exactly the same relative elevation throughout the reach of the river owing to variations in distribution of tributary flow or changes in physical character of channel and flood-plain sections. Conversely, separate floods that attain the same elevation at a given section do not always have the same discharge.

\section{EFFECTS OF FLOODS UPON TREES}

The high velocity of water and the large quantity of transported debris are the two characteristics of floodflow most damaging to flood-plain trees. With an increase in discharge, or streamflow, during a flood, the velocity of the water usually increases. Discharge measurements at the reference gaging station are made most of the time from Chain Bridge, which spans the Potomac River in Washington, D.C., where velocities are so high during floods that current meters, if used, would be damaged or destroyed (L. W. Lenfest, oral commun., 1956); in fact, velocities higher than 20 feet per second have been recorded at Chain Bridge during minor floods (Leopold, 1953, p. 608). Discharge measurements of the peak flow during floods that occur 
VEGETATION AND HYDROLOGIC PHENOMENA

about once every 2 years and during larger ones that occur less frequently are made from a highway bridge over the tidal estuary about 7 miles downstream where velocities are lower. The velocities of water along the banks, over low brush-covered islands, and at the upstream ends of larger islands, therefore, are exceedingly high, and the force of the water is sufficient to injure trees in the flood path. The water alone will bend small trees, break off tops, and remove leaves if the flood occurs in the summer.

Anyone who has walked along a river after a flood is keenly aware that all manner of debris is carried by flood water. This debris consists of logs, branches, leaves, and other fragments from flood-plain vegetation, and of all kinds of human accouterment. Floating ice during late winter and spring floods are particularly damaging to trees and other flood-plain vegetation.

\section{PHYSICAI EFFECTS OF HIGH VELOCITY AND DEBRIS}

The physical damage caused by floods and floating ice has been described by many observers. Lindsey and others (1961, p. 125) stated that ice floes during the February 1959 flood along the Wabash River in Indiana abraded the bark and broke branches from trees along the river bank. They noted a line of scarring in vegetation for a considerable distance along the bank, and they believed it represented the crest of the flood. I observed a similar crest line of scarring in plants along the banks of the Potomac River after floods and along banks of the Ohio River near St. Marys, W. Va., in June 1959. I attribute this line on the Ohio River to damage to trees by floating ice in February 1959. Damage to trees by floating ice has been reported in other areas (Cribbs, 1917, p. 148), and on rare occasions in the Southeastern United States (Putnam and others, 1960, p. 20).

The results of uprooting, breaking, shearing, and scarring of trees by high water during floods are commonly seen in flood-plain forests and have been reported by several workers. Lindsey and others (1961, p. 124) observed these types of damage to trees along the Wabash River following the February 1959 flood. They also noted that small willow trees (Salix interior) showed deformation similar to that of windtrained trees and suggested calling this a "floodtrained" form. Shrubs in the arroyos in the Rio Grande valley in New Mexico are knocked over and partly buried by high water (Gardner, 1951, p. 398). Shull (1944, p. 774-775) observed that willows along the banks of the Mississippi River suffer damage during high water and that although the tops of many trees may be killed, the roots of most will survive. Dore and Gillett (1955, p. 15) stated that ice on the St. Lawrence River kills tree seedlings and perennial plants along the shore in the International Rapids section. Ware and Penfound $(1949$, p. 478) observed that most plants on sand bars in the channel of the South Canadian River in central Oklahoma are killed by annual floods.

Severe floods of extremely rare occurrence at any one place will destroy all trees on parts of the flood plain (Hack and Goodlett, 1960, p. 49). This type of destruction of flood-plain vegetation along small streams in the Appalachian Mountains may occur more commonly than is generally believed; in fact, Hack and Goodlett (1960, p. 55) suggested that such damage may be more frequent in the southern Appalachians than in the northern Appalachians. Landslides that occurred in the southern Appalachian Mountains in August 1940 destroyed large swaths of forests on hillsides and in stream valleys below (Water Resources Branch, 1949, p. 14). Similar slides occurred in central Pennsylvania on July 18, 1942, and destroyed stands of trees on slopes and in stream valleys (Eisenlohr, 1952, p. 78). Such catastrophic hydrologic events occur in Western United States as well. A most striking debris flow occurred during the night and early morning of October 2-3, 1947, on Kautz Creek in Mt. Rainier National Park when an estimated 50 million cubic yards of rock, gravel, sand, and logs moved down the valley (Grater, 1947, 1948), destroying and inundating an extensive area in a mature coniferous forest. Accounts of damage to vegetation are included in most flood reports published by State agencies, the U.S. Geological Survey, and other Federal agencies.

The larger study, concerned with the relationship of vegetation to the hydrology of streams, of which the one reported here is a part, is being made in areas along the Potomac River where stands of trees have survived several major floods. The magnitude and dates of occurrence of these floods are discussed on $p$. 29. Individual trees have been found that were growing prior to floods in 1861, 1889, and 1924 . Several stands that contain trees that were growing prior to the 1936, 1937, and 1942 floods have been studied. Most of the forest along one reach of the river in the vicinity of Chain Bridge near the northwestern boundary of Washington, D.C., consists of trees growing from stumps of trees that were cut off or felled by a severe ice jam on February 16, 1948 (fig. 5). The relationship between flood frequency and sedimentation and the form, distribution, and age of the trees in this part of the river is under investigation and study. 
All flood-plain trees that were growing prior to floods of record have, of course, experienced subsequent floods. The majority of flood-plain trees, as a result of this experience, show varying degrees of damage; so that most are small and have poor form or are, in forestry terms, of low quality (fig. 3). The trees are bent and twisted and consist of several sprouts growing from different sizes and forms of stumps. Trunks of trees along the banks of a channel and on upstream ends of islands commonly exhibit scars that have resulted from repeated abrasion by debris and ice carried by high water (fig. 4). The only concentrations of large and straight, single-stemmed trees grow on the higher ridges of the flood plain and at considerable distances from the river channel.

Severe floods such as the ones that crested on March 19,1936 , and October 17, 1942, and the ice jam that occurred on February 16, 1948, (figs. 5, 6) inflict great damage to a large number of trees. Most of the trees in the paths of these floods or of the ice jam were bent over or partly uprooted, and the crowns were heavily pruned. As long as 25 years after such an event, the trunks of trees are still bent and inclined in a downstream direction and have scars on the upstream side.

High wind also fells flood-plain trees, but windthrown trees on flood plains, as well as on uplands, are oriented at random and not in a general downstream

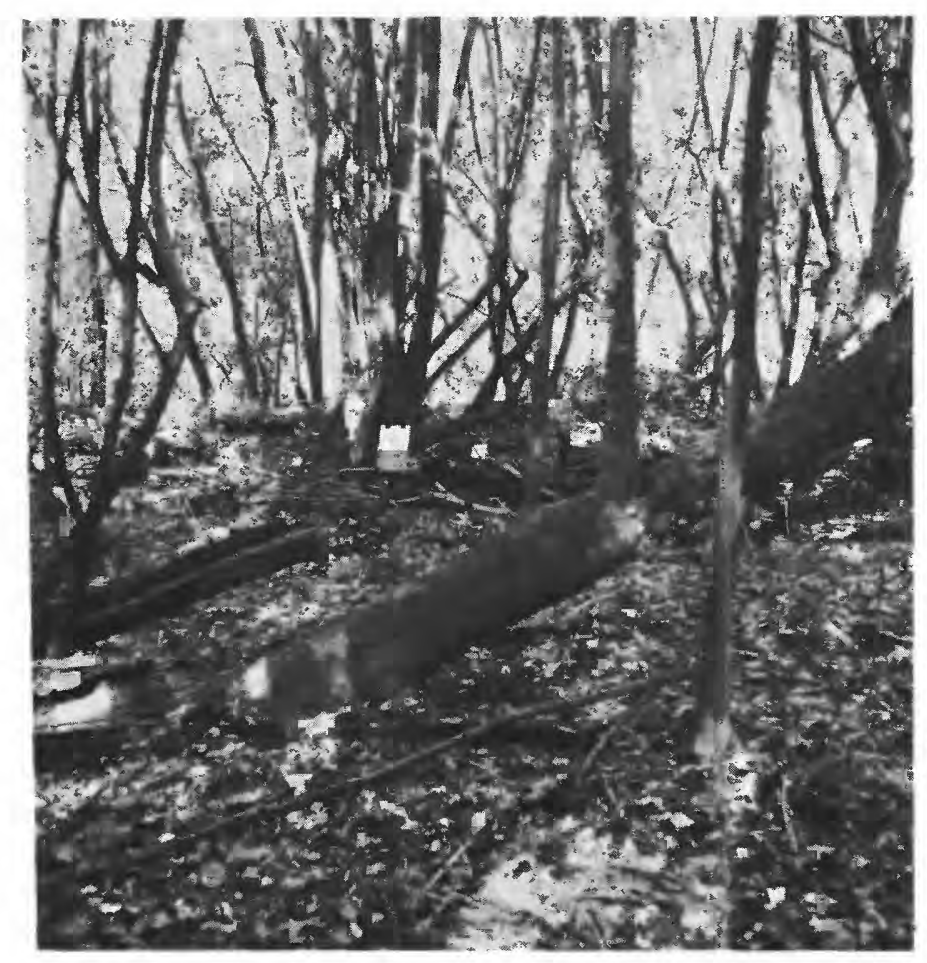

Figure 3.-View of flood-plain forest showing poor form and sprout origin of trees.

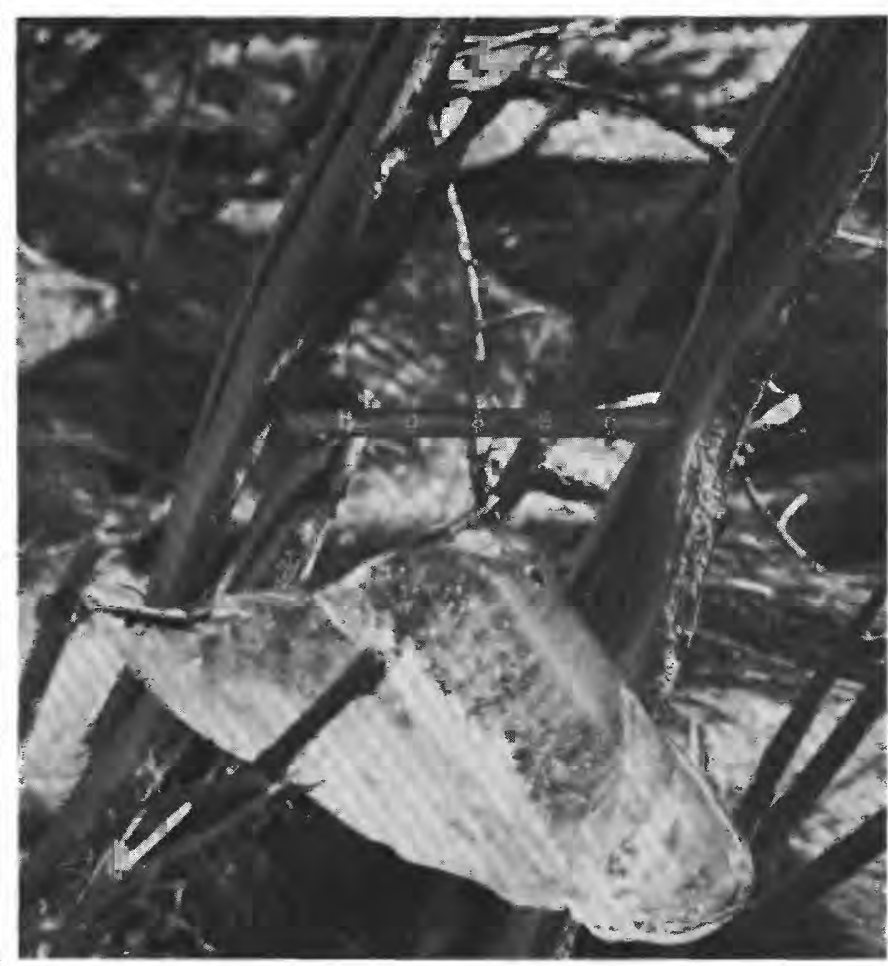

FrgURE 4.-Floating ice overriding flood plain scars trees. Ice fragment lodged in small ash tree that shows light-colored wood exposed by ice abrasion on January 15, 1958.

direction; furthermore, many wind-thrown trees are broken into a decapitated trunk and the top, which eventually dies. In contrast, most trees felled by high water are partly uprooted. Adventitious roots start to grow from the part of trunk in contact with the soil, and the fallen tree continues to live.

The percentage of stems showing evidence of flood damage was determined in December 1962 in seven plots located at random along the Potomac River. The plots were approximately 50 by 50 feet square. Six of them are in areas underlain by bedrock or fine-grained alluvium and are flooded at different frequencies. The surface of the seventh plot, plot 2, consists of alternate ridges of alluvium and flood channels in which bedrock is exposed in the bottom. Plots 1-4 are upstream from Washington, D.C., near the Maryland State line; plots 5-7 are on an island approximately 16 miles upstream from plot 4 , near Seneca Falls (fig. 1). All woody stems in two plots, numbers 3 and 4 , grow as sprouts from stumps or root crowns with the exception of silver maple ${ }^{1}$ seedlings less than 1 year old. In these two plots, bedrock crops out and the surface is flooded on the average about 5 percent of the time. In the other plots, the percentage of stems showing damage ranges from 52 to 85 ; the

1 Nomenclature of trees follows that used by Little (1953). 

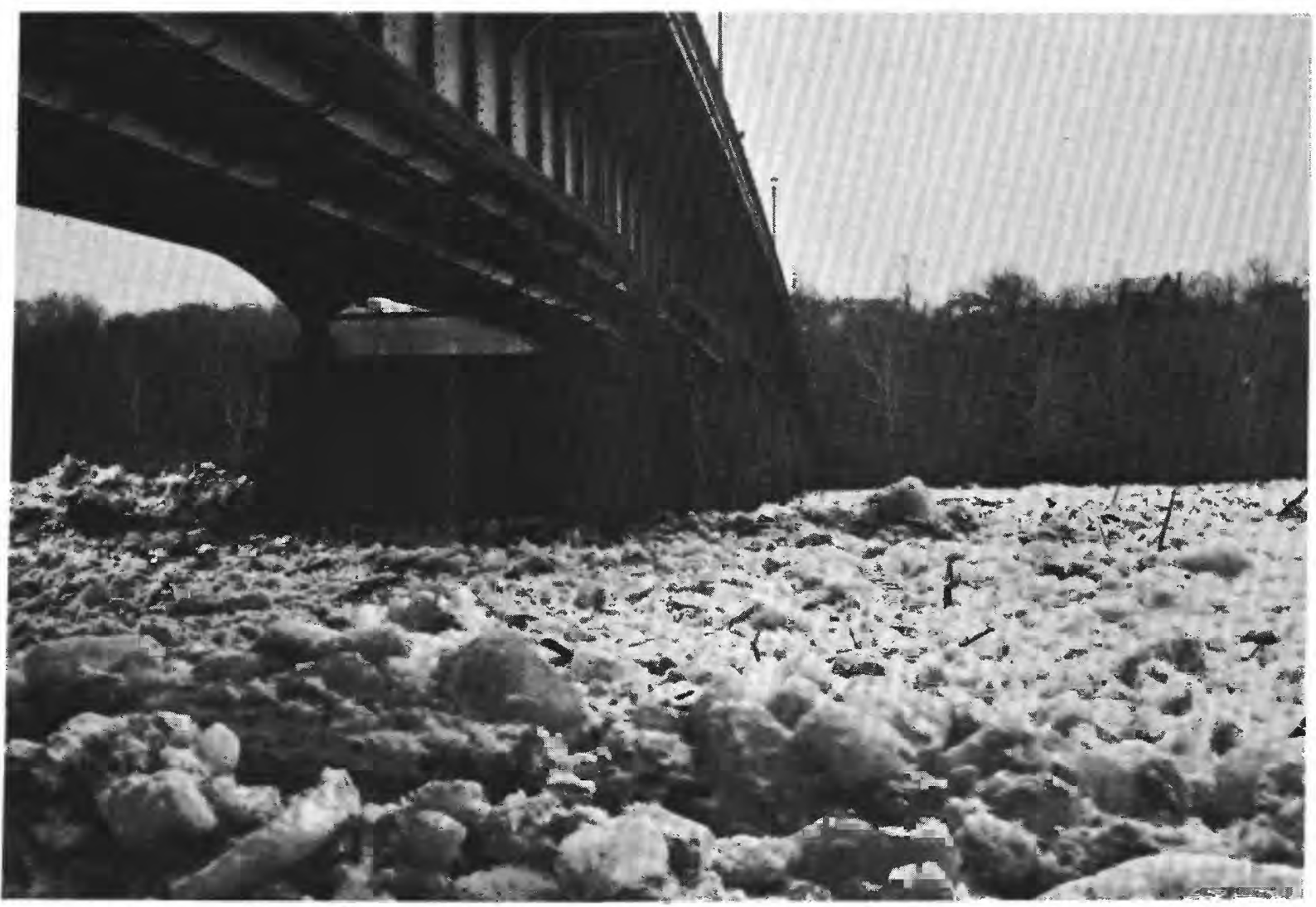

Figure 5.-Ice jam on Potomac River at Chain Bridge, Washington, D.C., February 16, 1948. The Washington Post photograph.

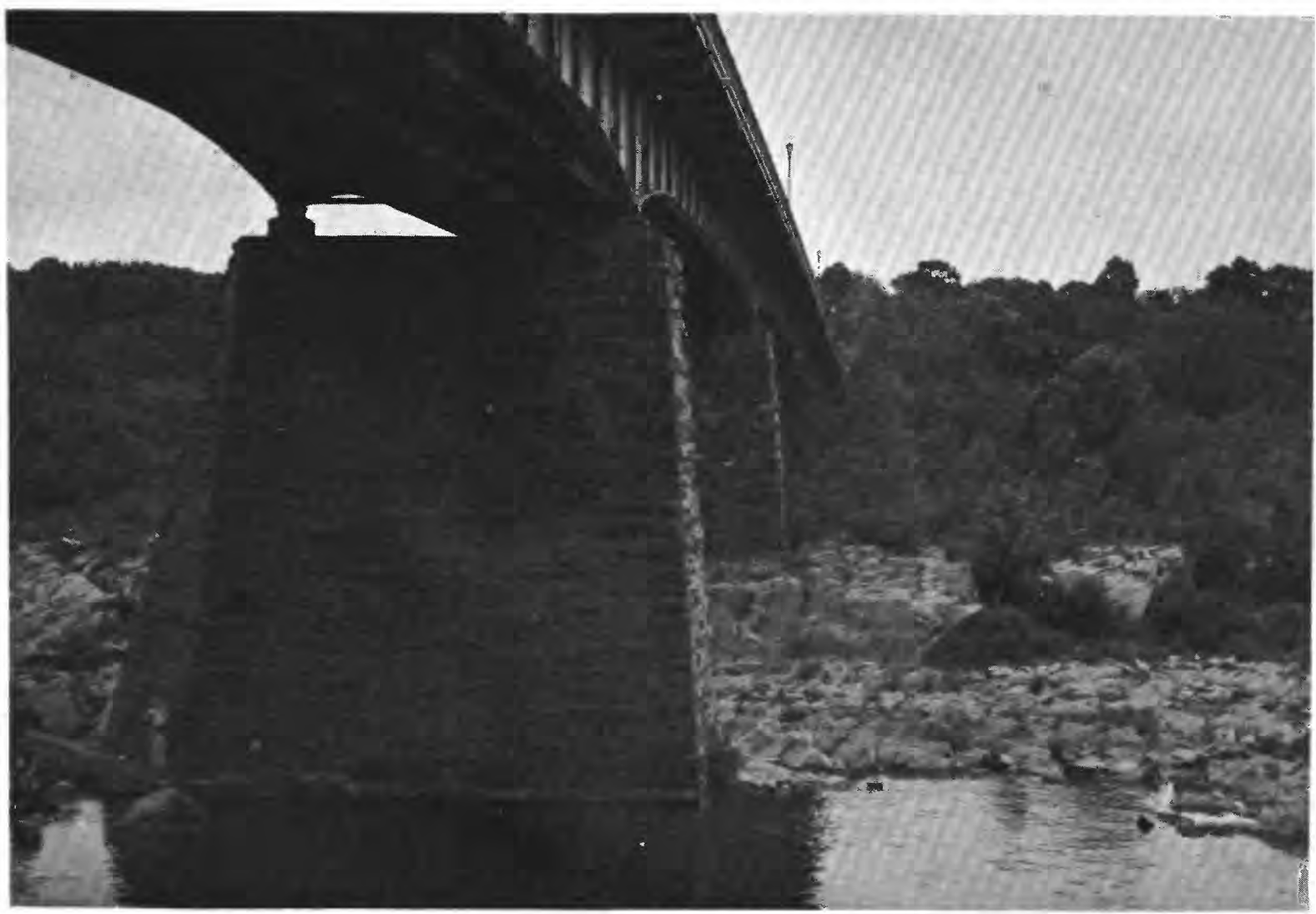

Figure 6.-Low flow on Potomac River at Chain Bridge, Washington, D.C., July 1956. 
data are summarized as follows:

\begin{tabular}{|c|c|c|c|c|c|c|}
\hline Plot & Area & Surface ${ }^{1}$ & $\begin{array}{c}\text { Number } \\
\text { of } \\
\text { floods } 2\end{array}$ & $\begin{array}{l}\text { Total } \\
\text { stems }\end{array}$ & $\begin{array}{l}\text { Number } \\
\text { of stems } \\
\text { damaged }\end{array}$ & $\begin{array}{l}\text { Percent } \\
\text { of stems } \\
\text { showing } \\
\text { damage }\end{array}$ \\
\hline & \begin{tabular}{|l} 
Chain Bridge \\
do \\
Spaldo \\
dong's \\
do
\end{tabular} & \begin{tabular}{|l|} 
Alluv \\
All. Br..... \\
Br....... \\
Br- \\
Alluv..... \\
Alluv.... \\
Alluv....
\end{tabular} & $\begin{array}{r}17 \\
>17 \\
155 \\
155 \\
315 \\
>15 \\
315\end{array}$ & $\begin{array}{r}53 \\
52 \\
227 \\
260 \\
33 \\
16 \\
29\end{array}$ & $\begin{array}{r}41 \\
44 \\
227 \\
260 \\
28 \\
14 \\
15\end{array}$ & $\begin{array}{c}77.4 \\
84.7 \\
100 \\
100 \\
84.8 \\
87.5 \\
51.7\end{array}$ \\
\hline
\end{tabular}

${ }^{1}$ Alluv., fine-grained alluvium; All. Br., ridges of fine-grained alluvium and channels having rock bottoms; $\mathrm{Br}$., bedrock

2 Period of record, 3/1/30-4/1/62, 32 years, 1 month.

${ }^{3}$ Approximate.

General observation at many places throughout the area of study leaves the impression that the proportion of damaged trees is of the magnitude measured in the plots.

\section{EFFECTS OF INUNDATION UPON TREES}

The presence of living trees that have been flooded at least 20 times in more than 32 years and still survived is sufficient proof that high water alone does not kill them. In fact, detailed quantitative study along one part of the Potomac River shows no significant difference between vegetation that was covered by high water from February to May 1961 and similar vegetation studied during the preceding year, prior to high water. The quantitative studies have been briefly summarized, and the results of the measurements made prior to the high water are discussed (Sigafoos, 1961, p. C 248-250). This phase of the larger study is the subject of a second report that is in preparation.

Other workers have reported that high water alone during floods does not kill flood-plain trees but that extended periods of flooding and heavy sedimentation will kill them. Willow thickets along streams in Wyoming are believed to withstand repeated flooding for many years (Reed, 1952, p. 708). Taller trees, whose crowns extend above the crests of floods, were found to survive along the Mississippi River (Shull, 1944, p. 773); however, Shull (1922, p. 205-206) believed that young trees would be killed if submerged for a long time.

Several workers have noted that submergence during the dormant season will not kill flood-plain tree species (Putnam and others, 1960, p. 11, 13, 20, fig. 15; Harper, 1938; Turner, 1936, p. 693; Wistendahl, 1958, p. 150 ; Silker, T. H., 1948, p. 432-433, p. 436), and Lindsey and others $(1961$, p. 122-123) found that high water during two floods on the Wabash River in Indiana in June 1958 killed only the inundated leaves. Cribbs (1917, p. 148) stated that the period of submergence by floods on streams in western Pennsylvania is usually too brief and the amount of sediment deposited is generally too small to injure trees. Putnam and others $(1960$, p. 13,17$)$ stated that flooding even in spring will not kill most bottom-land tree species and that many will remain dormant until the water recedes; however, total submergence for long periods after breaking of dormancy will kill seedlings and small saplings. High water on the Illinois River from September to December 1926, in January 1927, and from April to mid-June 1927 is believed to have killed an estimated 90 percent of the mature timber on the flood plain (Turner, 1930). Turner believed that the high water from April to mid-June was most effective in killing the trees. In a study of the effects of flooding by the Kentucky Reservoir on the Tennessee River, Hall and Smith (1955) found that all woody species were killed if flooded about 60 percent of the time during the growing season. Bottomland species survived, they found, if flooded less than 42 percent of the time.

Submergence even for short periods during the growing season, however, will kill some trees and, for extended periods of several years, will kill all species. Flooding as a result of a beaver dam built across Carp Creek in Michigan killed all upland species in 1 year; however, black ash and American elm, species characteristic of flood plains, were not killed during this interval (Gates and Woollett, 1926).

Inundation for a period of 5 to 6 years by backwater of a dam on the Mississippi River killed all flood-plain tree species; and a study made during this period showed that young, rapidly growing trees evinced the greatest resistance to death, whereas old trees and young saplings were the first to die (Yeager, 1949, p. $37)$.

\section{GROWTH OF TREES AFTER FLOOD DAMAGE}

Trees continue to grow after they are damaged during floods; and subsequent growth, in a sense, preserves the injury. The identification and interpretation of this growth and of the flood-inflicted damage are the subjects of this section. It will be shown that parts of the bark and underlying tissues are killed and that scar tissue grows over the damaged area. Initiation of growth of the scar tissue can be dated. It will be shown also that sprouts grow from the residual stumps of flood-felled and decapitated trees and that the start of growth of these sprouts can be dated. The dates obtained from all specimens are those of the first growing season following the flood event.

\section{CIRCUMF ERENTIAL GROWTH AROUND TRUNK SCARS}

A sharp blow to a tree trunk, whether made by a lawn mower, by a baseball bat in the hands of a small boy, or by debris carried by high water, will crush, and thus kill, the living tissues between the bark and the wood. One of these living tissues beneath the bark is 
the vascular cambium, composed of thin-walled meristematic cells that divide, causing the tree to increase in diameter and circumference by the growth of annual rings. If the external force is sufficiently strong, or if prolonged, as during a flood, the bark is abraded and the wood becomes exposed.

Upon death of the cambium, a homogeneous tissue, called callus, forms around the margin of the scar and across it if the scar is small. New wood is not formed over the damaged area upon resumption of growth. Vascular cambium later differentiates within the callus and ultimately bridges the scar. As the cambium is forming, new wood also starts to form around the margin of the scar; and, in time, a new layer of wood will cross the scar, and a complete annual ring will encircle the trunk (Esau, 1953, p. 392, pl. 56, 57). This process of wound healing is illustrated diagrammatically in figure 7.

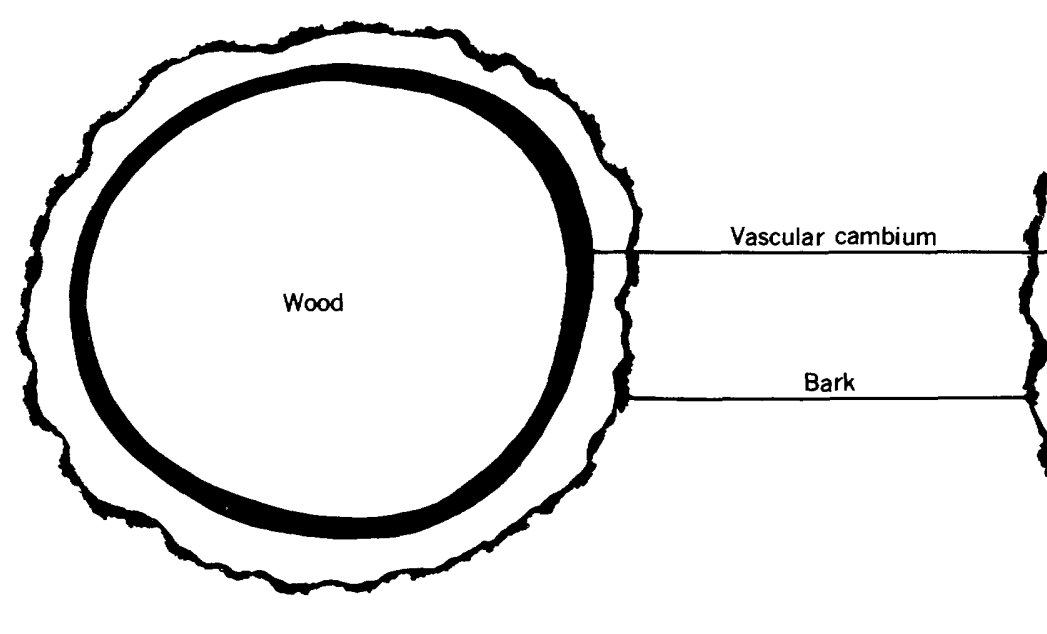

$A$ Before damage

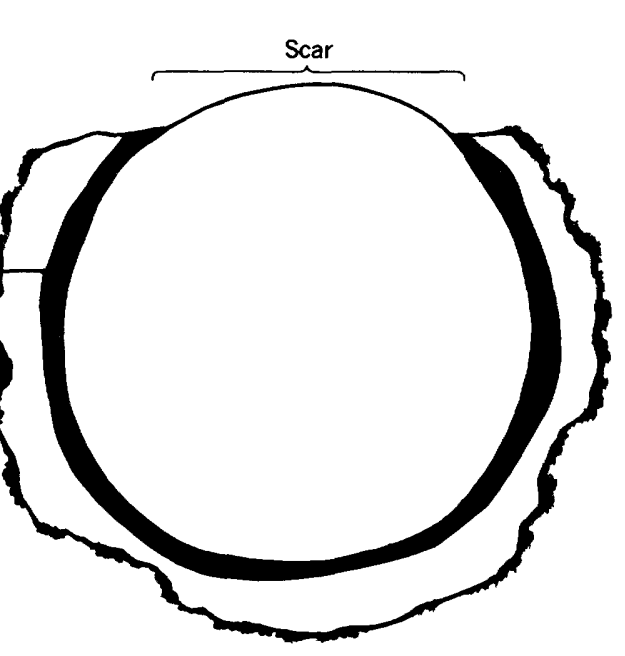

$B$ After damage
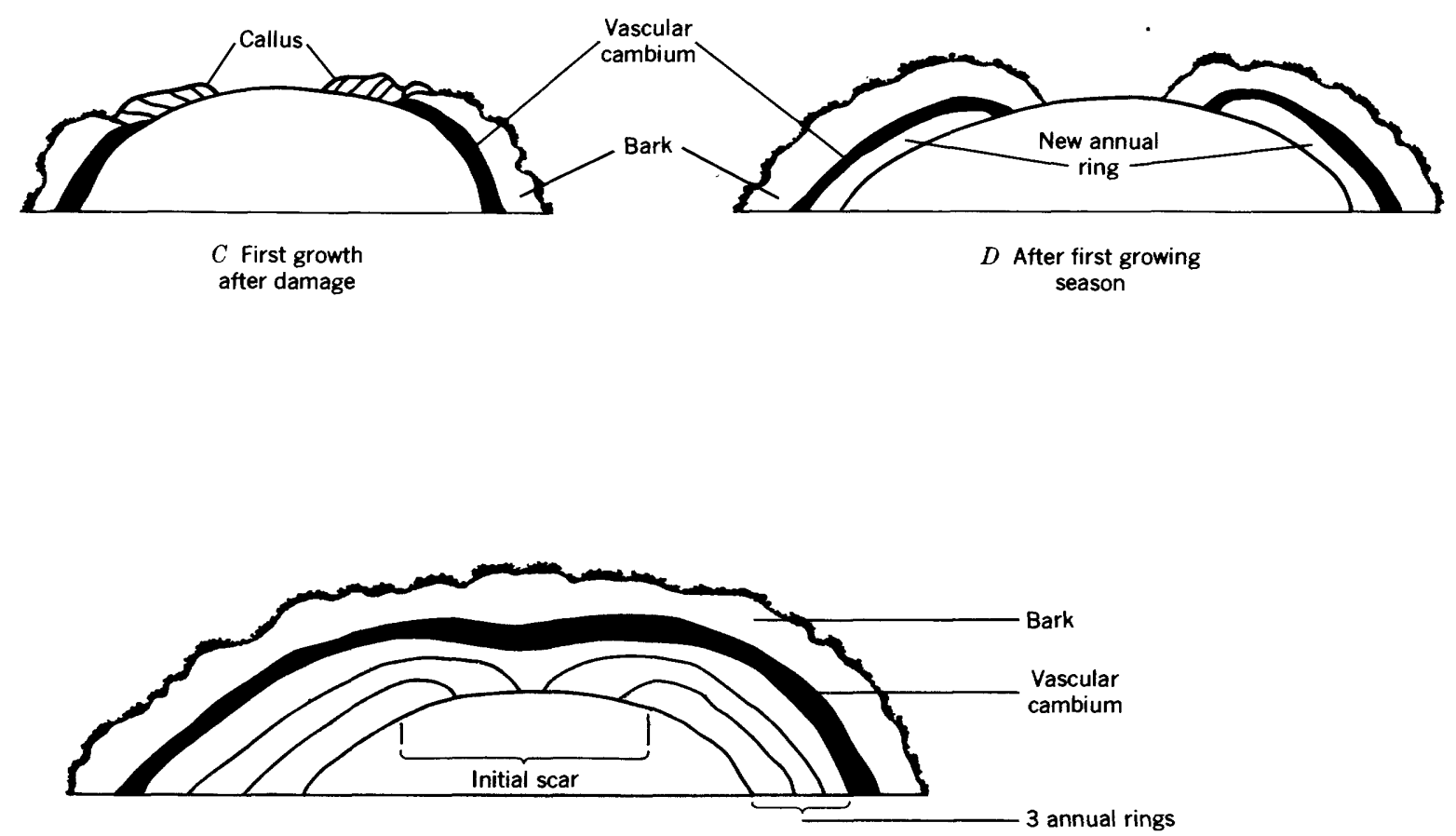

$E$ After three growing seasons

following flood damage

FIGURE 7.-Diagrams representing circumferential growth of trunk after destruction of bark and cambium. Width of the cambium is greatly exaggerated. 
The extent of healing and the length of time required for the scar to be completely covered with new wood are affected by the size of the initial scar, by the frequency of the event that causes the damage, and apparently by the time of year that the damage is inflicted. Scars that are a few inches long on twigs and stems smaller than about 1 inch in diameter will heal by the end of the growing season following the damage. Thus, small scars made during the spring or early summer generally are covered by new wood and bark by the end of the same summer. Larger scars, which encircle half the circumference of stems as small as half an inch in diameter and extend along most of the length, generally do not heal for several years. Large scars formed by ice abrasion of silver maple trees along the Tippecanoe River in Indiana in 1956 were seen in 1959 to be healing (Lindsey and others, 1961, p. 126). Because floods that damage trees on the lower surfaces of flood plains occur more often, on the average, than once a year, the repeated injury prevents many scars from ever healing.

A scar can be dated by taking a section through the trunk, tracing the last ring formed prior to injury along its circumference to the sound part of the stem, and counting the number of rings that lie outside. This number is equal to the number of growing seasons that have elapsed since injury. To count the annual rings in wood directly outside the scar is rarely possible, because the wood consists of callus, which does not contain annual rings, and generally shows an incomplete number of rings. Note in figure $7 E$ that three rings are represented outside the last ring formed before injury, yet only one complete ring overlies the center of the scar. If a large area of the stem is damaged and if damage, furthermore, is severe, part of the wood formed prior to damage may be eroded, so that the outer ring in the scarred area is not the last ring formed. The wood exposed by abrasion of the bark also may rot and subsequently erode before the scar is healed.

A description of the scars shown in one dissected small tree (fig. 8) and the record of floods will illustrate the relationship between flood damage and subsequent circumferential growth of stems, The tree was collected along the Potomac River near Washington, D.C., in a low area adjoining the channel which had experienced 147 floods in the period of streamflow record of 26 years and 10 months prior to the time of collection.

From the spring of 1952, when the oldest part of the stem shown in figure 8 started to grow, to January 20 , 1958, when the specimen was collected, the stem was subjected to 28 floods. Since 1954, when the youngest

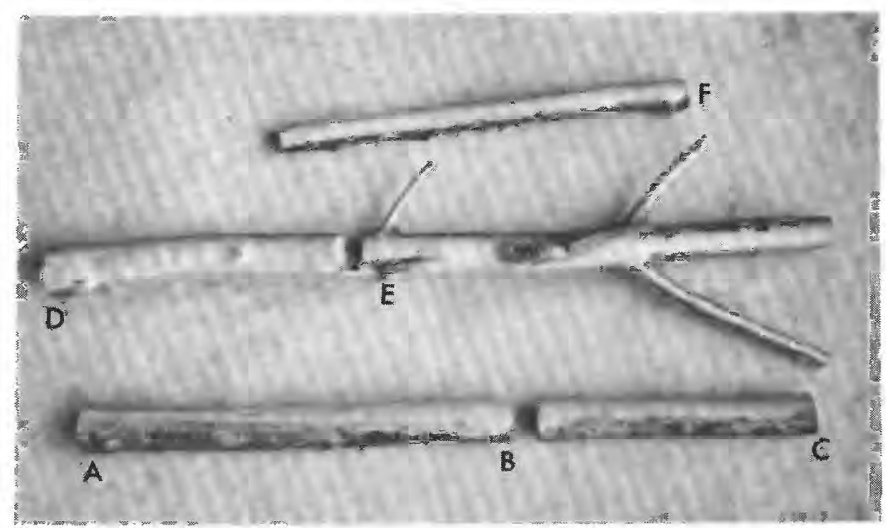

Figure 8-Parts of a stem of an ash tree growing in an area along the Potomac River where a minor ice jam occurred on January 15, 1958. The letters A-F correspond to sections shown in figure 10. The stem is $11 / 2$ inches in diameter at $A$.

part of the main stem included in figure 8 started to grow, the stem was subjected to 12 floods. Four of these floods are recorded in cross sections of the stem, and a fifth is evident in the stem itself. The stem is a sprout that grew from a stump that is inclined in a downstream direction. Six floods that could have felled the parent tree occurred after the growing season of 1951 and before the growing season of 1952 . The use of ages of sprouts as evidence of floods is discussed on pages 12-18. The bark (fig. 8) was abraded by floating ice that covered the area on January 15 ,

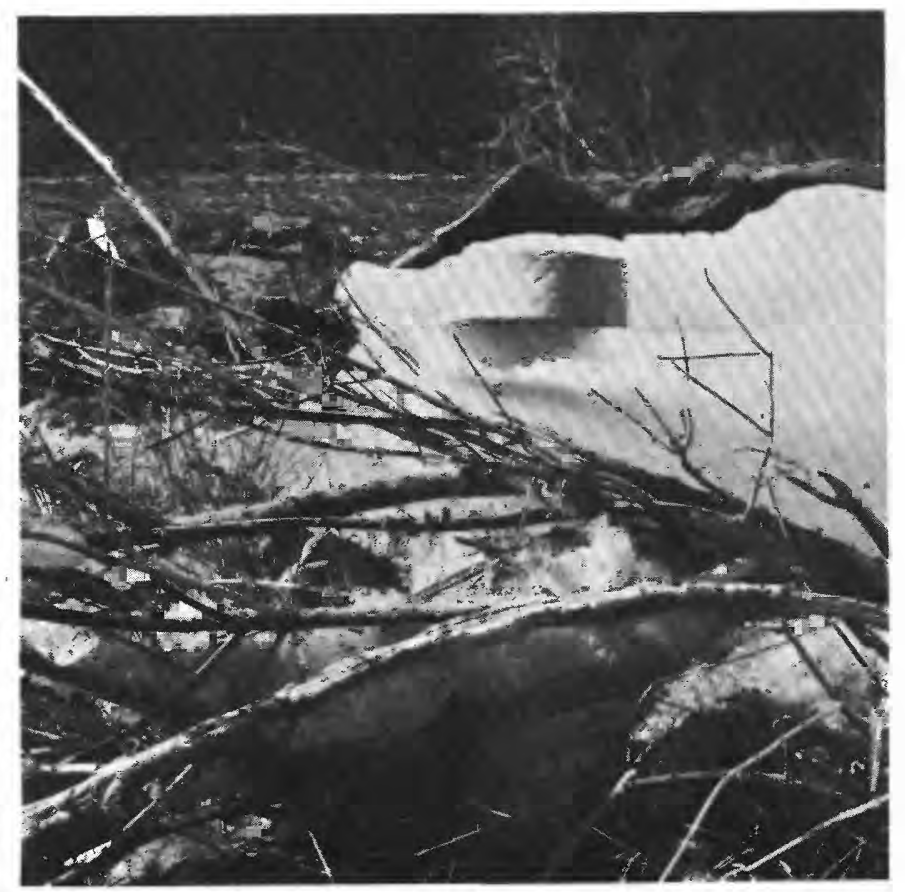

Figure 9.-Fragments of ice deposited on flood plain of Potomac River on January 15, 1958, in area where tree in figure 8 was collected. The lightly shaded parts of the stems are bare wood and are on the upstream side of the stems. 
1958 (fig. 9). Subsequent observations in this area suggest that some stems of trees similarly damaged in 1958 have died, whereas many others have survived. Indeed, sections of a number of trees collected in late August 1960 show two rings outside a scar that is attributed to the 1958 ice jam.

Cross sections through parts of the stem (fig. 10A-F) show healed scars on the upstream sides of the sections which are at the top in figure 10. Three annual rings have grown outside the scar in sections $A, B$, and $F$; thus the scar was formed before the growing season of 1955. The scar is on the outer part of the ring that grew in 1954; therefore, damage occurred between the fall of 1954 and the spring of 1955 during any one or all of four floods that covered this area during that time. Another scar is present between the 1955 and 1956 rings in section $E$; the fourth highest flood of record on the Potomac River occurred on August 20, 1955 (fig. 11, 12). The scar present within the 1956 ring in sections $C$ and $D$ may have resulted from a sharp rise in the discharge of the Potomac River at Chain Bridge to a peak of 72,500 cfs on July 21,1956 , following an intense local storm which occurred in the lower part of the Potomac River basin on July 20-21, 1956 (Water Resources Division, 1964). Summarized below are the types of botanical evidence of flood-induced damage seen in the sections in figure 10 , the years when they were created, the dates of the possible floods involved, and the peak discharge.

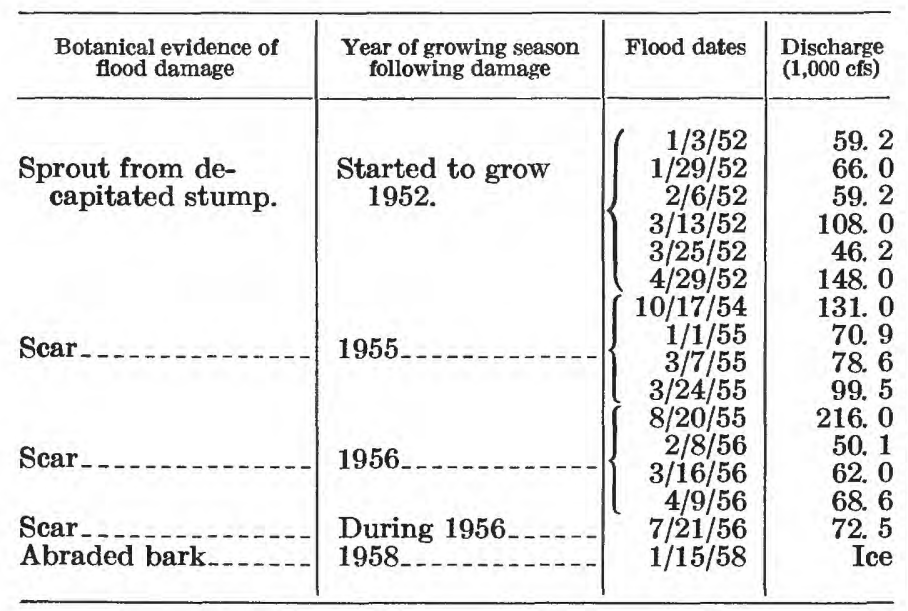

The types of scars described in the preceding discussion are inferred to have been caused by floods: they are on the upstream side of the stem and are dated. Moreover, floods were recorded during the interval when the scars were formed. Many trees from this area have been sectioned, and all show evidence of damage that can be related to a flood. Abrasion of bark by floating ice and debris which had occurred during the period of this study was observed during the particular flood, and the effects were subsequently seen within a few days after the water had receded. These observations exclude, of course, trees cut by boys, by fishermen, or in lumbering operations. Although many floods occurred for which evidence was not found in the sections of the specific tree discussed here, scars resulting from some of these floods may be embedded in parts of the stem that were not sectioned. Scars formed during the time of some of these other floods, however, have been found in other trees growing in the same area.

\section{GROWTH OF SPROUTS FROM STUMPS AND WATER-FELLED TREES}

The physical effects upon trees of floods of high magnitude that occur less often than once every 2 years, on the average, and evidence of flood damage have been inferred only from the form of trees growing on surfaces known to have experienced these severe floods (fig. 11, 12). Floods of high magnitude have not occurred since this study began.

Trees larger in trunk diameter and height than those described in the preceding section show evidence of severe flood damage of a different kind. These trees consist of sprouts growing from a stump or inclined trunk, show a sharp angle near the base, or look, at the base, like a pole implanted in the ground. They have a form that is more treelike, consisting of one or more straight trunks that are unbranched for a third or more of their length. They are not multistemmed, much-branched shrubby plants. Wistendahl (1958, p. 140-141, 150) found that willow, river birch, sycamore, and box elder trees produce sprouts following damage by floods on the Raritan River in New Jersey. Shull (1944, p. 774-775) noted that sprouts grew from root stocks of willow trees whose tops had been killed during floods along the Mississippi River.

Heavy flood debris materially damages flood-plain trees and locally breaks the trunks near the ground, leaving a ragged stump. Severe ice jams have cut off most trees in large areas of the Potomac River flood plain. Sprouts start to grow from these stumps during the first growing season following the damage and, if not subsequently damaged by another flood, continue to grow as straight-stemmed trees (fig. 13). The sprouts pictured in figure 13 started to grow in 1948; the parent tree was probably cut off by an ice jam on February 16, 1948, that was about 15 feet deep over the area (fig. 5). Apparently all heavy ice flows do not cut off most trees. Lindsey and others (1961, p. 125-126) reported that floating ice also twisted and bent flood-plain trees during the flood of February 1959 on the Wabash River in Indiana. They observed 


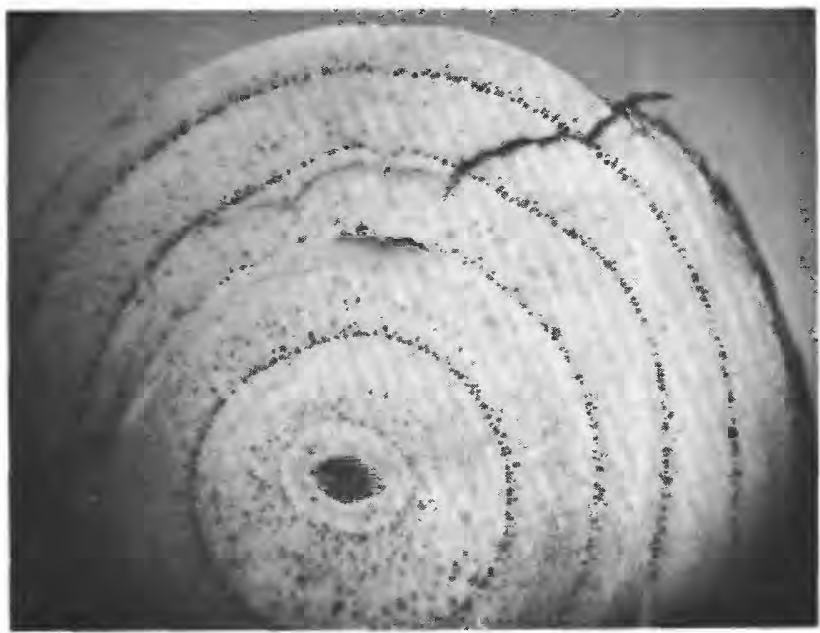

$A$

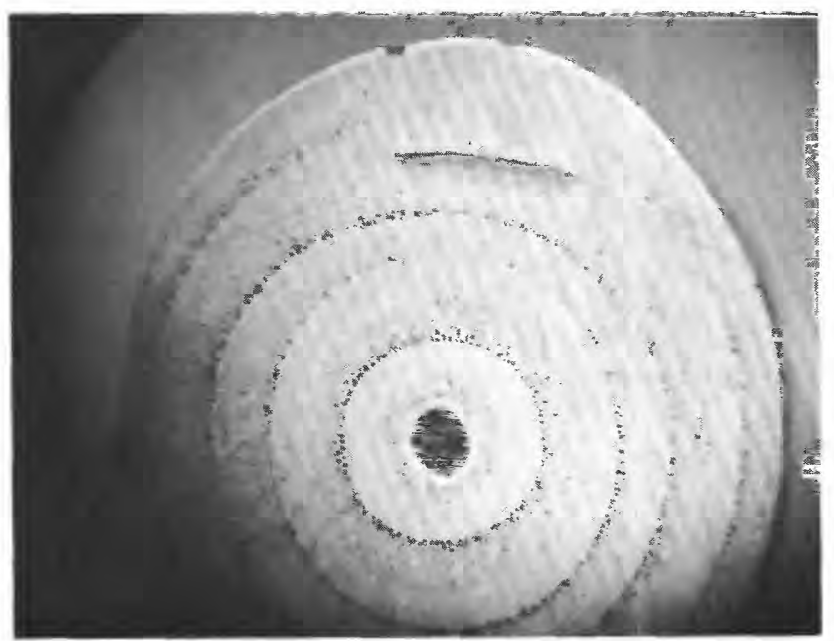

C

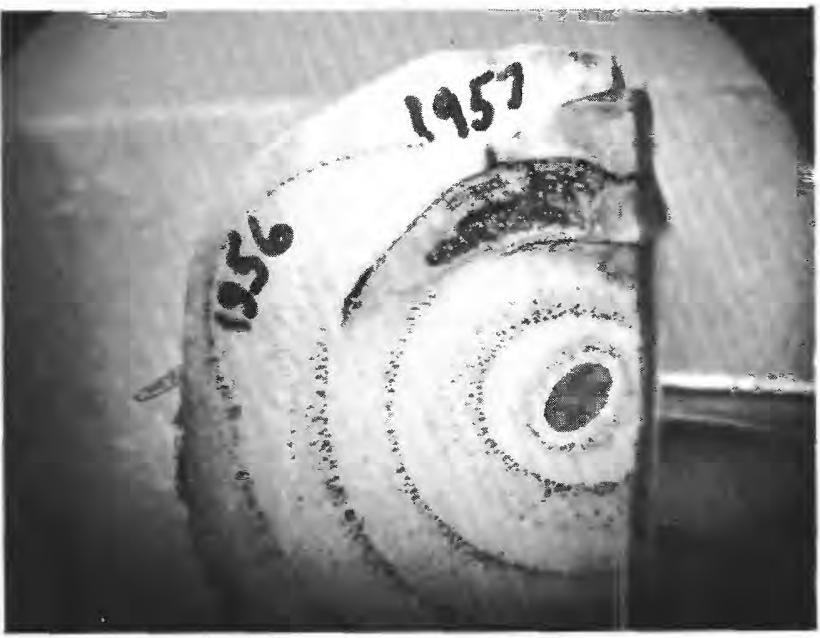

$E$

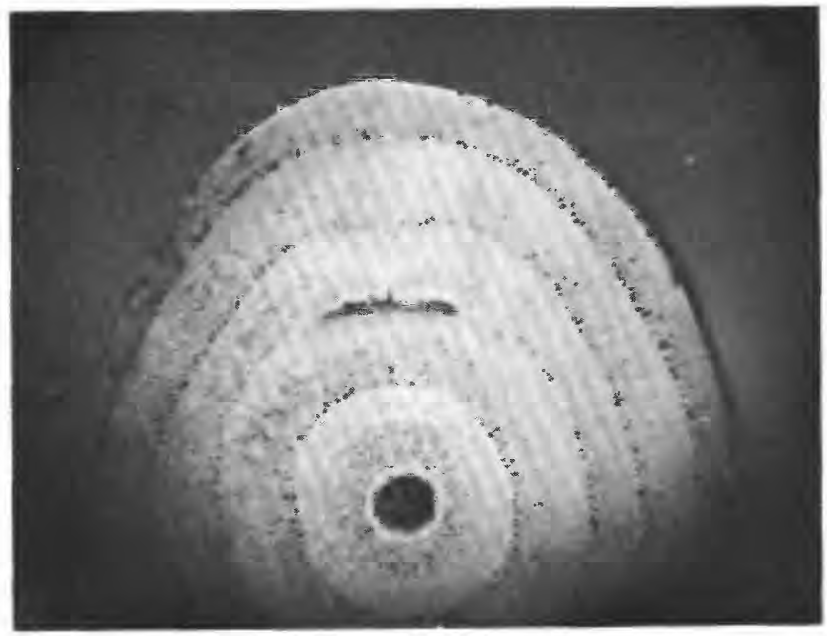

$B$

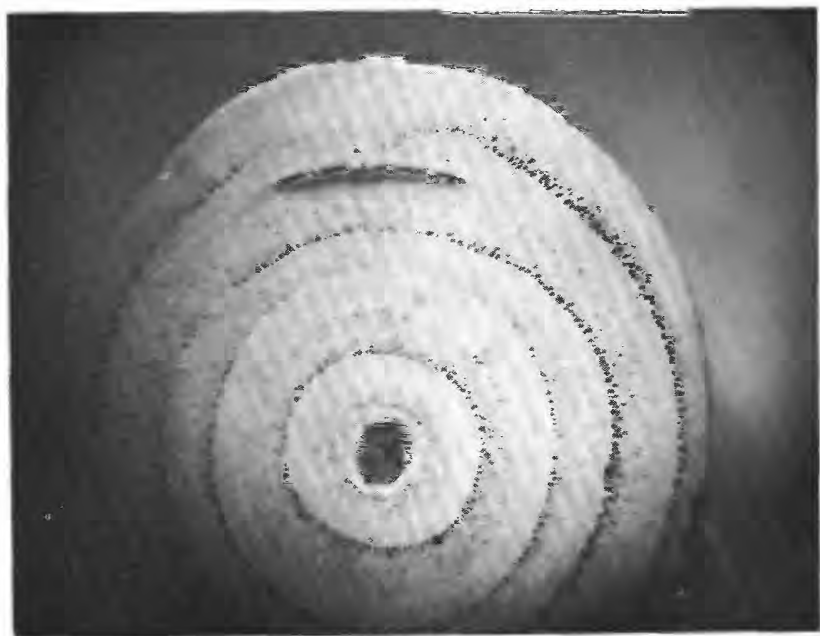

$D$

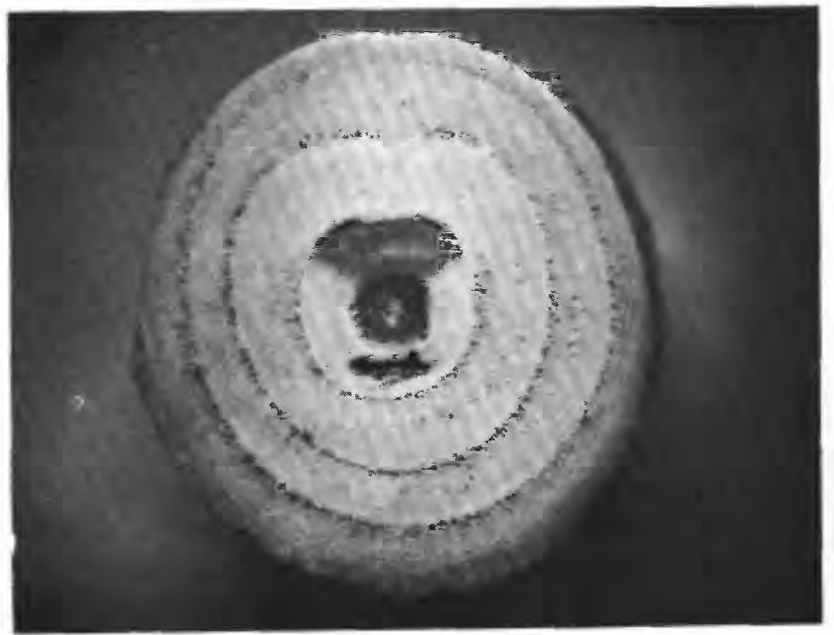

$F$

Frgure 10.-Cross sections through stem shown in figure 8. The dark dots are large vessels formed during early growth in the spring. One annual ring consists of a ring of vessels and the more or less even-textured wood extending outward to the next ring of vessels. In all sections the outer ring was formed in 1957. The outermost tissue, seen only at the bottom of the sections, and especially in $F$, is bark; it was abraded from the other side of the stems by the ice. The diameter of the section in $A$ is $11 / 2$ inches. 
that fast-growing sprouts started to grow from the bent trees and stumps during the following summer. They observed before 1959 that trees on the lower surfaces of the Wabash River flood plain showed the effects of what they believed to be periodic ice damage.

Many years after a flood, sprout trees can be recognized as one or more trunks growing from a common root stock. The old stump can be seen at the base of the sprouts; or with a little digging in the center of the area surrounded by the circle of sprouts, rotten wood can be turned up; or the sprouts may appear as closely grouped trunks, seemingly growing out of the ground, until an excavation around them reveals that they are all connected to the same root system. Such stumps have been buried by alluvium deposited during subsequent floods. This growth form cannot be distinguished with certainty from sprouts growing from

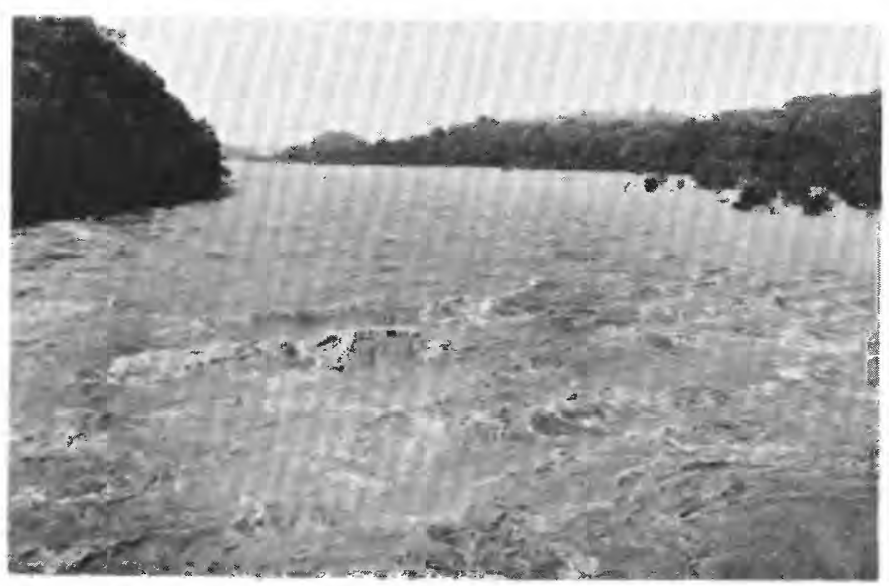

Figdre 11.-Potomac River on August 20, 1955. View is in upstream direction from Chain Bridge. Flood peak discharge was $216,000 \mathrm{cfs}$ at $2: 30$ p.m. Maximum depth of the water here above low flow is about 35 feet. Photograph by Abbie Rowe, National Park Service.

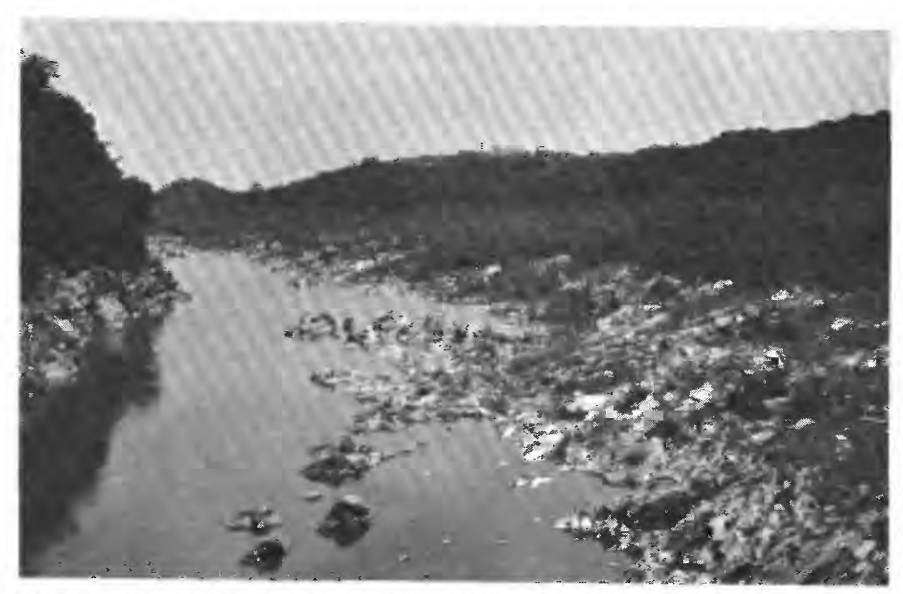

Figdre 12.-Potomac River, viewed in upstream direction from Chain Bridge, at low flow, Jume 1956. Two fishermen can be seen standing on a rock to the left of center. This point is just upstream from the large waves in the center of figure 11 .

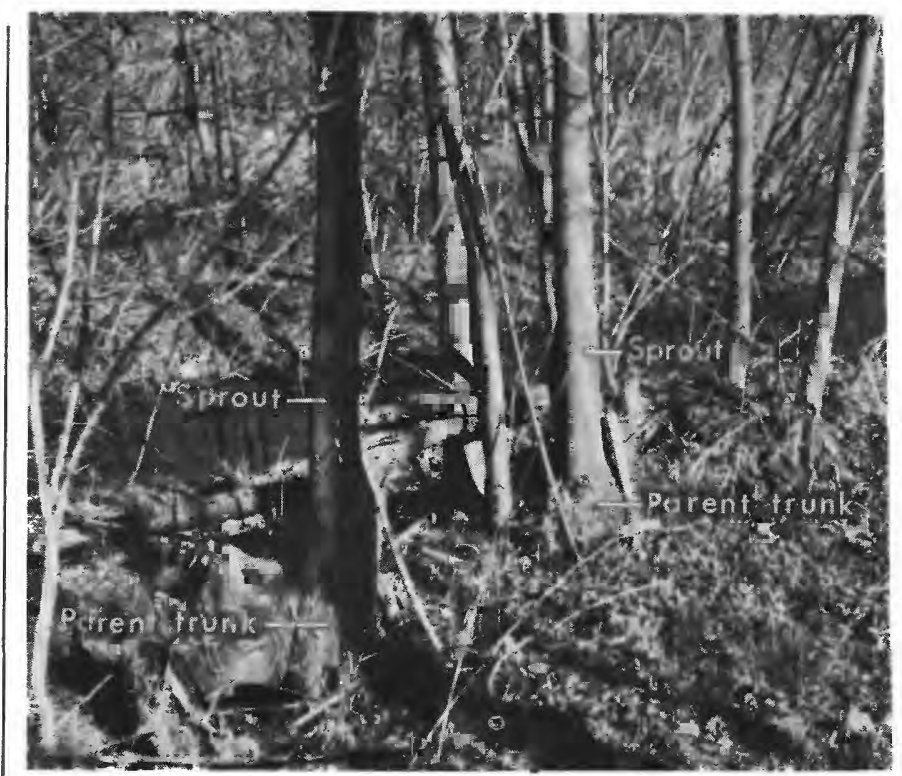

Figure 13.- Sprouts from stump cut off by an ice jam on February 16, 1948.

a sawed stump; but sprouts growing from rotten stumps in a flood-plain area, in which many trees of the same age are sprouts growing from inclined trunks, probably date from a severe flood.

More commonly, flood-plain trees that have been damaged by high water are partly uprooted or bent over, and the subsequent form consists of vertical sprouts from an inclined trunk (fig. 18). Just as a scar on the side of a trunk can be dated by counting the rings overlying it, so can the year that a tree was felled be determined.

The simple form consists of a vertical sprout growing from an older inclined trunk. The roots are upstream and the trunk is inclined in a downstream direction. In line with the axis of the inclined trunk and at the extreme downstream side of the tree, the stub of the parent trunk consists of a protrusion of rotten wood that may be only partly covered with wound tissue (fig. 14). The vertical sprouts start to grow from the inclined trunk during the first growing season after the tree was felled; thus, a count of the annual rings in a core from the base of the sprout that includes the outer- and inner-most rings tells the number of growing seasons since the tree was knocked down.

The bark of the older inclined trunk is rougher, the scales or plates are larger, and ridges and grooves are deeper than are those of the sprout. The inclined trunk looks more mature than the sprout, and the two invariably have a visible line of demarcation between them. The L-shaped form and differences in texture of the bark persist for a long period of time (fig. 15). 


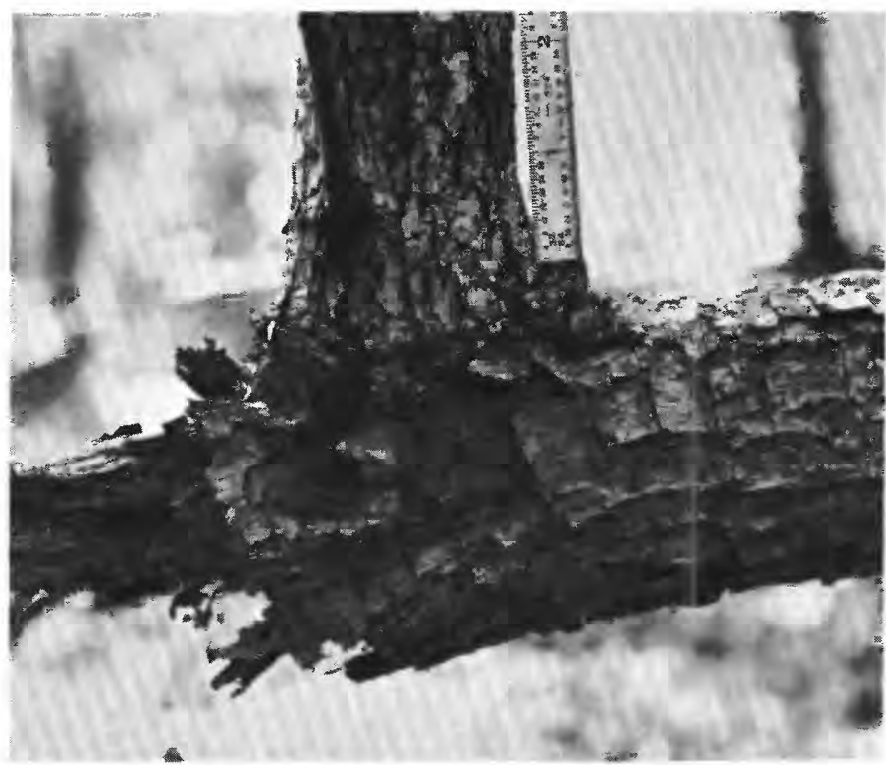

Figure 14.-Vertical sprout growing from inclined trunk, showing stub of rotten wood at end of parent trunk that was felled by 1948 ice jam. Difference in texture of bark of sprout and of trunk and line between them are apparent. Downstream is to the left.

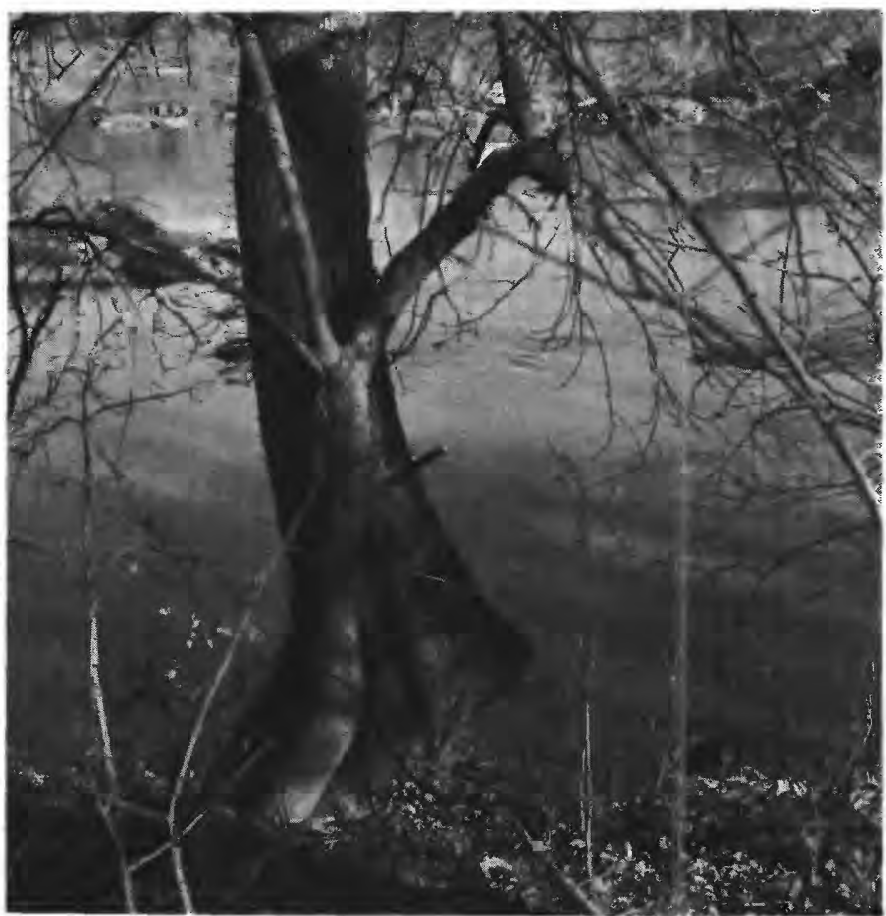

FIGURE 15.-Trunk of tree that has sharp angle near its base suggesting origin as a sprout from the part inclined in a downstream direction to the right. Trunk above angle started to grow in 1861 .

Damage from several floods can be seen in the sequential composition of occasional trees: sprouts arising from older, inclined sprouts which in turn arise from the inclined parent trunk (fig. 16). The history of the ash tree illustrated in figure 16 is shown diagrammatically in figure 17 and indicates by way of a case study how botanical evidence of floods can be interpreted from sprouted, flood-felled trees. The two oldest sprouts started to grow in 1930, the first growing season after a flood in October 1929. In the summer of 1929, the tree was probably fairly small and probably consisted of a single vertical trunk. Floods occurred on April 18 and October 23, 1929, prior to the construction of the stream gage near Washington, D.C. From the record of the Point of Rocks gage, 41 miles upstream, I estimated that the discharge at Chain Bridge during these floods was 190,000 cfs and 125,000 cfs. Both, though not large, would have covered the tree and could have damaged it.

Evidence that the 1929 floods damaged this tree is somewhat questionable; however, the evidence of subsequent floods is more reasonable. The sprouts that started to grow in 1930 were, by the autumn of 1942 , small trees having trunks about 5 inches in diameter. On October 17, 1942, the second highest flood of record crested and bent the tree in a downstream direction.

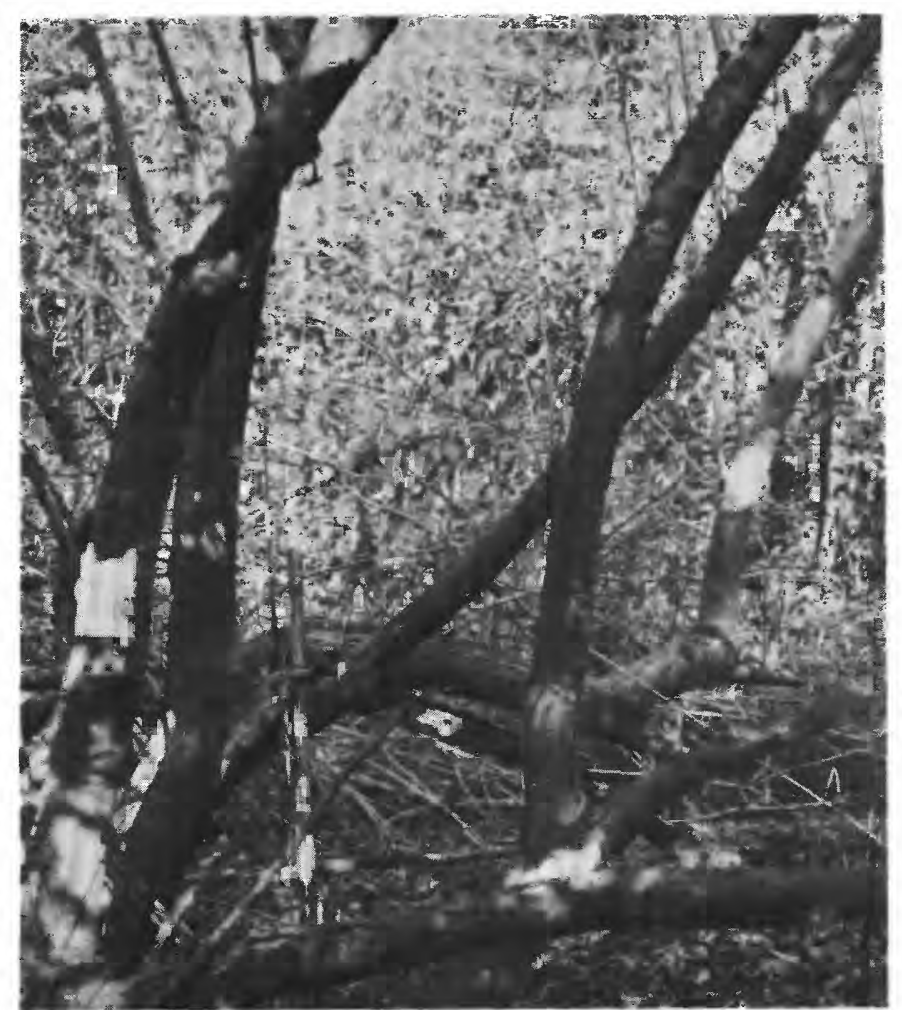

FigUR 16, - Ash sprouts of four ages growing from a stump, to the left out of the photograph, on the Potomac River flood plain near Chain Bridge. The smallest sprouts, in upper half of photograph, are nearly vertical and started to grow in 1956. Second-age sprouts, shown forming a gentle arc and inclined to the right at about $70^{\circ}$ from the horizontal, started to grow in 1948. The third-age sprout, the short segment in lower third of photograph, is inclined to the right at about $25^{\circ}$ from the horizontal and is growing from a convex split trunk; this sprout started to grow in 1943. The oldest sprouts are a pair that started to grow in 1930 . 

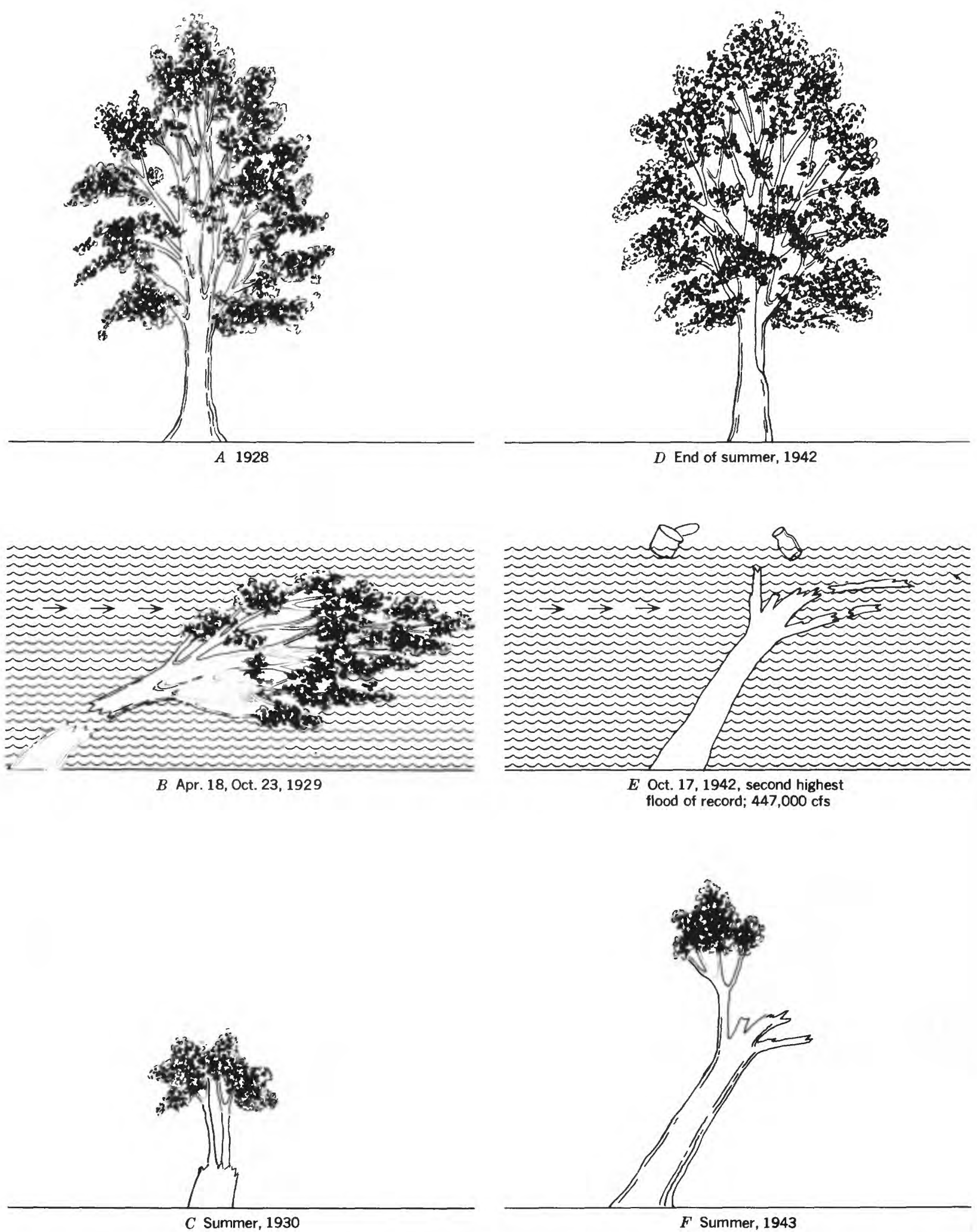

FIGURw 17.-Diagrams showing events that produced the form of the ash tree illustrated in figure 16. 

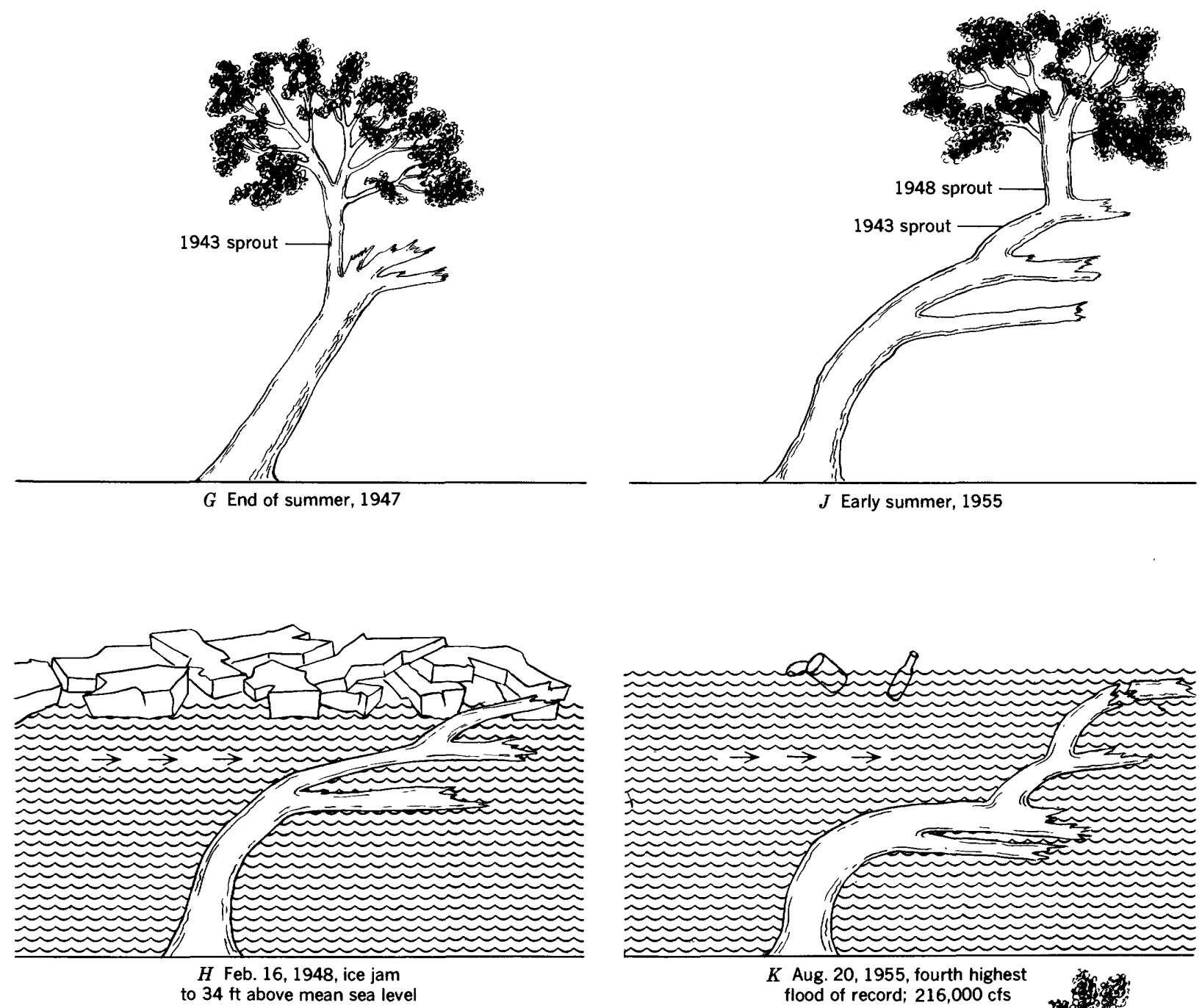

to $34 \mathrm{ft}$ above mean sea leve
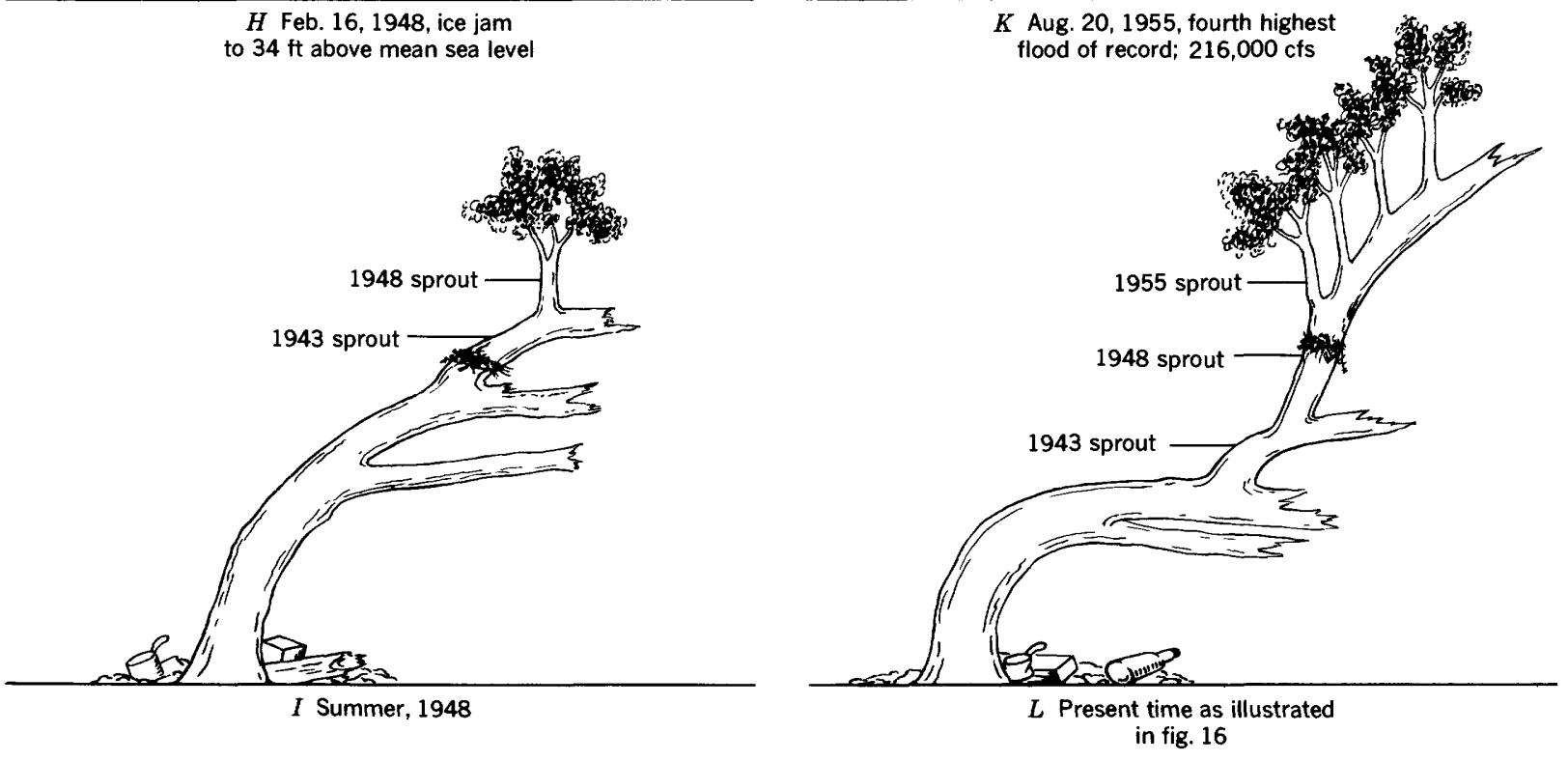

Two sprouts that started to grow in 1930 persist today; but, for simplicity, only one is shown. 
A sprout started to grow in 1943. By the end of the summer of 1947 , this sprout was about 1.5 inches in diameter and was bent over or decapitated by the ice jam on February 16, 1948. From this inclined sprout a new sprout started to grow in 1948 and by August 20, 1955 , the new sprout was about 1.5 inches in diameter when it was bent over by the fourth highest flood of record.

The fact that evidence of the maximum flood of record, on March 19, 1936, and of the third highest, on April 28, 1937, is missing in this tree points out a major problem in using botanical evidence for recreating a flood history. This tree shows certain evidence of three floods; but like any other one specimen; it cannot be expected to yield information on all floods that inundated it during its lifetime. Chance alone can explain why a single tree escaped injury, or the 1942 flood and the 1948 ice jam could have destroyed evidence of earlier floods. The most abundant evidence that has been found in this study stems from the most recent floods. Either other floods which are known to have occurred did not damage trees that show evidence of earlier and later inundation, or the later floods destroyed the earlier evidence.

Evidence of nearly every flood on the Potomac River in the vicinity of Washington, D.C., since the flood of 1936 has been found along a reach extending about a mile upstream and a mile downstream from Chain Bridge. Single sprouts of several ages from inclined trunks have been found that date from floods that occurred prior to the period of record. These single sprouts only suggest earlier floods and, in the absence of other evidence, do not date them. If many sprouts of the same age were found, however, they would be offered as proof. The upright trunk of the larger tree shown in figure 15 started to grow in 1861. Sanderlin (1946, p. 220) stated that a "freshet" in April 1861 was reported to have damaged the Chesapeake and Ohio Canal that borders the river. Sprouts of two trees upstream from Great Falls started to grow in 1889, and the maximum flood prior to 1936 occurred in May and June 1889 (Grover, 1937, p. 334). Grover (1937, p. 334) listed another flood in February and March 1902 for which botanical evidence has also been found. In the vicinity of Chain Bridge, a sprout was found that started to grow in 1924. A severe flood occurred on May 13, 1924, that was reported to have overflowed the Chesapeake and Ohio Canal levee for a distance of 1 mile in the vicinity of Chain Bridge (The Washington Post, May 14, 1924). This flood caused such heavy damage throughout the length of the canal that the Canal Company failed to recover, and traffic on the canal finally ended (Sanderlin, 1946, p. 277-278).

\section{GROWTH OF TREES FOLLOWING BURIAI BY AILUVIUM DURING FLOODS}

The sediment carried by a flood accumulates in places on the flood plain where it may surround the bases of some upright tree trunks or partly cover water-felled trees, giving both a characteristic appearance which can be easily recognized. If a tree remains buried through at least one growing season, ring counts and study of wood structure made in the laboratory can determine with accuracy the year in which the burial took place.

Trees that grow on fairly stable surfaces have a characteristically flared base, which is buried when the upright trees are subject to aggradation during a flood. Such partly buried trees look like poles or posts stuck in the ground. Hadley $(1960$, p. 14) noticed this form in trees on flood plains in the Cheyenne River basin in Wyoming and interpreted it as an indication of active aggradation. Jahns (1947, p. 98) learned that the minimum thickness of recent flood-plain sediments could be determined by the depth of buried tree trunks.

Digging around the base of a buried tree will expose the roots and may show the flared base that was once above the ground surface. The buried, flared base suggests that the tree grew during much of its life while little or no sediment was deposited around it, and the sediment now above the flared base suggests that aggradation was recent and heavy (fig. 18A). A rounded or inverted cone-shaped base on a buried tree, on the other hand, may indicate that aggradation occurred early in the life of the tree, before a flared base could form, and that aggradation has continued at repeated intervals (fig. 18B). The relationship of the shape of the base to the rate of deposition has not been demonstrated in the field; but a number of individual trees of the same species having the two forms have been found, suggesting the postulated formation.

Felled trees, buried or partly buried by alluvium, develop one or more vertical sprouts on the upper side of the part of the inclined parent trunk that protrudes from the ground. This trunk, like those of all water-felled trees, is alined nearly parallel to the direction of streamflow (fig. 19). Sometimes only a row of sprouts or young trunks is visible because the parent trunk is completely buried.

Since many living trees of all flood-plain species have been found partly buried in the Potomac River flood plain, it is apparent that severe damage and burial are not necessarily lethal. Adventitious roots commonly start to grow from the buried part of the trunk from tissues, which Eames and MacDaniels (1947, p. 289) called root germs, located close to the vascular cambium. Kramer and Kozlowski (1960, p. 391) pointed out that roots grow from branches still 


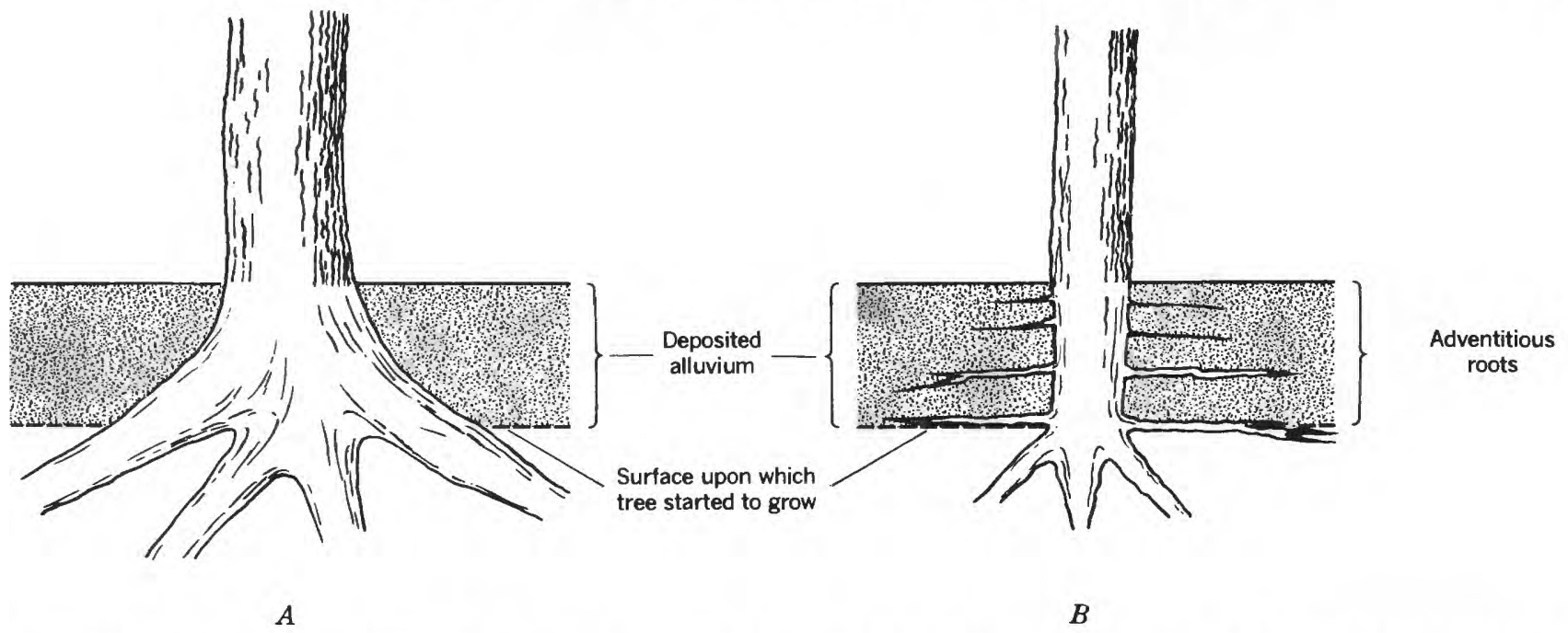

FiguRE 18.-Diagram showing forms of tree bases postulated as result of different rates of deposition. A, Flared base suggests recent and heavy deposition; $B$, inverted cone-shaped base suggests early and repeated deposition.

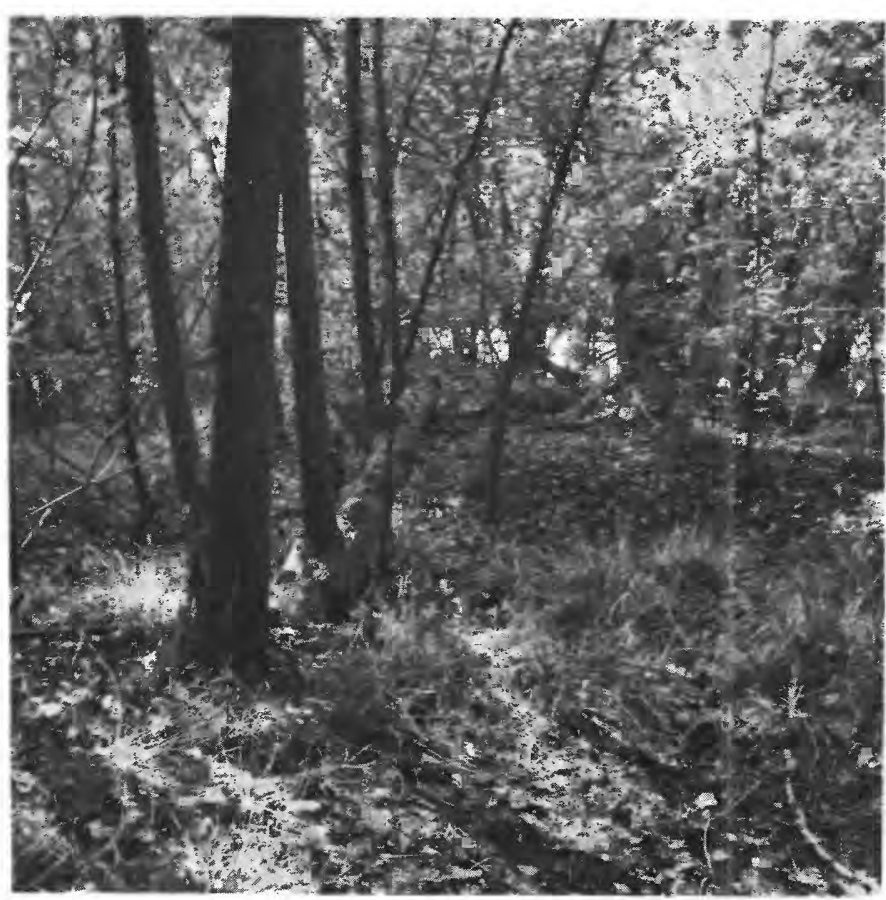

$A$

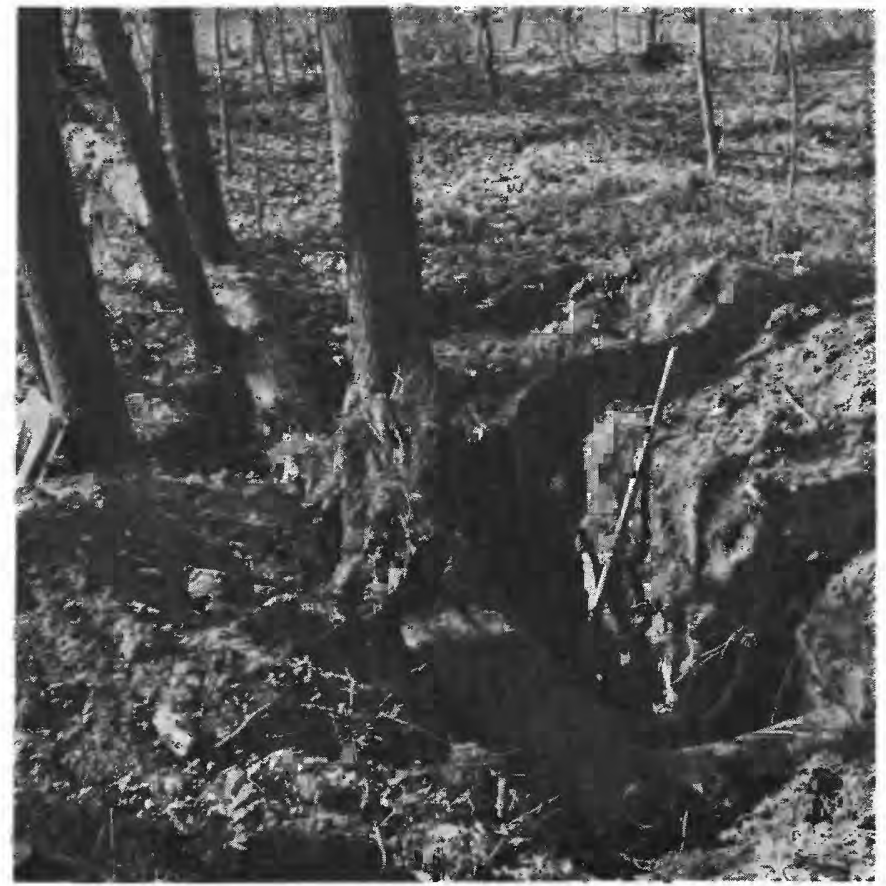

B

Figure 19.-Ash tree partly uprooted prior to growing season of 1936, probably during flood of March 19 , 1936 , the maximum flood of record. $A$, Tree, showing parent trunk protruding from flood plain in downstream direction and three vertical sprouts; $B$, exposed buried trunk, showing flared base. Shovel is $4 \frac{1}{2}$ feet long; point rests about 1 foot below the approximate level of the flood plain prior to 1936.

attached to trees when the branches come into contact with moist soil.

In the area studied along the Potomac River, I have not discovered any trees that were killed by deposition of sediment as great as 3 feet deep; but Harper (1938, p. 47) found that thick deposits of alluvium resulted in poor drainage which killed trees along Deep Fork of North Canadian River in Oklahoma; he attributed the heavy sedimentation to straightening and dredging of an upstream reach of the channel. Featherly (1941) noted that deposition of alluvium to depths of as much as 10 feet in Oklahoma killed mature forest trees; however, he found a small ash tree that started to grow in 1928 and that, by 1940, it was still alive in spite of the 52 inches of sediment deposited around it. Cottonwood, willow, baldcypress, and tupelo trees survive 
heavy siltation on flood plains in the lower Mississippi River valley (Putnam and others, 1960, p. 20).

The approximate level of the surface upon which partly buried water-felled trees were growing before being uprooted is determined by interpolating the level of the flared base by figuratively rotating the parent trunk to a nearly vertical position. Application of this system to the tree represented in figure $19 B$ shows that about $2 \frac{1}{2}$ feet of alluvium lies above the original base level. The fact that the vertical sprouts started to grow in 1936 indicates that the tree was uprooted during the flood of March 19, 1936. The alluvium has been deposited since then.

\section{ANALYSIS OF STRUCTURE OF WOOD FROM BURIFD} TRUNK

Because the wood formed in the buried part of the trunk after burial has a structure different from that formed prior to burial, the year of deposition can be determined. Other investigators have found by both experimentation and observation that wood formed in buried or submerged stems structurally resembles the wood of roots. Bannan (1962, p. 15), citing Wieler, stated that wood of the kind found in lateral roots can be produced in a stem by placing it under water. In anatomical studies of stemgrafts in fruit trees, Beakbane (1941, p. 361) showed that some characteristics of the wood in a stem grown below the ground closely resembled those of root wood; other characteristics were intermediate between those of stems and roots. Wood in the swelled butts of ash trees growing in wet swamps is less dense than wood higher in the trunks, and the cells of the wood in the butts are larger (Koehler, 1933, p. 14-15). Pillow (1939, p. 135-136) found that wood of low density extends farther above ground in deeply flooded trees than in shallowly flooded ones.

The method of study and analysis of data used to determine the sedimentation history of buried trees was developed from data collected from an ash tree close to the one shown in figure 19. The site on which these trees grow has been covered by high water at least 26 times between March 19, 1936, and May 10, 1960, and the tree in figure 19 has probably experienced a complex history of alternate burial and exhuming in these 24 years. The tree used to develop the method, however, was merely felled during one flood and buried during another. Its history has been simple. The tree is on the east side of Conn Island approximately 1,000 feet upstream from Washington Aqueduct Dam in Montgomery County, Md. The surface around it has an elevation of $\mathbf{1 5 6}$ feet and is approximately 3.5 feet above low water, which is controlled by the dam.
The surface around the tree was just covered by the peak flow of $82,100 \mathrm{cfs}$ on May 7, 1958. This discharge has a recurrence interval of 1.25 years, based on the annual flood series. The water was about 1 foot deep during the crest on May 10, 1960, which had a peak discharge of $124,000 \mathrm{cfs}$ and a recurrence interval of 1.9 years.

The tree (figs. 20, 21) consisted of a parent trunk that was almost completely embedded in alluvium and a nearly vertical sprout growing from its extreme downstream end. As the sprout started to grow in 1936, the tree must have been felled during the March 19, 1936, flood. Another sprout, already dead and buried when dug, had grown from near the parent base; therefore, the tree was not buried when it was felled. The level of the base shows that about $2 \frac{1}{2}$ feet of sediment was deposited on the flood plain during one or more of 25 floods after March 19, 1936, and before November 25, 1957, when the tree was studied. In the paragraphs that follow, it will be shown that the tree was buried in 1937, 1 year after it was felled, and that no significant amount of sediment has eroded subsequently from around the tree.

To determine when the tree was buried, a laboratory study was made of cores taken from the parent trunk at 1-foot intervals ("C" in fig. 21) from the base of the sprout, at ground level, to the previously buried base. Microscopic examination of each core showed that the wood lying outside one particular annual ring is softer and more even textured than the wood toward the center from the ring. The ring that marked the change could not be dated directly in each core because some rings, especially those near the outer part of the trunk, are indistinct; so the ring was cross-dated with those in the core taken at the ground surface. The distinctive wood was first formed in 1937 throughout the length of the buried trunk. The third highest flood of record occurred on April 28 of that year.

A large wood sample was taken from the buried trunk $21 / 2$ feet from the vertical sprout and approximately $11 / 2$ feet below the surface of the ground. Diameters of 1,100 vessels in 11 selected rings, dating from 1930 through 1946, were measured in a prepared cross section that included rings formed in 1936, 1937, and 1938.

The data show that the relative diameters of the vessels in the ring that grew in 1937 and in rings that grew in later years were different from the relative diameters of the vessels in rings that grew before 1937 . As illustrated in figure 22, the early wood vessels are smaller and late wood vessels are larger in the 1937-40 rings than the corresponding vessels in the 1934-36 rings. When the difference in the mean diameters of 
early wood vessels and late wood vessels of 11 selected rings dating from 1930 through 1946 was calculated, and when the ratio of this difference to the mean of the early wood vessels was determined and plotted for each,

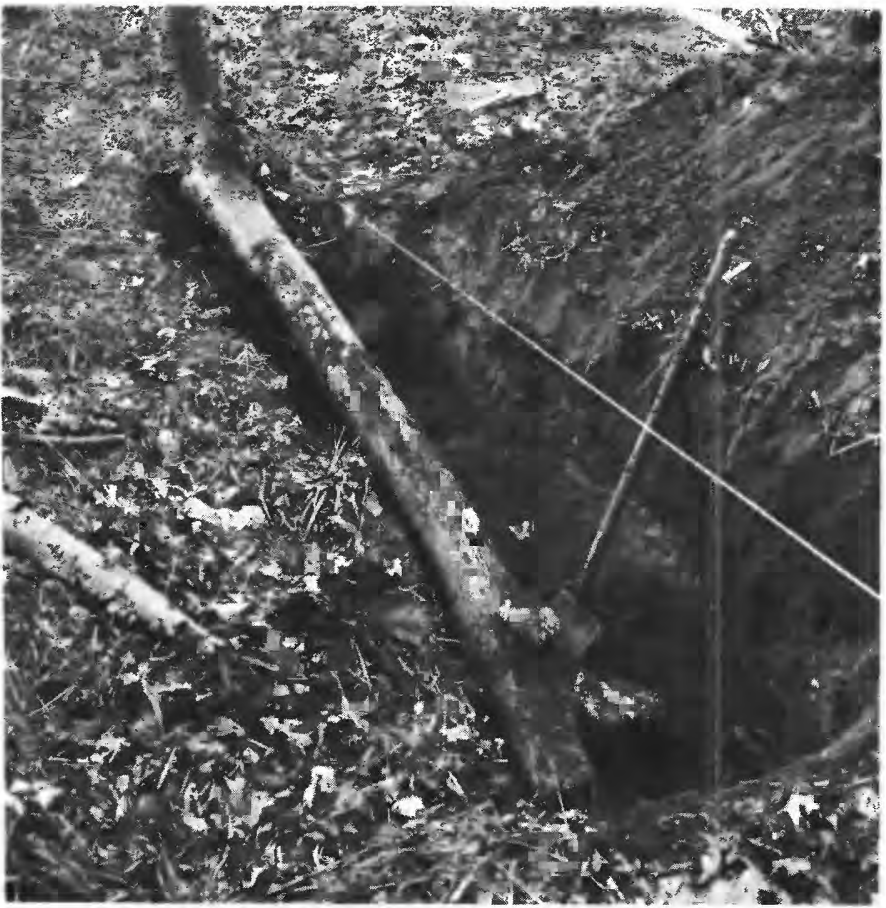

FIGURE 20.-Ash tree, showing inclined buried trunk and nearly vertical sprout. Burled dead basal sprout is barely visible to the left of the shovel. White line is horizontal, and shovel is $4 \frac{1}{2}$ feet long. ring (fig. 23), it could be seen that the major change in the difference in mean diameters occurred in 1937.

Statistical analysis of these data shows that the vessels formed after 1936 are significantly different in diameter from those formed before 1936. The mean diameters of the late wood vessels of rings formed from 1930 to 1936 were compared with those of late wood vessels formed from 1938 to 1946. Early wood vessel diameters were similarly compared. The means of the two types of vessels formed in 1937 also were compared with the means of the earlier rings and of the later rings. The assumption was made that the vessel diameters are samples of a normal population. The results are summarized on page $\mathrm{A} 22$.

The $t$-test, which is a measure of the deviation of the mean of a sample from that of the population, indicates that the vessels in rings formed from 1938 through 1946 have less than a 0.25 percent chance of being similar to vessels in rings formed from 1930 through 1936; in other words, there is 1 chance out of 400 that the vessels of the two groups of years are similar. The analysis of the early wood vessels in the 1937 ring further shows that there is about a 90 percent probability that these vessels are similar to those in rings formed later, whereas there is only about a 5 percent probability that they are similar to those formed earlier. These analyses support the hypothesis that the tree was buried in 1937.

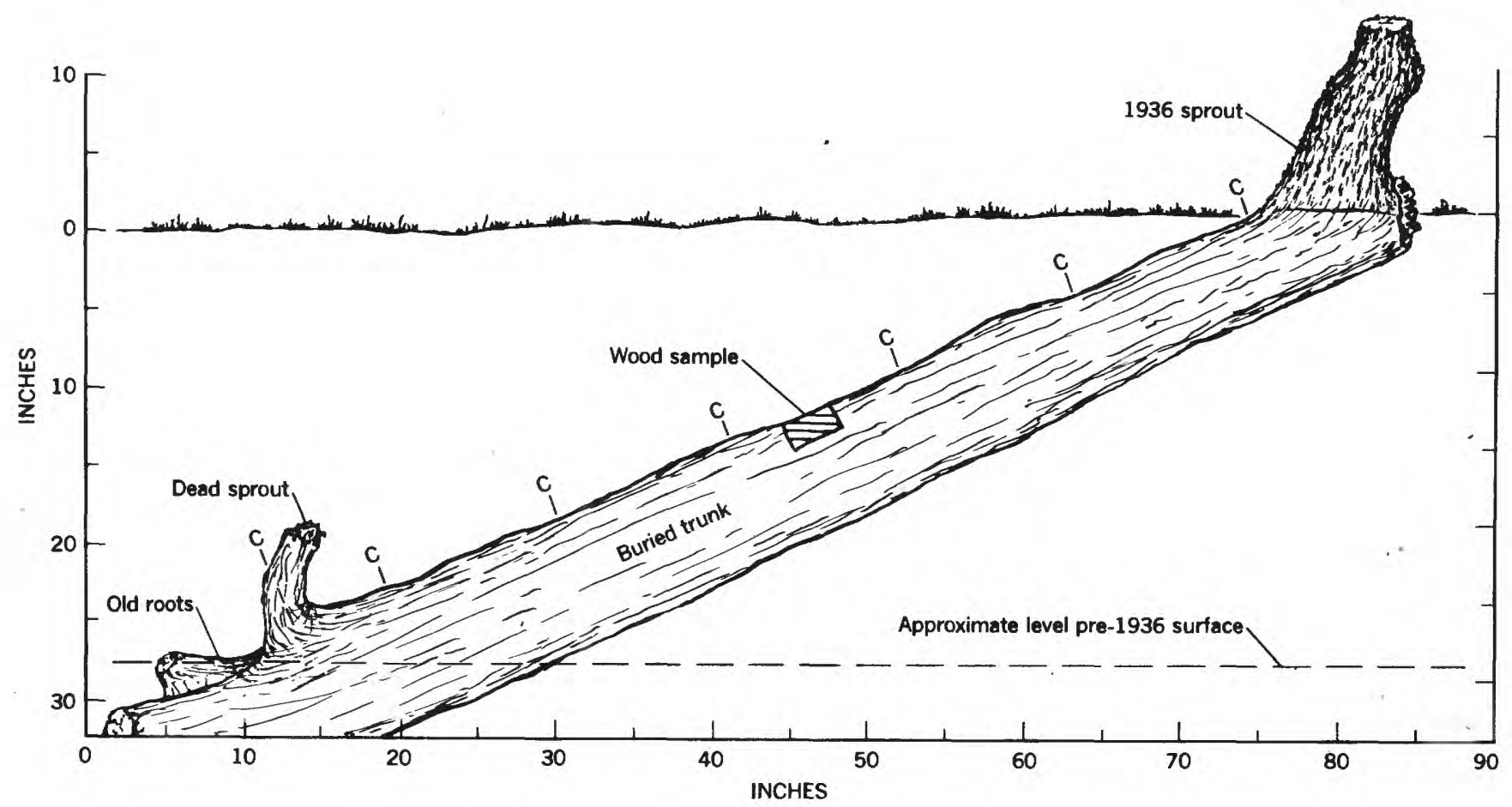

FIGURE 21.-Drawing of ash tree, showing basal sprout, location of cores $(C)$ and wood sections, and approximate level of flood plain prior to 1936. 


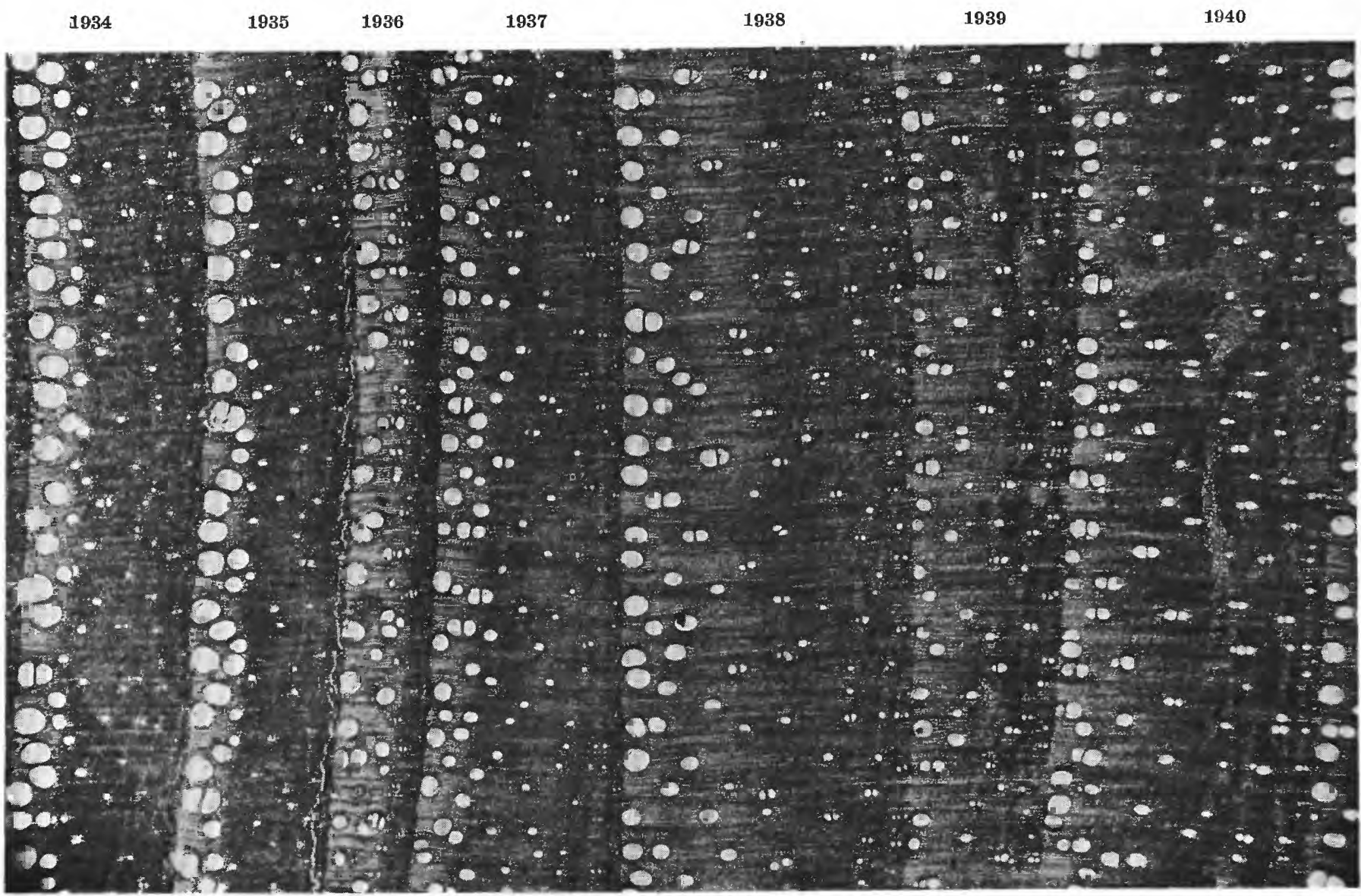

Figure 22.-Photomicrograph of wood from buried trunk of ash tree, showing that the early wood vessels are smaller and the late wood vessels are larger in 1937-40 rings than in 1934-36 rings. Early wood vessels are the larger white ovals on left side of each ring.

Comparison of vessel diameters-summary Late Wood Vessels

\begin{tabular}{l|c|c|c}
\hline & $\begin{array}{c}\left.\text { Group 1 ( } x_{1}\right) \\
1930-36\end{array}$ & $\begin{array}{c}\text { Group 2 }\left(x_{2}\right) \\
1938-46\end{array}$ & 1937 \\
\cline { 2 - 3 } Mean__. & $\begin{array}{c}.0489 \\
.0000477\end{array}$ & $\begin{array}{c}0.0873 \\
.0000489\end{array}$ & 0.0653 \\
\hline
\end{tabular}

Probability $\left(\bar{x}_{1}=\bar{x}_{2}\right)(t$-test; $t=8.727,8$ degress of freedom) $\leq 0.25$ percent.

Probability 1937 belongs to Group $1<2$ percent.

Probability 1937 belongs to Group $2<2$ percent.

\begin{tabular}{l|c|c|c}
\hline \multicolumn{3}{c}{ Early Wood Vessels } \\
\hline & $\begin{array}{c}\text { Group 1 }\left(x_{1}\right) \\
1930-36\end{array}$ & $\begin{array}{c}\text { Group 2 }\left(x_{2}\right) \\
1938-46\end{array}$ & 1937 \\
\hline Mean & $\begin{array}{c}0.2243 \\
.000651\end{array}$ & $\begin{array}{c}0.1720 \\
.000258\end{array}$ & 0.1742 \\
\hline Variance 000
\end{tabular}

Probability $\left(\bar{x}_{1}=\bar{x}_{2}\right)(t$-test; $t=3.874,8$ degrees of freedom) $\leq 0.25$ percent.

Probability 1937 belongs to Group $1 \cong 5$ percent.

Probability 1937 belongs to Group $2 \cong 90$ percent.
Study of the buried sprout that was dead when the tree was dug (figs. 20, 21) supports the thesis that the tree was buried after the growing season of 1936 and not when it was knocked over, prior to this growing season. The sprout, which started to grow when the tree was felled, must have begun life as a stem, rather than as a root, for it has pith at the center-roots do not contain pith; therefore, the part of the tree from which the sprout arose was not buried at the time the sprout began to grow. The inner ring of the sprout is composed of wood similar to that found in a stem, but wood toward the outside is more like that in roots. This sprout must have started to grow after the tree was knocked over, while the base was still above the ground surface, and must have continued to grow for a time after the tree was buried.

By way of summary, then, the tree was knocked over in 1936, and two sprouts grew from the inclined trunk: one from the base and one from the distal part. In April 1937 the tree was buried, and the wood that 
formed in the buried trunk contains vessels that are different from those formed in 1936 and earlier. The vessels formed in 1937 are like those that formed later, and their size distribution is similar to that of vessels formed in root wood.

\section{EVIDENCE OF FLOODS AND DEPOSITION IN TREES ALONG SMALL STREAMS}

The trees described in the preceding section are growing along the Potomac River, where large floods innundate the flood plain for several days and to depths exceeding 10 feet at the peak. Floods of this duration and magnitude commonly fell large trees. On small streams, on the other hand, evidence of floods in the form of sprouted inclined trunks indeed is rare. A measure of the effective force necessary to abrade bark or to uproot trees has not been devised but seems to be related to the depth and velocity of the water and to the duration of innundation in relation to the size of the tree. Floods on small streams are generally of shorter duration, and depths over the flood plain at the peak are lower than on large rivers. As a flood progresses downstream, in other words, the flood wave spreads out (Hoyt and Langbein, 1955, p. 38, 40), and the lag in time between the occurrence of the storm and the passage of the flood crest becomes longer. All other factors being equal, the peak discharge varies almost directly with the size of the drainage area or the size of the stream (Benson, 1962b, p. B53). Although the relative quantities of sediment transported during floods of different frequencies can be used as a measure of the effectiveness of floods (Wolman and

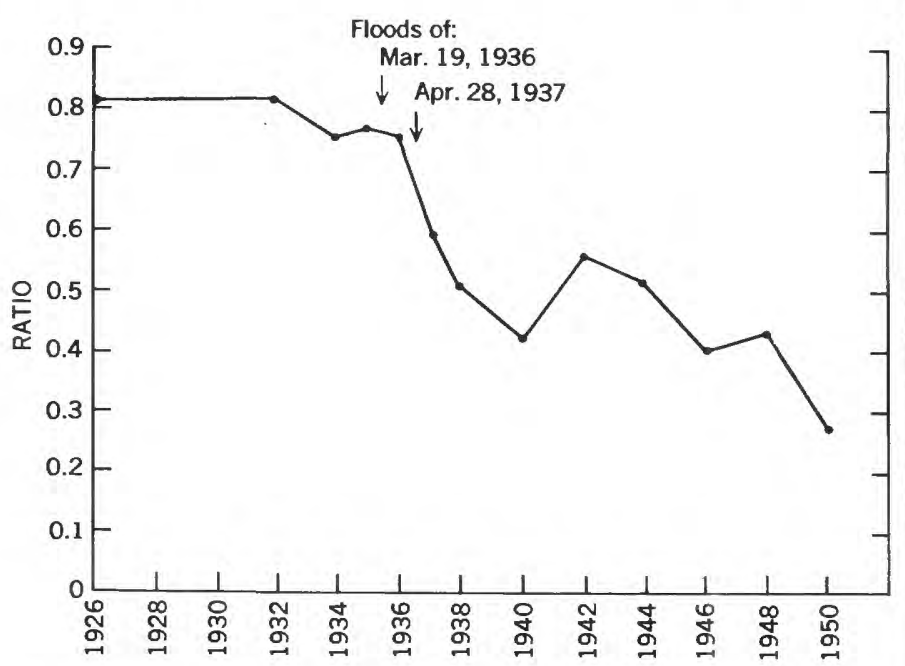

FIGURE 23.-Ratio of difference between mean of eariy wood and late wood vessel diameters to the mean early wood vessel diameters for selected years. The points represent the end of the growing season for the respective years, and the line between them the period from the end of one growing season to the end of the next. Largest difference between ratios of successive years is between 1936 and 1937.

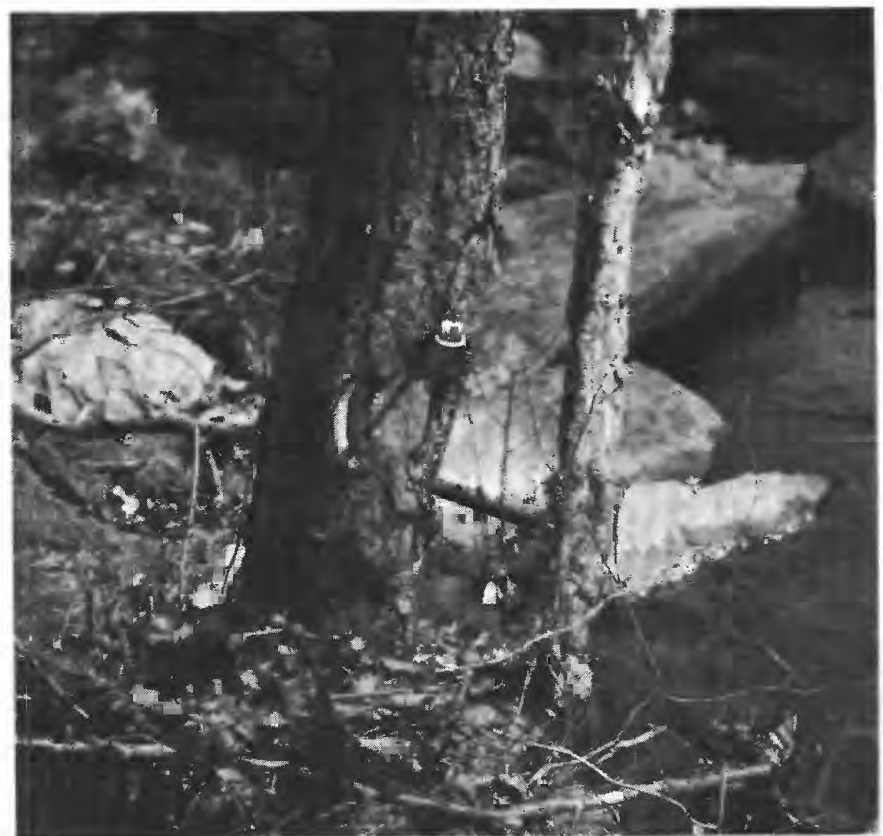

Figure 24. - Scar on channel side of river birch on Difficult Run, Va. Scar was formed before 1959 growing season and abraded again before the 1961 growing season.

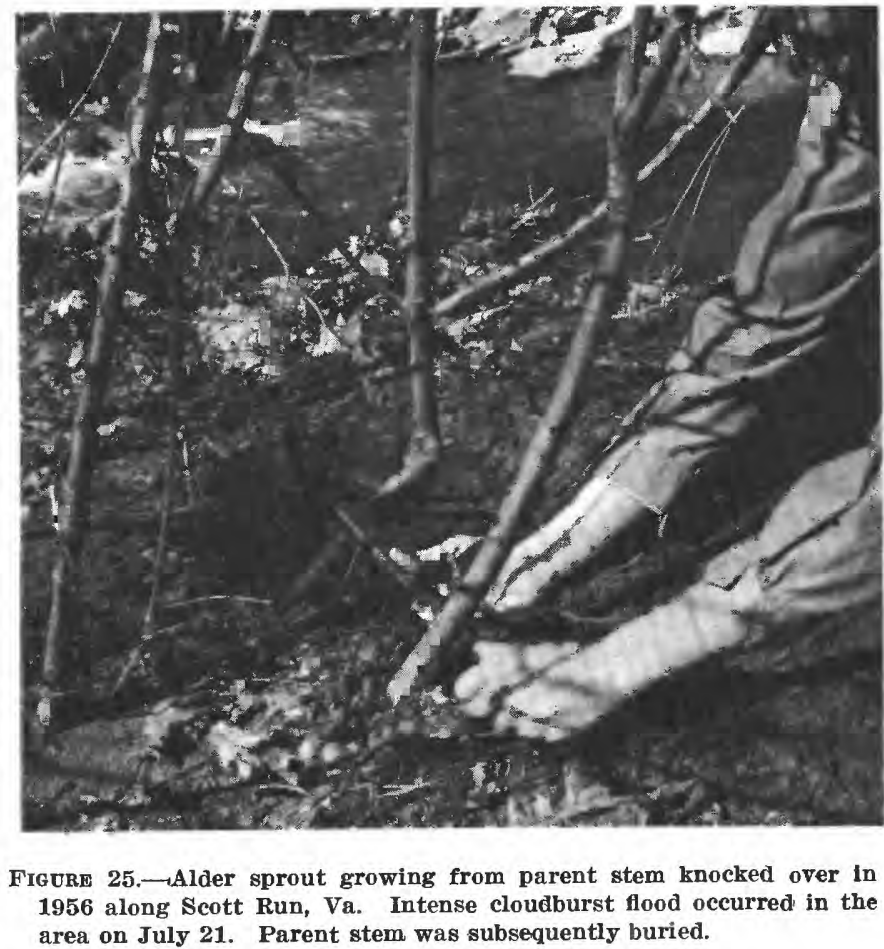

Miller, 1960, p. 55), they do not qualify as a measure of the relative effect of floods upon trees.

The same type of evidence of floods and flood-plain deposition described in this report from data collected from trees along the Potomac River has also been found in small trees and shrubs growing on the flood plains of four small streams in Fairfax County, Va., 


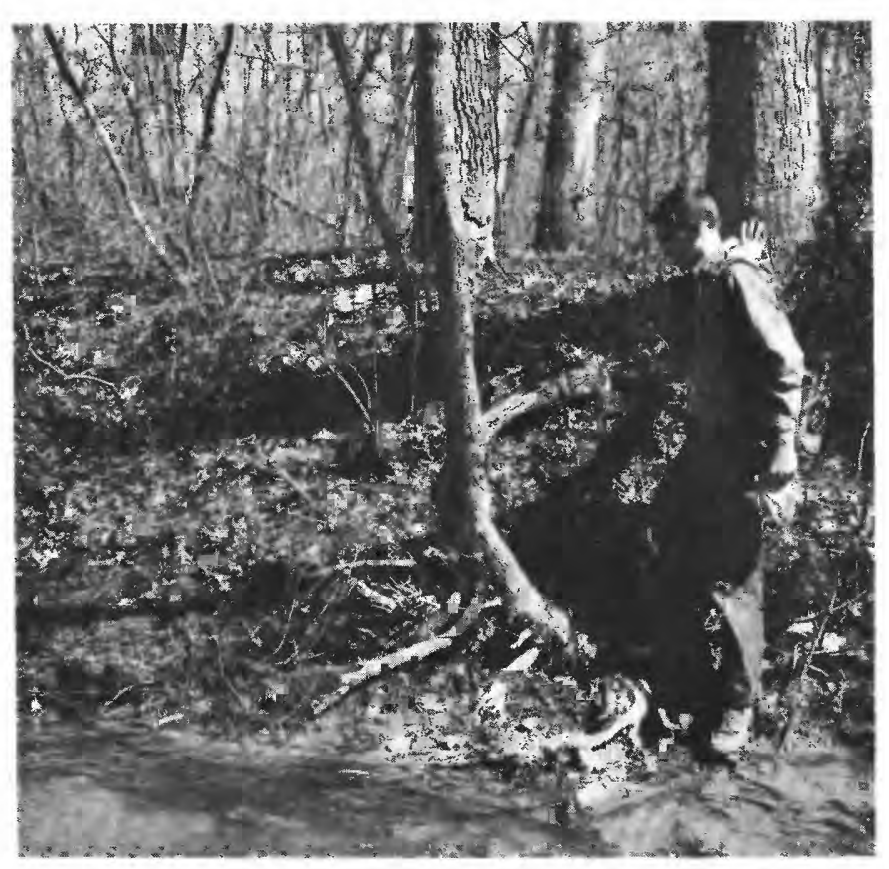

Frgore 26.-Ash sprout growing from inclined trunk that was knocked over by flood prior to 1928 growing season along Scott Run, Va.

and Montgomery County, Md. (figs. 24, 25). In 43 specimens collected along these streams, 35 scars or sprouts were found that are related to recorded floods. Growth after 11 floods started prior to the period of record on the stream where the evidence was found. One tree consists of a sprout that started to grow from an inclined trunk knocked over prior to the 1928 growing season (fig. 26).

One small tree (fig. 27), collected by D. G. Anderson on Tripps Run, Fairfax County, Va., was studied intensively and shows evidence in the wood structure and growth form of partial burial on two occasions and of felling on two more. This damage occurred prior to the period of record on Tripps Run. The discharge of two floods was determined on nearby streams. These floods occurred during years when the tree was partly buried and partly felled. The data from the trees on small streams are summarized as follows:

Damage to trees on flood plains of small streams as related to floods

\begin{tabular}{|c|c|c|c|c|c|c|}
\hline Stream & $\begin{array}{c}\text { Drain- } \\
\text { age area } \\
\text { (sq mi) }\end{array}$ & $\begin{array}{l}\text { Period } \\
\text { of record }\end{array}$ & $\begin{array}{l}\text { Number } \\
\text { of speci- } \\
\text { mens }\end{array}$ & $\begin{array}{c}\text { Number } \\
\text { of scars } \\
\text { related } \\
\text { to flood } \\
\text { record }\end{array}$ & $\begin{array}{l}\text { Number } \\
\text { of scars } \\
\text { formed } \\
\text { before } \\
\text { record }\end{array}$ & $\begin{array}{c}\text { Number } \\
\text { of scars } \\
\text { of ques- } \\
\text { tionable } \\
\text { origin }\end{array}$ \\
\hline Difficult Run, $\mathrm{Va}_{-}$ & \multirow{5}{*}{$\begin{array}{l}58 \\
4.69 \\
4.55 \\
4.1\end{array}$} & \multirow{5}{*}{$\begin{array}{r}12 / 34- \\
9 / 57 \\
8 / 60- \\
3 / 12 / 63 \\
9 / 59- \\
3 / 12 / 63 \\
6 / 44- \\
5 / 63\end{array}$} & 11 & 14 & \multirow{4}{*}{7} & 2 \\
\hline Scott Run, Va_..... & & & 5 & 1 & & \\
\hline Tripps Run, Va_..... & & & 8 & 6 & & \\
\hline Little Falls Branch, & & & 19 & 14 & & \\
\hline Total & & & 43 & 35 & 11 & 2 \\
\hline
\end{tabular}

\section{EVIDENCE OF SEQUENTIAL DEPOSITION AND EROSION ON THE FLOOD PLAIN}

The discussion in the preceding sections has been concerned with the growth behavior of trees after different kinds of flood damage and after deposition of alluvium around or over the trunk. The form and wood structure of some trees show evidence of a sequence of floods, deposition, and erosion. Study of an ash tree (figs. 19, 28) reveals a complex pattern of wood structure suggesting such a history of alternate deposition and erosion of alluvium around it since the parent trunk was felled during the March 19, 1936, flood. This tree is about 15 feet downstream from the ash tree described on pages 18-23.

The large vertical sprouts (fig. 19) started to grow in 1936 , and since that time about $21 / 2$ feet of sediment has been deposited on the surface around the tree.

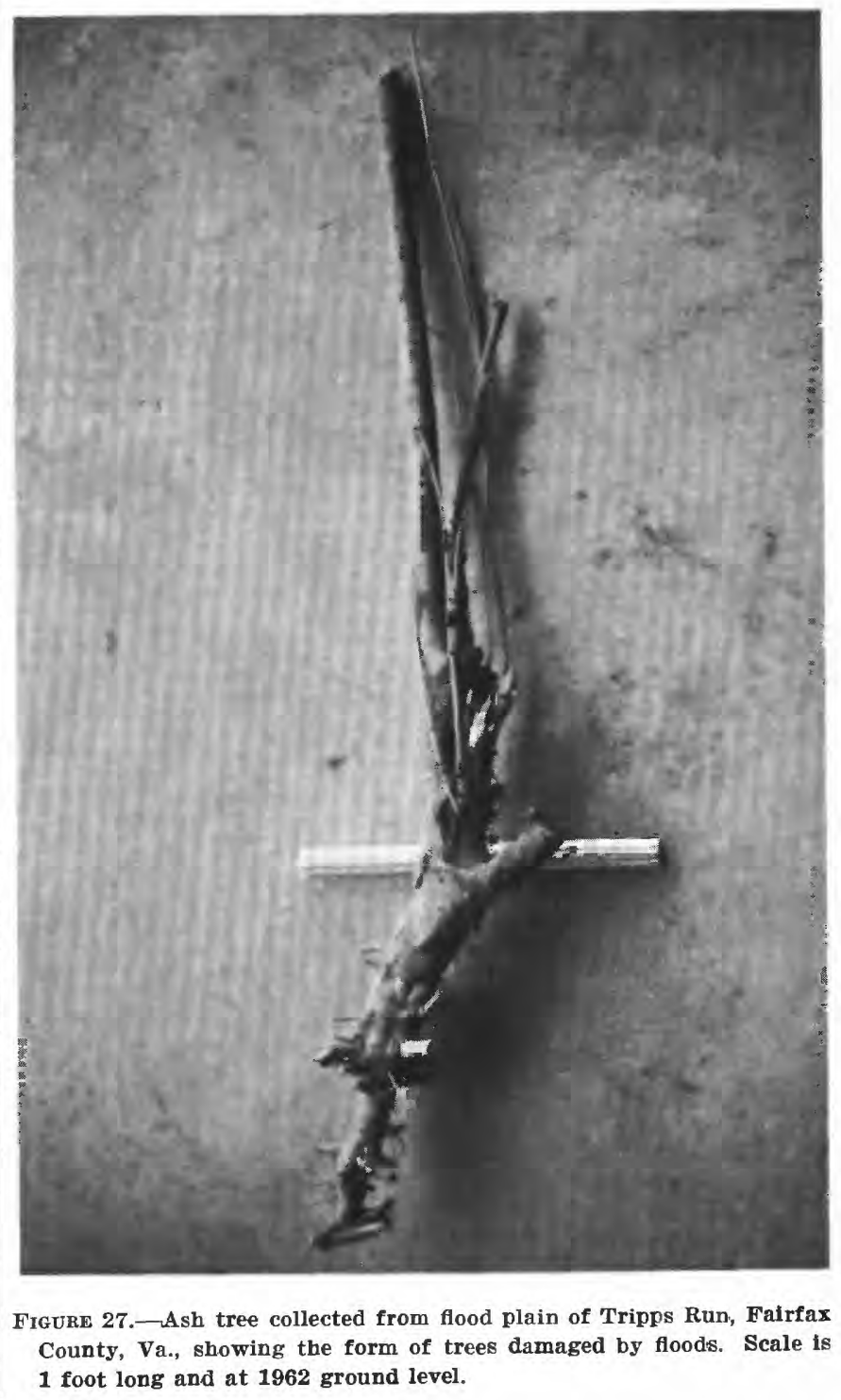




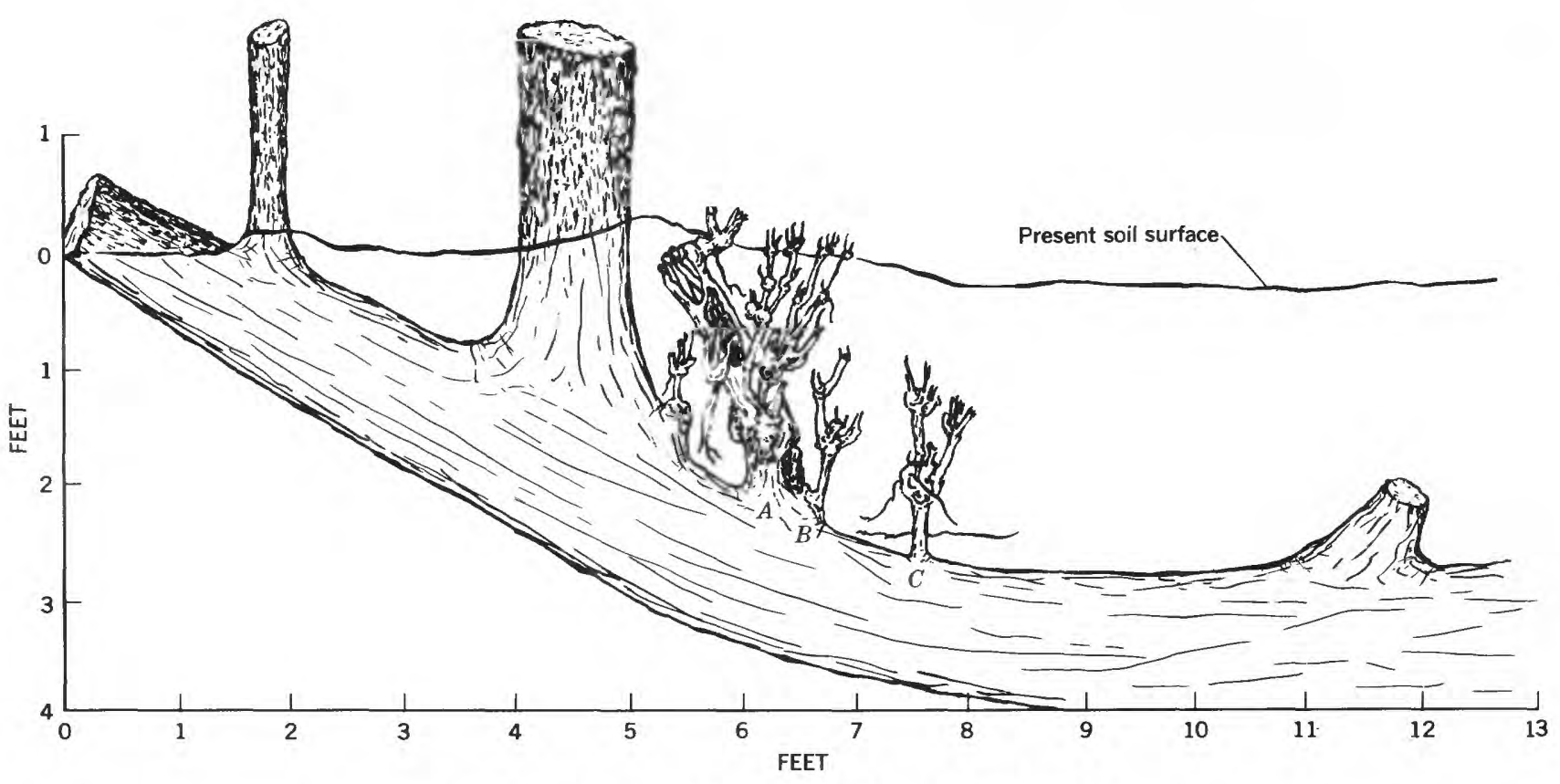

FIGURE 28.-Drawing of buried part of the ash tree in figure 19.

Because sprouts $A, B$, and $C$ (fig. 28) have pith in centers of cross sections through their bases, they must have started to grow as stems. The lower part of sprout $A$ grew above ground for 2 years, became buried, and grew for an indeterminate interval beneath the soil surface; later, it grew above ground for 3 years and then was again buried and continued to grow below the surface until collected. Basal sections through sprouts $B$ and $C$ show similar histories but are not correlative in time. Sections through higher levels in the buried sprouts also show varied wood structure, but their sequences of stem wood and rootlike wood cannot be related to sequences in any other sections. Although these sprouts were alive when collected, the rings in the rootlike wood are indistinct and cannot be dated with certainty; furthermore, it is not known when sprouts $B$ and $C$ started to grow. Their records are; therefore, truncated at the beginning and the end and are obscured in the middle.

Swollen growths at various levels on the buried sprouts from which other sprouts and roots are growing appear to be analagous to root crowns of trees that have been damaged repeatedly (Lutz, 1934, p. 60, fig. 15). There appear to be three levels of these growths, suggesting that three floods cut off the stems at the respective levels and that later floods deposited alluvium over them. Again, it is not possible to date their initial growth.

Although it has been impossible to relate the evidence of deposition and erosion to specific floods, it is evident that this tree has experienced a varied history.
Study of a core from the parent trunk between sprouts $B$ and $C$ indicates that this part of the trunk was buried in 1937 and remained buried until sampled. Another core, taken 1 foot below the surface and to the left of the large vertical sprout in the center of figure 19 , suggests a varied history of sedimentation similar to that of the sections of the small buried sprouts.

In summary, after the tree was felled in 1936, it could have been partly buried in 1937. Later, some floods could have added additional layers of alluvium on top of the 1937 surface, and other floods could have eroded all or part of these layers. Apparently no flood subsequent to the one in 1937 eroded to the pre- 1936 level.

The analysis of the form and the wood structure in the trunk of another tree (fig. 29) is presented as another example of the reconstruction of at least a general history of floods and sedimentation. This tree also grows on the Potomac River flood plain, about 2 miles downstream from Great Falls. The inclined trunk and vertical sprouts show that the tree was knocked over. The roots growing from the fallen trunk show also that the trunk was buried; a small basal sprout, however, attests that the tree was buried during a flood later than the one that felled the tree. Subsequent erosion is confirmed by the exposed roots. The tree was knocked over after the 1942 growing season, probably during the flood of October 17, which was the second highest flood of record. The year of burial cannot be determined from the cores that were taken because some rings cannot be identified; however, 


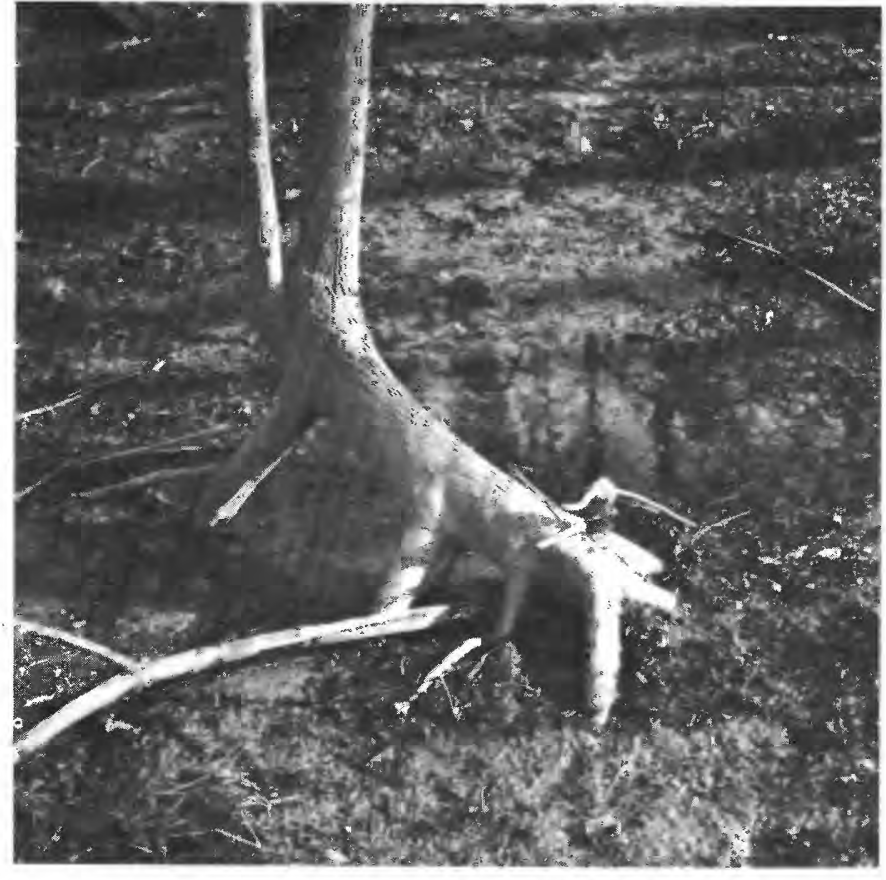

Figure 29.-Ash tree, on flood plain, that was knocked over by one flood, partly buried by another, and exposed by a third.

the fact that alluvium was eroded from around the tree between the growing seasons of 1950 and 1951 can be deduced from a change in wood structure in the fallen trunk between rings of these years. The wood formed in the exposed roots also changed in 1951; wood which has grown since then is more like stem wood. Three floods, on November 26, December 6, and December 10, 1950 , covered the site and could have exposed the roots.

The foregoing detailed description of the tree shown in figure 29, as well as even superficial observations of flood-plain trees, reveals that alluvium is eroded from around roots on flood plains and in channel banks. Wood of ash roots is diffuse-porous, whereas the outer layers of wood in exposed ash roots are ring-porous. The change from diffuse-porous to ring-porous is abrupt and occurs between adjacent rings. This change is attributed to exposure by erosion, and the year of exposure can be determined by counting the rings lying outside the change in wood. Annual rings in the ring-porous wood of exposed roots are distinct.

Detailed study by other investigators has shown anatomical differences between wood of buried roots and wood of exposed roots. Morrison (1953) studied the wood anatomy of roots of six species of trees and found that the length, diameter, and concentration of vessels and the width of rays in exposed roots differed from those in buried roots. Others have found that exposure of lateral roots by erosion results in growth of new wood that is more like that in stems (Bannan, 1962, p. 15; Esau, 1953, p. 512-513).
In review, the botanical evidence of floods, deposition, and erosion consists of the growth of trees after the flood has subsided. This growth manifests itself in the healing of scars on trunks of trees, in the growth of sprouts from inclined trunks, and in the change in wood structure in buried stems and in exposed roots. The growth and change occur during the first growing season after the hydrologic event and can be dated by counting the annual rings that have formed since the change.

\section{BOtaNiCAL PHENOMENA RELATING TO THE FORMATION OF THE FLOOD PLAIN}

The relatively level land bordering a stream, called a valley flat (Twenhofel, 1932, p. 806) or flood plain, is composed of sediments reworked by the river and is subject to flooding (Hoyt and Langbein, 1955, p. 12). The types of deposits that underlie the flood plain have been described by Happ and others (1940, p. 22-25) and by Lattman (1960). Wolman and Leopold (1957 p. 95, 96) have shown that flood plains are formed primarily by the lateral migration of the channel across the valley flat and are thus composed mostly of deposits of lateral accretion. Different definitions of the flood plain exist, but the currently accepted ones seem to agree that a flood plain is the lowland adjoining the channel, subject to flooding, and composed of sediments carried and reworked by the river. Similar differences of opinion in the definition of the river bank exist in the literature, and some authors have expressed difficulty in measuring the height of a river bank (Hack, 1957, p. 48; Schumm, 1961, p. 33; and Wiitala and others, 1961, p. 53). It has been suggested, furthermore, that bankfull floods, which are of intermediate frequency - that is, floods that occur on the average of about once a year or once every 2 years-are more effective in causing the lateral migration of the channel, thus the formation and modification of flood plains, than the larger, less frequent floods (Wolman and Miller, 1960, p. 66).

The sections that follow show that, not only along part of the Potomac River but probably along similar rivers in the East, the channelward limit of flood-plain trees represents the bank. It is a line that can be mapped, and it owes its initial location to the low flow regime of the river. Trees can become established on a flood plain only during extended periods of low flow; yet, once established, they mature and stabilize the banks. The only hydrologic events that remove the trees are the slow lateral undercutting of banks, which causes the trees to topple into the river, and infrequent catastrophic floods. The presence of mature trees along the channel, then, marks the bank; their age 
allows the determination of the frequency, albeit crude, of the reworking of the flood plain deposits by the river.

\section{RELATIONSHIP BETWEEN FLOOD-PLAIN TREES AND LOW FLOW}

A demarcation line readily seen along a stream channel and closely related to the flow regime, as well, is the margin of the perennial vegetation. This line is used to map rivers on topographic maps and, in the humid parts of the United States, coincides with the channelward limit of tree species. The relationship between the flow of rivers and the establishment and growth of trees on the channel banks is only partly understood, because the sequence of events believed necessary for the establishment of trees on banks has not occurred along the main stem of the Potomac River during the period of study; therefore, the conclusions presented here are only tentative.

For trees, or any plants, to become established, three basic elements are necessary: (1) a supply of viable seed, (2) a favorable seed bed, and (3) a period of time during which the environment is favorable for the growth of young plants. Although the yield of tree seed and the time of dissemination are being studied in connection with the larger project, only a few data will be presented here. The time of dissemination, the yield, and a few observations of the fate of silver maple and box elder seed are cited as examples of the relationship of these botanical processes to the flow regime of the river. Behavior of other speciesriver birch, cottonwood, American elm, and sycamore-could be discussed; however, the pattern is similar.

Silver maple trees along the Potomac River near Washington, D.C., drop their seed in late spring, mostly during a 2-week period ending about May 1 . The seed are capable of germinating immediately, and hundreds of newly sprouted ones are seen each May. Seed have been caught and counted in traps and in marked plots on the ground. Over a 4-year period, the number of seed per square yard ranged from 55 to 243 ; and on one day they fell at a rate of 5 per square yard per hour. These data show that an adequate supply of silver maple seed is broadcast on the flood plain.

Box elder seed are disseminated from autumn to early spring; and they, like silver maple seed, are capable of germinating when the weather becomes warm in May, when hundreds of newly sprouted seed of this species are also seen. The number of seed that have fallen annually range from 100 to 250 per square yard.

Although attempts have been made to collect data on the rate of germination of silver maple and box elder seed on different kinds of soil, all quantitative results have been negative. All newly germinated seed and seedlings of these species have been found only on mineral soil, either recently deposited by a flood or recently exposed by erosion of overlying organic matter, or in thin layers of finely comminuted organic flood debris. Some of the seed traps are on the flood plain at levels that have not been inundated during the period of study; therefore, the ground is covered with several years' accumulation of organic matter and leaf litter. Although silver maple and box elder trees are not common near these traps on the higher surfaces, some seed of these species are caught annually. No seedlings of silver maple or box elder, or of any flood-plain tree species, for that matter, have been found on surfaces covered with humus and leaf litter in the 6-year period of observation.

As examples of the fate of seed and seedlings, a series of observations will be discussed. On April 30, 1958,155 newly fallen silver maple seed were counted in a plot having an area of 25 square feet. One week later the plot was inundated by a flood, and the seed were either washed away or buried. None on the plot germinated. On May 16, 1962, 1,150 silver maple seed were counted in five 1-square-yard plots underlain by fine-grained alluvium. These plots were examined periodically, and no seed germinated. On June 21, 1962, numerous new silver maple seedlings were observed outside the plots, but, as late as August, none appeared in the plots. The surface upon which the new seedlings grew, as well as the plots, however, was inundated by floods on March 7 and March 22, 1963, which destroyed the seedlings and deposited 2-4 inches of alluvium on the plots. Environmental conditions at the five marked plots were not favorable for germination, and, as will be seen subsequently, the 1963 floods probably would have destroyed any seedlings if they had germinated.

Seedlings of silver maple and box elder have been found, counted, and observed. Hundreds of silver maple seedlings were found in a small ridge of finely comminuted flood debris on June 8, 1961. In a marked plot extending 6 feet along the ridge and 1 foot across, 228 seedlings were counted. These were destroyed by burial under several inches of sediment on March 23, 1962. Similarly, box elder seedlings were found in two flood-debris ridges in 1958. From late March to late April 1958 the river rose three times, each time to a lower level than before, leaving three debris lines. On May 2, 1958, 64 box elder seedlings were counted in 10 linear feet along the late March line, 13 along the mid-April line, and none along the late April line. A 
few seedlings were growing on the surface between the upper and lower debris lines, and none below the lower line. Because the count was made just 2 days after the late April rise, it seems reasonable to believe that the late April rise destroyed any seedlings that may have germinated on the surface inundated at that time. All seedlings, including those in the higher debris line, were destroyed by the flood of May 7, 1958, which crested at an elevation higher than the late March flood.

In the examples cited, the entire annual crop of seed of silver maple and box elder trees either failed to germinate because the local environmental conditions were not favorable for germination, or the seedlings were destroyed by later floods. For seed of these species to germinate and grow into seedlings and these to become established as a new generation of trees, a new crop of seed must be produced in another year. Because young saplings of all flood-plain tree species are present in the forest along the Potomac River, a sequence of hydrologic events associated with unique climatic conditions must have prevailed in the recent past that has permitted their establishment. This sequence however, did not occur during the period of study.

These data suggest that the orderly sequence of botanical, hydrologic, and as yet unknown environmental events that must prevail before seedlings will become established is as follows: Streamflow during the winter must remove humus and freshly fallen leaf litter from the surface; seed must fall on mineral soil; microclimatic and edaphic conditions must favor germination and growth of seedlings; and finally, the surface must not be flooded again until the seedlings have grown enough to withstand mechanical injury. The interval necessary to insure the trees a chance of survival between seed germination and the first flood is not known, because no floods have recurred during the period of study in areas where young seedlings grow.

Other investigators have noted the orderly sequence of events required for the germination and establishment of plants along rivers. Putnam and others $(1960$, p. 13) found that regeneration of all tree species in southern river valleys will fail if seedlings are repeatedly flooded during the growing season. Dietz (1952, p. 252) observed that, for willows to become established, seed dispersal must occur during the falling stage of a flood, at which time the floating seed are deposited from the receding water in a line on the bank. For seed to germinate, the bank must remain moist; and, for willows, no flood may occur for several months while the seedlings are becoming established. Horton and others (1960) made thorough laboratory,

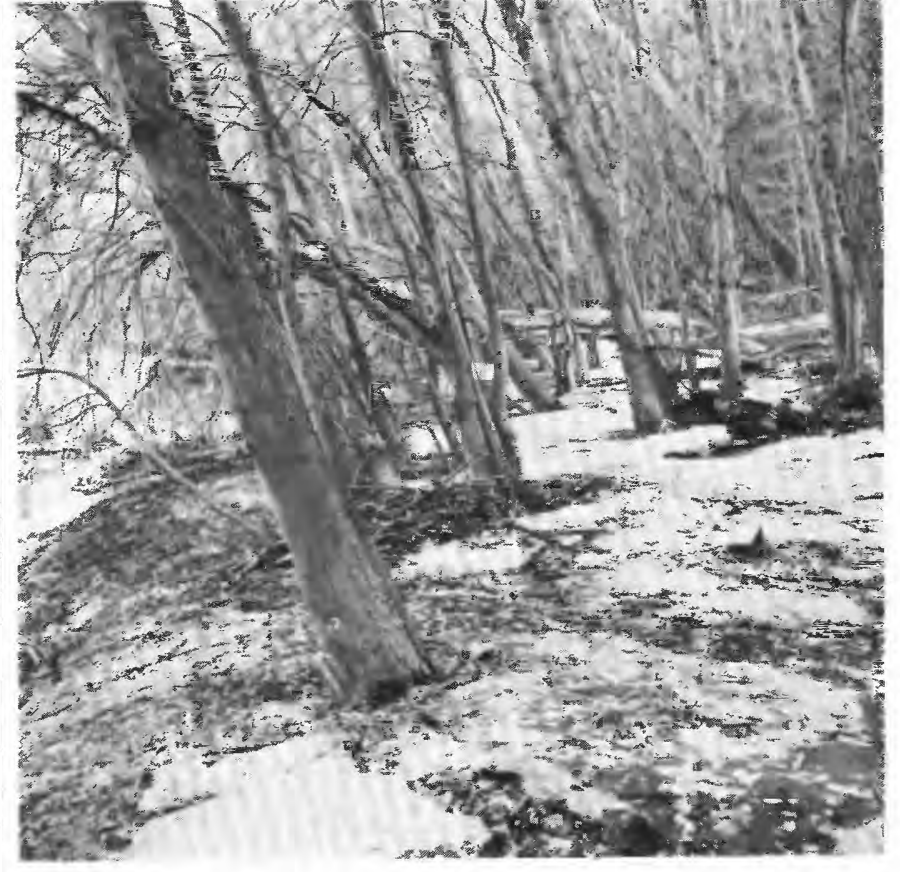

Figure 30.-Mature silver maple trees on low bank that was flooded at least 60 times between 1931 and 1960 . Flow at time of photograph. February 18, 1963, was about 5,000 cfs. Average annual discharge is $11,000 \mathrm{cfs}$. The 2-year flood is about 10 feet deep at this section.

greenhouse, and field studies of seed germination and seedling establishment of riparian species common in the semiarid southwest. They reported (p. 14-16) that tamarisk and seepwillow seed are spread on river banks during receding streamflows in the autumn and winter. If the bank remains moist in early autumn and in spring, many seed will germinate and become established. Both species can survive submergence for as long as several weeks but will be eroded from the soil if subjected to any current. Gardner (1951, p. 398-399) found that seed of creosote bush germinate on exposed gravel bars in the channel of the Rio Grande in New Mexico and that shrubs become established during subsequent dry years.

Mature trees lining long reaches of river banks are inundated as often as several times a year by high flows and by floods. This fact, plus the close relationship between seedling growth and stream hydrology, shows that the establishment and maturation of trees on the bank constitute a botanical process that is adjusted to the low-flow regime of the river. As Leopold and Wolman (1957, p. 63) pointed out, if a river does not use the entire width of the channel, as during periods of low flow, vegetation will quickly occupy the new ground; furthermore, as they stated, growth of vegetation contributes to the deposition of sediment. Shull (1944, p. 776) also noted that several successive years of low water are required for the 
establishment of trees on banks of the Mississippi River. The channelward limit of flood-plain trees, therefore, represents the high-water mark of the maximum stages during periods of low flow (fig. 30).

The surface that is exposed during low flow, upon which trees become established along rivers that slowly migrate laterally, is comparable to a point bar (Leopold, 1962, p. 528; Wolman and Leopold, 1957, p. 91-92). It is initially formed by high flows and floods which also keep it bare, and trees become established across the surface from close to the water's edge only during periods of low flow. The elevation of the surface is raised by deposition during subsequent high flows in a manner similar to that described for point bars in pastures (Wolman and Leopold, 1957, p. 92-93). These processes are represented diagrammatically in figure 31 . The rate of change in point-bar formation in forested flood plains is slower than in pastures.

The deposition of sediment around mature floodplain trees, which occurs during high flows and which was discussed in a previous section, does not adversely affect most trees. The death and destruction of flood-plain trees is more complex, involving internal physiological as well as hydrologic processes related to floodflow; the effects of hydrologic processes upon the development of the forest and formation of flood-plain banks are discussed in the following sections.

\section{SIGNIFICANCE OF OLD TREES ON BANKS}

Detailed mapping of tree species along most of both shores for an approximately 20-mile reach of the Potomac River (fig. 1) indicates that for much of their length these banks are characterized by old trees growing on the vertical face of the bank or, on a few places, on top of it. These banks are, in fact, for most of their length, armored with heavy, old roots, tree bases, and trunks, whose presence indicates that the bank has not changed position for a period equal to at least the age of the trees. The flood-plain deposits, at these places at least, have not been reworked for a long period of time. Leopold and Wolman (1957, p. 69) stated that heavy tree roots bind alluvium of flood plains and that erosion of the banks is extremely slow. They emphasized that the banks of some rivers are not eroded during periods as long as 200 years (Wolman and Leopold, 1957, p. 100).

Active erosion of banks of the Potomac River is manifest in a few places in exposed tree roots, trees leaning over the water, and bare cut banks (fig. 32). Old trees grow on top of these banks. The rate of erosion has not been determined at these places, and at only a few of them would repeated measurements be feasible.

Frequent floods - those that occur on the average of once in two years-do erode the bank in places, undercutting some of the trees and toppling them into the river. Such trees have been observed from time to time in the course of fieldwork. During this period, 1958 to the present, no floods have exceeded the bank at the places where the trees fell into the water. Elsewhere, newly exposed roots are seen extending out from eroded banks after recession of floods (fig. 32).

The presence of many old trees along the banks of the Potomac River suggests that even the catastrophic floods here are no more effective in the erosion of banks and the destruction of the flood-plain forest than are frequent floods. Leopold and Wolman (1957, p. 64) stated that river banks and the trees that grow on them in the Eastern United States are severely eroded only by the larger floods. In mountain streams of the Eastern United States, Hack and Goodlett (1960, p. 48-51) showed that a single catastrophic flood can determine the character of the flood plain, and they believe that forested banks can be moved only by floods of such magnitude. The tree shown in figure 15 is more than 100 years old and has grown on the vertical face of the bank through three major floods which were of sufficient magnitude to be considered catastrophic and which Wolman and Miller (1960, p. 57) suggest recur once in 50 to 100 years. In the vicinity of Washington, D.C., the March 1936 flood has a recurrence interval of about 70 years, and the November 1942 flood, of about 50 years. The third flood to pass over the tree occurred in May and June 1889, prior to the establishment of recording gages on the Potomac River; but it has been estimated as approaching the March 1936 flood in size (Grover, 1937, p. 334).

In addition to these catastrophic floods, the tree (fig. 15) has been inundated by many other floods of lesser magnitude. The flood of May 10, 1960, reached nearly to the level of the base of the sprout and branch above the knife on the smaller tree in the center of the figure. Such a flood has a recurrence interval of 1.9 years; and 18 floods, including those in 1936 and 1942, have equaled or exceeded it in 33 years.

Evidence has been presented which supports the theory that, once the trees become established, they will persist for a long period of time and will coincidentally preserve the location of the bank. The location of the bank, then, is established at a lower elevation close to mean low water and well below the level of floods that recur about once every 2 years. The old trees and the tops of the eroding banks are generally at about the 2-year-flood level. 

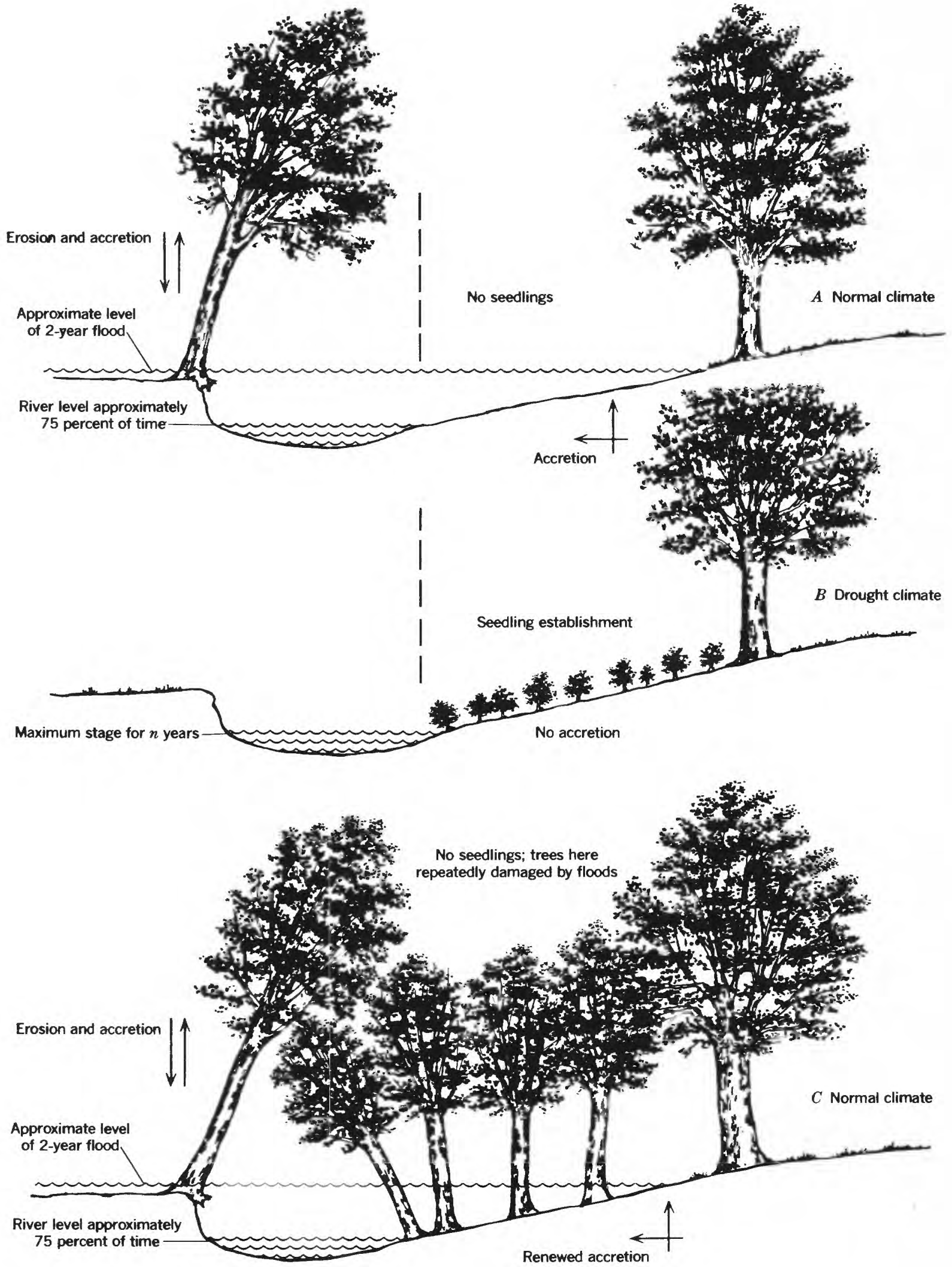

FIGURE 31.-Diagrams representing establishment of trees in relation to the flow regime of the river and the processes modify. ing the flood plain. 


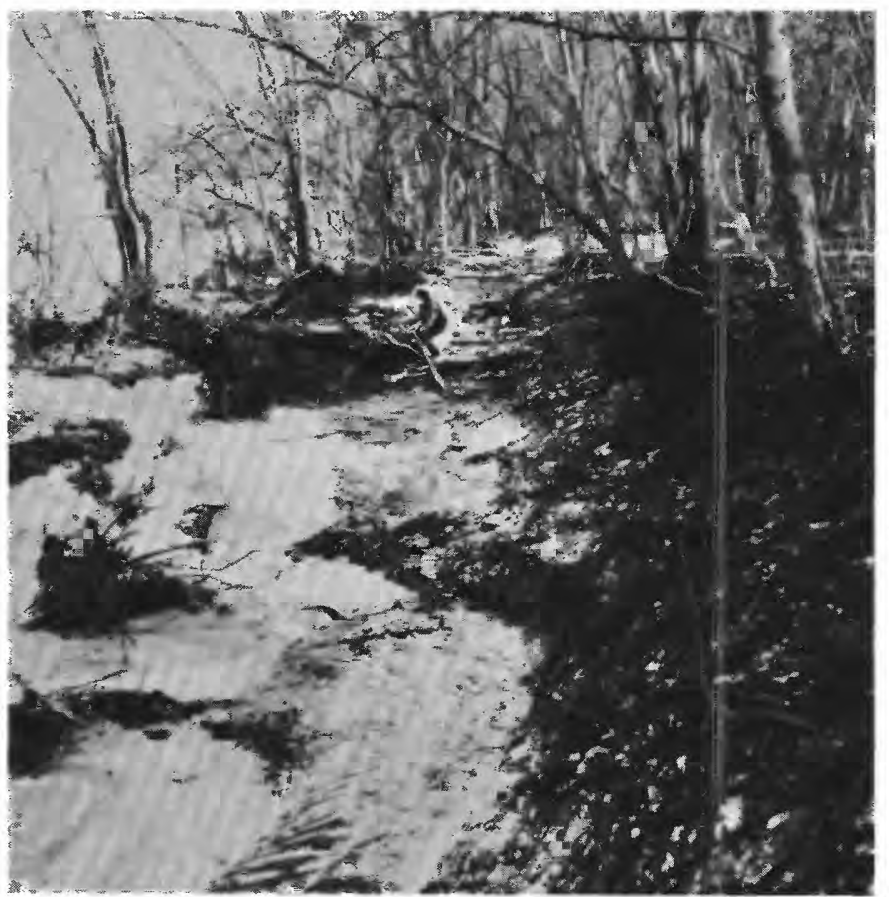

Figure 32.-Cut bank of Potomac River showing newly exposed roots and recently fallen trees. Two-year flood just reaches top of the bank. Area is almost 200 yards upstream from area in flgue 30 .

\section{BOTANICAL EVIDENCE OF CURRENT PROCESSES AFFECTING THE FLOOD PLAIN}

A discussion of the lack of agreement on whether (1) lateral accretion due to point bar deposition, (2) deposition on flood plains in backwater during floods, or (3) erosion and deposition in a sequence of floods makes the major contribution to the deposited sediment is beyond the scope of this report. This controversy, however, fails to note an important aspect shown by the botanical evidence. On some flood plains, certainly on forested ones of rivers that are moving laterally very slowly, local erosion by overbank flows produces rapid interchange of alluvium only to be followed by deposition in flows of comparable magnitude either in the same year or in subsequent years. Flood-plain sediments appear to be constantly reworked to variable depths.

This process of trading of flood-plain materials without intervention of channel movement may affect large amounts of material. It is probably enhanced by vegetation, owing to local concentration of flow, whereas it may be nearly absent on pastured or grassy flood plains. This trading process is shown by botanical evidence to be of greater magnitude than had heretofore been realized, but it probably occurs at this magnitude not only on the Potomac River but also along other eastern rivers of similar character. To the extent that this trading is important the significance of the origin of the first deposited material-lateral deposits or overbank deposits-is proportionately diminished.

Sediment found on the flood plain is not part of the original point bar or overbank deposit; but it is the result of processes-erosion or deposition-that are much more recent than those associated with the initial flood-plain formation. The surface one sees is of relatively recent origin, even if the average elevation of the flood plain has not changed with the passage of time. The flood plain consists of a mosaic of erosional and depositional surfaces in space, and tree form indicates that this sequence is characteristic of any one place at different times. The net effect of this process is temporary storage of alluvium on the flood plain, similar to temporary storage of alluvium in point bars (Wolman and Leopold, 1957, p. 95). The flood plain, its vegetation, and the complete flow regime of the river are elements in dynamic equilibrium with each other (Hack, 1957, p. 90; 1960, p. 85-87; Hack and Goodlett, 1960, p. 58).

The conclusion that banks and flood plains of the Potomac River are eroded only slightly, even by floods having a recurrence interval of 70 years, agrees with the conclusions of Langbein and Schumm (1958). They showed that the annual sediment yield in the United States decreases with an increase in precipitation above about 14 inches per year to a minimum quantity in densely forested regions of the humid East and the Pacific Coast States. Much of the sediment carried by the Potomac River during high flows may well come from scour of its bed (Leopold, 1962, p. 520 ), as well as from erosion throughout the drainage basin (Leopold and Maddock, 1953, p. 21), and, during floods, from erosion of its flood plain.

The concept that vertical erosion and deposition are effective in modifying flood plains in the humid East complements the seemingly opposed concept of predominance of lateral corrasion and deposition. Forested river banks are relatively stable because they are composed of cohesive materials bound by heavy roots (Leopold and Wolman, 1957, p. 64). In the semiarid West, however, river banks, they report, are composed of more friable materials, and flood plains support a less dense plant cover; therefore, these banks are susceptible to erosion by floods of lower magnitude and higher frequency. It follows that the dominant processes that modify a flood plain are determined by the flow regime and the vegetation on the flood plain, as well as by the materials composing the bank. One would expect, therefore, other conditions being equal, that different processes will be dominant in valleys supporting different types of vegetation. Differences 
in the type of vegetation may result from the use of the land by man or from differences in regional climate.

According to this reasoning, change of the natural vegetation due to change in land use or change in climate will result in a change in dominance of processes that act on the flood plain. Upon destruction of the forest on flood plains in the humid East through expansion of urbanization, "improvement" of streams through channelization, or clearing for agriculture, lateral corrasion and deposition will become the dominant processes on the flood plain and will remain so as long as the banks are kept clear of trees. A change in climate to a drier one would result also in an increase in the dominance of lateral corrasion and deposition. This change with change in climate is supported by the conclusions of Langbein and Schumm (1958, p. 1084), who showed that, as conditions change from humid to dry, the sediment load increases, probably as the result of increasing lateral corrasion of the banks.

An interpretation of the botanical phenomena against the background of the flow regime of the river defines the flood plain as the frequently flooded surface adjoining the channel and composed of alluvium deposited and reworked by the river. The bank is the channelward limit of perennial vegetation-tree species in the humid east. The surface is considered to be flooded whenever the level of the river exceeds the bank; and, along the parts of the Potomac River that have been studied, the frequency of these floods ranges from about five times per year to once in 2 years.

In summary, the establishment, growth, maturation, and death of flood-plain trees in humid regions are inseparably merged with the complete flow regime of the river and the erosion and deposition of sediment. The bank, marked by the channelward line of trees, represents the maximum high water line during extended periods of low flow or the margin of the laterally eroding channel. Once the flood-plain trees become established, they will persist through several severe floods. Locally, a few trees are tom out by catastrophic floods, but most die when they reach a maximum size or when they topple into the river as the bank is eroded. Growth of the trees is modified by hydrologic processes resulting in tree forms that record the flood history of the surface.

\section{ECONOMIC SIGNIFICANCE OF BOTANICAL EVIDENCE OF FLOODS}

Some knowledge or undersanding of the magnitude and frequency of floods and flood-plain formation is necessary for the design of structures along rivers and the use of flood plains by man. Some of these structures are flood-control reservoirs, levees, and channels, whose design most obviously must be based in a large part upon the characteristics of floods. The demand for knowledge of floods, needed also to design storm-water drainage systems and to prepare ordinances controlling the use of flood plains, is especially great as a direct result of the seemingly unabated construction of suburban housing. The decisions made to answer the two basic questions underlying any proposal involving streams-is it needed? and, how large should it be? - are influenced, as Langbein and Hoyt (1959, p. 127-142) pointed out, by uncertainties in the hydrologic data.

Some of the uncertainties stem from a complete lack of data from the drainage basin where a project is proposed or from the fact that data have been collected for too short a period of time. About three-fourths of the stream gaging stations in the United States are on streams draining areas larger than 100 square miles, and the total length of small streams greatly exceeds that of larger streams (Langbein and Hoyt, 1959, p. 13-16). Furthermore, about half of the stations have been in operation for less than 20 years.

Botanical evidence of floods and flood-plain deposition discussed in this report will aid in reducing uncertainties. Although the methods are crude and much additional research is needed, a group of fallen trees, a number of partly buried tree trunks, or a tangle of exposed tree roots on a flood plain are positive evidence that something has happened; and further study will reveal the cause of the anomalies in the tree growth. In the section that follows, the value and limitations of botanical evidence are treated as a source of data to extend the records of floods backward in time and to provide a record of events at places where none exists. Finally, the value of botanical evidence of sedimentation is discussed.

\section{VALUE OF BOTANICAL EVIDENCE OF FLOODS AND FLOOD-PLAIN DEPOSITION}

In the absence of flood records, engineers must use indirect methods to determine the frequency of floods of different magnitudes (Jarvis and others, 1936, p. 28-68; Corbett and others, 1945, p. 98-109; Benson, 1962; and Dalrymple, 1960). These methods are estimates of peak flood discharges from which heights of flood crests can be estimated. As Langbein and Hoyt $(1959$, p. 240 ) emphasized, "**** raw hydroloic data are still strange to many $* * *$." Many cannot translate the concept of a flood of a given magnitude and frequency to a mental picture of water flowing down a valley in a broad river, covering the entire flood plain. The methods described in this 
study might provide positive evidence of the occurrence of floods along reaches where the magnitude and frequency are estimated from a minimum of data.

The botanical evidence of floods, consisting of scarred trunks and felled trees, are positive evidence of a catastrophic event. The simple techniques used to analyze this evidence show almost at once when the event occurred. With a little effort a brief history of floods can be developed. At present, however, the evidence is only of the occurrence of a flood. It tells us nothing of the magnitude of the flood except that it exceeded by an appreciable amount the flood that would have just reached the trees. Furthermore, most of the evidence is of the most recent floods and of those that have occurred since the most recent one of catastrophic size. These severe floods, as will be discussed in the following paragraphs, generally remove evidence of earlier ones of lesser magnitude.

All indirect methods of estimating the magnitude and frequency of floods are based on some type of record of hydrologic data, whether it be rainfall or streamflow. Thus, the value of the analysis is dependent upon the record. Dalrymple (1960, p. 13-14) stresses the importance of searching for historical evidence of extreme floods and showed that knowledge of only one flood that exceeded the maximum flood of record lengthens the record back to that historical occurrence.

The botanical evidence of floods discovered in the course of this study has not shown the occurrence of such a flood in the past. Two reasons, it is felt, are responsible for this failure. The maximum flood of record, from 1895 to 1963 , occurred on March 19, 1936. All known historical evidence (Grover, 1937, p. 334; Sanderlin, 1946) indicates that the 1889 flood did not exceed the 1936 flood and the previous maximum flood in 1877 was appreciably smaller than these. Secondly, the floods of 1889 and 1936, as well as the ones in 1937 and 1942 , and the ice jam in 1948, probably destroyed evidence of any possible floods prior to 1877 that could have exceeded the 1936 flood.

The fact that one felled tree has been found that suggests evidence of a flood in 1861 (fig. 15) indicates that an intensive study might reveal botanical evidence of a flood that exceeded the maximum of record, thereby extending the record in time. The probability of finding this evidence in any flood-plain forest is extremely low; and on the Potomac River, where a catastrophic flood occurred 27 years ago, the probability is still lower. For some rivers and streams, however, especially those for which the record is short or for which several kinds of evidence strongly indicate the occurrence of floods many times higher than the highest of record (Stewart and Bodhaine, 1961, p. 25-27), the probability of finding botanical evidence is greater.

Erosion and deposition have been intensively studied by engineers, geologists, soil scientists, biologists, and others for more than 30 years, and even a brief summary of these studies is beyond the scope of this report. Much has been written about accelerated erosion, which is believed by some to be induced by man's use of the land, as opposed to natural erosion; however, doubt exists in the distinction between the two processes and of deposits resulting from them (Strahler, 1956, p. 623). The nature of the problems in measuring erosion quantitatively, summarized by Leopold (1956, p. 639-641), is such that the effect of man's use of the land upon erosion and deposition is most difficult to evaluate. The distinction between deposits laid down under the present climate and those laid down under past climates is difficult to make, and mechanical analysis of samples of some sediments of different origin fails to show significant differences (Hack, 1953, p. 185). Langbein and Hoyt (1959, p. 183-184) emphasized that evidence of accelerated erosion and deposition in valley bottoms is based chiefly on the distinction between modern sediments and the buried "original" soil. They reported that physical and cultural characteristics of the deposits-such as bottles, cans and charcoal layers-are used for separating them. They (p. 184) stressed the need for research in the mechanism of the processes and for long-term observations of erosional and depositional phenomena.

The methods described here provide a means by which the rates of erosion and deposition at specific sites on banks and flood plains can be determined. Other advantages of the study of botanical evidence of floods and sedimentation phenomena are that, within limits, the trees can be studied at a time selected by the researcher and that the trees can contain a record that would otherwise require many decades of observation. Wolman and Eiler $(1958$, p. 8 ) found that after just a few months the sediment deposited by the catastrophic hurricane-Diane floods in August 1955 in New England was difficult if not impossible to distinguish from flood-plain deposits present prior to the floods. As Langbein and Hoyt $(1959$, p. 245) stressed, funds for the collection of basic water facts generally are not appropriated until some crisis stresses the need; thus there is a considerable lag between the need for data and thei availability. Botanical evidence of floods also can reveal evidence of previously unknown historical floods, and thus provide an incentive for a study of other sources for evidence of these floods and of recent floods in places where intense application of indirect 
hydrologic methods would provide an estimate of their magnitude and frequency.

\section{LIST OF PLANTS}

Ash_-_-_---_-----... Fraxinus pennsylvanica

Baldcypress_-_-_-_-_. Taxodium distichum

Marshall

Birch, river

(Linneaus) Richardson

Boxelder Betula nigra Linneaus

Cottonwood. Acer negundo Linneaus

Elm, American Populus deltoides Bartram

Maple, silver Ulmus americana Linneaus

Acer saccharinum Linneaus

Oak, swamp white_... Quercus bicolor Willdenow

Sycamore_-..-_-_.-.. Platanus occidentalis Linneaus

Tupelo-_--_-_-_---- Nyssa sylvatica Marshall

Walnut, black _....... Juglans nigra Linneaus

Willow Salix Linneaus

\section{REFERENCES CITED}

Bannan, W. M., 1962, The vascular cambium and tree-ring development, in Kozlowski, T. T., Tree growth: New York, Ronald Press, p. 1-21.

Beakbane, A. B., 1941, Anatomical studies of stems and roots of hardy fruit trees, III, The anatomical structure of some clonal and seedling apple root stocks, stem and root grafted with a scion variety: Jour. Pomology and Horticultural Sci., v. 18, p. 344-367.

Benson, M. A., 1962a, Evolution of methods for evaluating the occurrence of floods: U.S. Geol. Survey Water-Supply Paper 1580-A, 30 p.

1962b, Factors influencing the occurrence of fioods in a humid region of diverse terrain: U.S. Geol. Survey Water-Supply Paper 1580-B, 64 p.

Brown, H. P., Panshin, A. J., and Forsaith, C. C., 1949, Textbook of wood technology: New York, McGraw-Hill, v. 1, 652 p. ; v. 2,783 p.

Corbett, D. M., and others, 1945, Stream-gaging procedures : U.S. Geol. Survey Water-Supply Paper 888, 245 p.

Cribbs, J. E., 1917, Plant associations of western Pennsylvania with a special reference to physiographic relationship: Plant World, v. 20, p. 97-120, 142-157.

Dalrymple, Tate, 1960, Flood-frequency analyses: U.S. Geol. Survey Water-Supply Paper 1543-A, 80 p.

Darling, J. M., 1959, Floods in Maryland magnitude and frequency : U.S. Geol. Survey open-file report, 9 p.

Dietz, R. A., 1952, The evolution of a gravel bar: Missouri Bot. Garden Annals, v. 39, p. 249-254.

Dore, W. G., and Gillett, J. M., 1955, Botanical survey of the St. Lawrence seaway area in Ontario: Ottawa, Ontario, Canada Dept. Agriculture, Botany and Plant Pathology Div., Sci. Serv., 115 p.

Eames, A. J., and MacDaniels, L. H., 1947, An introduction to plant anatomy : New York, McGraw-Hill, 427 p.

Eisenlohr, W. S., Jr., 1952, Floods of July 18, 1942, in north-central Pennsylvania: U.S. Geol. Survey WaterSupply Paper 1134-B, p. 59-158.
Esau, Katherine, 1953, Plant anatomy : New York, John Wiley \& Sons, 735 p.

1960, Anatomy of seed plants: New York, John Wiley \& Sons, $376 \mathrm{p}$.

Featherly, H. I., 1941, Silting and forest succession on Deep Fork in Southwestern Creek County, Oklahoma : Oklahoma Acad. Sci. Proc., v. 21, p. 63-64.

Ferguson, G. E., 1942, Gage to measure crest stages of streams : Civil Eng., v. 12, p. 570-571.

Gardner, J. L., 1951, Vegetation of the creosote bush area of the Rio Grande valley in New Mexico: Ecol. Mon., v. 21, p. 379-403.

Gates, F. C., and Woollett, E. C., 1926, The effect of inundation above a beaver dam upon upland vegetation: Torreya, $\mathbf{v}$. 26, p. $45-50$.

Glock, W. S., Studhalter, R. A., and Agerter, S. R., 1960, Classification and multiplicity of growth layers in the branches of trees: Washington, D.C., Smithsonian Inst. Pub. 4421, $292 \mathrm{p}$.

Grater, R. K., 1947, Memorandum to the Superintendant, Kautz Creek Flood: Mt. Rainier National Park Naturalist Files, Longmire, Washington.

- 1948, The fiood that swallowed a glacier : Nat. History, v. 57 p. $276-280$.

Grover, N. C., 1937, The floods of March 1936, Part 3, Potomac, James and upper Ohio Rivers: U.S. Geol. Survey WaterSupply Paper 800, 351 p.

Hack, J. T., 1953, Geologic evidence of late Pleistocene climates, in Shapley, Harlow, 1953, Climatic change evidence, causes, and effects: Cambridge, Mass., Harvard Univ. Press, p. 179-188.

1957, Longitudinal stream profiles in Virginia and Maryland : U.S. Geol. Survey Prof. Paper 294-B, p. 45-97.

- 1960, Interpretation of erosional topography in humid temperate regions: Am. Jour. Sci., v. 258-A, p. 80-97.

Hack, J. T., and Goodlett, J. C., 1960, Geomorphology and forest ecology of the mountain region of central Appalachians: U.S. Geol. Survey Prof. Paper 347, 66 p.

Hadley, R. F., 1960, Recent sedimentation and erosional history of Fivemile Creek, Fremont County, Wyoming: U.S. Geol. Survey Prof. Paper 352-A, p. 1-16.

Hall, T. F., and Smith, G. E., 1955, Effects of flooding on woody plants, West Sandy dewatering project, Kentucky Reservoir: Jour. Forestry, v. 53, p. 281-285.

Happ, S. C., Rittenhouse, Gordon, and Dobson, G. C., 1940, Some principles of accelerated stream and valley sedimentation: U.S. Dept. Agriculture Tech. Bull. 695, 133 p.

Harper, H. J., 1938, Effect of silting on tree development in the fiood plain of Deep Fork of the North Canadian River in Creek Co.: Oklahoma Acad. Sci. Proc., v. 18, p. 46-49.

Horton, J. S., Mounts, F. C., and Kraft, J. M., 1960, Seedling germination and seedling establishment of phreatophyte species: U.S. Forest Service Rocky Mountain Forest and Range Expt. Sta. Paper 48, 25 p.

Hoyt, W. G., and Langbein, W. B., 1955, Floods : Princeton, N.J., Princeton Univ. Press, 469 p.

Jahns, R. H., 1947, Geologic features of the Connecticut valley, Massachusetts, as related to recent floods: U.S. Geol. Survey Water-Supply Paper 996, 158 p.

Jarvis, C. S., and others, 1936, Floods of the United States, magnitude and frequency: U.S. Geol. Survey Water-Supply Paper 771, $497 \mathrm{p}$.

Johnstone, Don, and Cross, W. P., 1949, Elements of applied hydrology : New York, Ronald Press, 276 p. 
Koehler, Arthur, 1933, Causes of brashness in wood : U.S. Dept. Agriculture Tech. Bull. 342, 40 p.

Kramer, P. J., and Kozlowski, T. T., 1960, Physiology of trees : New York, McGraw-Hill, 642 p.

Langbein, W. B., and Hoyt, W. G., 1959, Water facts for the nation's future: New York, Ronald Press, $288 \mathrm{p}$.

Langbein, W. B., and Schumm, S. A., 1958, Yield of sediment in relation to mean annual precipitation: Am. Geophys. Union Trans., v. 39, p. 1076-1084.

Lattman, L. H., 1960, Cross section of a flood plain in a moist region of moderate relief: Jour. Sed. Petrology, v. 30, p. 275-282.

Leopold, A. C., 1955, Auxins and plant growth: Berkeley, Univ. of California Press, 354 p.

Leopold, L. B., 1953, Downstream change in velocity of rivers : Am. Jour. Sci., v. 251, p. 606-624.

1956, Land use and sediment yield, in Thomas, W. L., ed., Man's role in changing the face of the earth: Chicago, IIl., Univ. of Chicago Press, p. 639-647.

1962, Rivers : Am. Scientist, v. 50, p. 511-537.

Leopold, L. B., and Maddock, Thomas, Jr., 1953, The hydraulic geometry of stream channels and some physiographic implications : U.S. Geol. Survey Prof. Paper 252, 57 p.

1954, The flood control controversy: New York, Ronald Press, 278 p.

Leopold, L. B., and Wolman, M. G., 1957, River channel patterns-braided, meandering, and straight: U.S. Geol. Prof. Paper 282-B, p. 39-85.

Lindsey, A. A., Petty, R. O., Sterling, D. K., and Van Asdall, Willard, 1961, Vegetation and the environment along the Wabash and Tippecanoe Rivers: Ecol. Mon., v. 31, p. 105156.

Linsley, R. K., Jr., Kohler, M. A., and Paulhus, J. L. 1958, Hydrology for engineers : New York, McGraw-Hill, $340 \mathrm{p}$.

Little, E. L., Jr., 1953, Check list of native and naturalized trees of the United States: U.S. Dept. Agriculture Handb. 41, $472 \mathrm{p}$.

Lutz, H. J., 1934, Ecological relations in the pitch pine plains of southern New Jersey: Yale Univ. School of Forestry Bull. 38, 80 p.

Morrison, T. M., 1953, Comparative histology of secondary xylem in buried and exposed roots of dicotyledonous trees : Phytomorphology, v. 3, p. 427-430.

Pillow, M. Y., 1939, Characteristics of ash from. southern bottomlands: Southern Lumberman, Dec. 15, p. 131-136.

Putman, J. A., Furnival, G. M., and McKnight, J. S., 1960, Management and inventory of southern hardwoods: U.S. Dept. Agriculture Handb. 181, 102 p.

Reed, J. F., 1952, The vegetation of the Jackson Hole Wildlife Park, Wyoming: Am. Midland Nat., v. 48, p. 700-729.

Sanderlin, W. S., 1946, The great national project: Baltimore, Md., Johns Hopkins Univ. Studies in Historical and Political Sci., ser. 64, no. 1, 331 p.
Schumm, S. A., 1961, Effect of sediment characteristics on erosion and deposition in ephemeral stream channels : U.S. Geol. Survey Prof. Paper 352-C, p. 31-70.

Shull, C. A., 1922, The formation of a new island in the Mississippi River : Ecology, v. 3, p. 202-206.

- 1944, Observations of general vegetational changes on a river island in the Mississippi River: Am. Midland Nat., v. 32, p. 771-776.

Sigafoos, R. S., 1961, Vegetation in relation to flood frequency near Washington, D.C., in Geological Survey Research 1961 : U.S. Geol. Survey Prof. Paper 424-C, p. C248-C250.

Silker, T. H., 1948, Planting water tolerant trees along margins of fluctuating level reservoirs: Iowa State Coll. Jour. Sci., v. 22, p. 431-438.

Stewart, J. E., and Bodhaine, G. L., 1961, Floods in the Skagit River basin, Washington: U.S. Geol. Survey Water-Supply Paper 1527, $66 \mathrm{p}$.

Strahler, A. N., 1956, The nature of induced erosion and aggradation, in Thomas, W. L., Jr., ed., Man's role in changing the face of the earth: Chicago, Ill., Univ. of Chicago Press, p. 621-638.

Turner, L. M., 1930, The 1926-27 floods and the Illinois River valley vegetation: Illinois Acad. Sci. Trans., v. 22, p. 95-97.

1936, Ecological studies in the lower Illinois River valley : Bot. Gaz., v. 97, p. 689-727.

Twenhofel, W. H., 1932, Treatise on sedimentation: Baltimore, Md., William and Wilkins, $926 \mathrm{p}$.

Ware, G. H., and Penfound, W. T., 1949, The vegetation of the lower levels of the floodplain of the South Canadian River in central Oklahoma: Ecology, v. 30, p. 478-484.

Water Resources Branch, 1949, Floods of August 1940 in the southeastern states: U.S. Geol. 'Survey Water-Supply Paper 1066, $554 \mathrm{p}$.

Water Resources Division, 1964, Summary of floods in United States during 1956: U.S. Geol. Survey Water-Supply Paper $1530,85 \mathrm{p}$.

Wiitala, S. W., Jetter, K. R., and Somerville, A. J., 1961, Hydraulic and hydrologic aspects of flood-plain planning: U.S. Geol. Survey Water-Supply Paper 1526, 69 p.

Wistendahl, W. A., 1958, The flood plain of the Raritan River, New Jersey : Ecol. Mon., v. 28, p. 129-153.

Wolman, M. G., and Eiler, J. P., 1958, Reconnaissance study of erosion and deposition produced by the flood of August 1955 in Connecticut: Am. Geophys. Union Trans., v. 39, p. 1-14.

Wolman, M. G., and Leopold, L. B., 1957, River flood plains : some observations on their formation: U.S. Geol. Survey Prof. Paper 282-C, p. 87-109.

Wolman, M. G., and Miller, J. P., 1960, Magnitude and frequency of forces in geomorphic processes: Jour. Geology, v. 68 , p. 54-74.

Yeager, L. E., 1949, Effect of permanent flooding in a riverbottom timber area: Illinois Nat. History Survey Bull., v. 25, p. 33-65. 